\title{
"Live" (stained) benthic foraminiferal living depths, stable isotopes, and taxonomy offshore South Georgia, Southern Ocean: implications for calcification depths
}

\author{
Rowan Dejardin $^{1}$, Sev Kender ${ }^{2,3}$, Claire S. Allen ${ }^{4}$, Melanie J. Leng ${ }^{1,5}$, George E. A. Swann ${ }^{1}$, and \\ Victoria L. Peck ${ }^{4}$ \\ ${ }^{1}$ Centre for Environmental Geochemistry, School of Geography, University of Nottingham, University Park, \\ Nottingham, NG7 2RD, UK \\ ${ }^{2}$ Camborne School of Mines, University of Exeter, Penryn, Cornwall TR10 9FE, UK \\ ${ }^{3}$ British Geological Survey, Keyworth, Nottingham NG12 5GG, UK \\ ${ }^{4}$ British Antarctic Survey, High Cross, Madingley Road, Cambridge, CB3 0ET, UK \\ ${ }^{5}$ NERC Isotope Geosciences Facilities, British Geological Survey, Keyworth, Nottingham, NG12 5GG, UK
}

Correspondence: Rowan Dejardin (rowan.dejardin@nottingham.ac.uk)

Published: 5 January 2018

\begin{abstract}
It is widely held that benthic foraminifera exhibit species-specific calcification depth preferences, with their tests recording sediment pore water chemistry at that depth (i.e. stable isotope and trace metal compositions). This assumed depth-habitat-specific pore water chemistry relationship has been used to reconstruct various palaeoenvironmental parameters, such as bottom water oxygenation. However, many deepwater foraminiferal studies show wide intra-species variation in sediment living depth but relatively narrow intra-species variation in stable isotope composition. To investigate this depth-habitat-stable-isotope relationship on the shelf, we analysed depth distribution and stable isotopes of "living" (Rose Bengal stained) benthic foraminifera from two box cores collected on the South Georgia shelf (ranging from 250 to $300 \mathrm{~m}$ water depth). We provide a comprehensive taxonomic analysis of the benthic fauna, comprising 79 taxonomic groupings. The fauna shows close affinities with shelf assemblages from around Antarctica. We find "live" specimens of a number of calcareous species from a range of depths in the sediment column. Stable isotope ratios $\left(\delta^{13} \mathrm{C}\right.$ and $\delta^{18} \mathrm{O}$ ) were measured on stained specimens of three species, Astrononion echolsi, Cassidulinoides porrectus, and Buccella sp. 1, at $1 \mathrm{~cm}$ depth intervals within the downcore sediment sequences. In agreement with studies in deep-water settings, we find no significant intra-species variability in either $\delta^{13} \mathrm{C}_{\text {foram }}$ or $\delta^{18} \mathrm{O}_{\text {foram }}$ with sediment living depth on the South Georgia shelf. Our findings add to the growing evidence that infaunal benthic foraminiferal species calcify at a fixed depth. Given the wide range of depths at which we find "living", "infaunal" species, we speculate that they may actually calcify predominantly at the sediment-seawater interface, where carbonate ion concentration and organic carbon availability is at a maximum.
\end{abstract}

\section{1}

Benthic foraminifera live both on (epifaunal) and beneath (infaunal) the sediment-seawater interface, and their assemblages and stable isotope and trace element compositions are widely utilized as tools in the reconstruction of past oceanographic conditions (see review in Jorissen et al., 2007). Stable isotopes of all species typically exhibit inter-species off- sets. In part this offset is accounted for by "vital effects", inter-species differences in the fractionation of stable isotopes due to a range of biological factors (see review in Ravelo and Hillaire-Marcel, 2007). Another consideration, adopted in numerous studies, is that epifaunal and infaunal inter-species isotopic offsets reflect, in part, pore water chemistry at the preferred depth habitat of each species within the sediment (e.g. Loubere et al., 1995; McCorkle et 
al., 1997; Theodor et al., 2016). The carbon isotope composition of pore water dissolved inorganic carbon $\left({ }^{13} \mathrm{C}_{\mathrm{DIC}}\right)$ has been shown to become lighter (lower $\delta^{13} \mathrm{C}$ ) with sediment depth (e.g. McCorkle et al., 1985), due to the remineralization (by oxic respiration or denitrification) of organic carbon. The difference between bottom and pore water $\delta^{13} \mathrm{C}_{\text {DIC }}$ has been shown to increase with bottom water oxygenation (McCorkle and Emerson, 1988). Assuming that infaunal species calcify at preferred depths within the sediment hypothetically allows $\delta^{13} \mathrm{C}_{\text {DIC }}$ gradients to be reconstructed through the isotope analysis of paired epifaunal and deep-infaunal taxa (e.g. Cibicidoides wuellerstorfi and Globobulimina spp.; Hoogakker et al., 2015). Similarly, the difference in $\delta^{13} \mathrm{C}$ between epifaunal and shallow infaunal species (e.g. Uvigerina spp.) has been used to reconstruct the intensity of organic matter remineralization, a proxy for the flux of organic matter to the sea floor (Zahn et al., 1986; McCorkle and Emerson, 1988; Schilman et al., 2003). Additionally, Elderfield et al. (2012) used the presence of a constant offset between the $\delta^{13} \mathrm{C}$ data from paired epifaunal (Cibicidoides wuellerstorfi) and infaunal (Uvigerina spp.) foraminifera to negate the suggestion that a negative $\delta^{13} \mathrm{C}$ excursion during Marine Isotope Stage 22 was due to productivity changes and to support their hypothesis that the $\delta^{13} \mathrm{C}$ excursion was instead related to global ocean change.

These applications rely on the previously stated assumption that benthic foraminifera inhabit species-specific depth habitats and, more importantly, calcify at that depth, thereby recording the pore water $\delta^{13} \mathrm{C}_{\mathrm{DIC}}$ gradient. This assumption is held despite the wide range of sediment depths that individual infaunal species have been observed to live at (e.g. McCorkle et al., 1997). Furthermore, isotope analysis of "live" (Rose Bengal stained) foraminifera reveals a narrow range of isotope values for individuals of the same species despite them having been recovered from a wide range of depths beneath the sediment surface (McCorkle et al., 1990, 1997; Schmiedl et al., 2004; Fontanier et al., 2006b, 2008; Theodor et al., 2016). A narrow intra-species range of $\delta^{13} \mathrm{C}$ composition of "live" specimens recovered from a range of sediment depths argues against individuals having calcified at the depths from which they were recovered (since pore water $\delta^{13} \mathrm{C}_{\mathrm{DIC}}$ gradients are not reflected in the foraminifera). More recent studies raise further questions about the validity of the assumed calcification depths of infaunal species. For example, it has been assumed that $\mathrm{Mg} / \mathrm{Ca}$ data from infaunal foraminifera are relatively insulated from the effect of bottom water $\left[\mathrm{CO}_{3}^{2-}\right.$ ] changes (Elderfield et al., 2006, 2010). However, Weldeab et al. (2016) have shown that infaunal Globobulimina spp. are sensitive to changes in bottom water $\left[\mathrm{CO}_{3}^{2-}\right]$, implying that calcification may not occur exclusively beneath the sediment surface. To extend previous studies of the deep ocean (e.g. McCorkle et al., 1990, 1997; Tachikawa and Elderfield, 2002; Schmiedl et al., 2003; Fontanier et al., 2008, 2006b) onto the shelf environment, and test the assumption that infaunal species calcify at pre- ferred depths and that their $\delta^{13} \mathrm{C}$ composition is reflective of pore water $\delta^{13} \mathrm{C}_{\text {DIC }}$ (i.e. decreasing $\delta^{13} \mathrm{C}_{\text {DIC }}$ with increasing calcification depth), we measured the living depths and isotope composition of three as yet unstudied species (Astrononion echolsi, Cassidulinoides porrectus, and Buccella sp. 1) from the South Georgia shelf, South Atlantic. We also report the depth ranges of all "living" (Rose Bengal stained) benthic foraminifera. To underpin these and future analyses, we carried out a detailed taxonomic analysis of benthic foraminifera from six surface samples, two box-core downcore sequences, and two gravity cores, the first such study focused on South Georgia since Earland (1933).

\subsection{Previous benthic foraminiferal studies}

Earland (1933) conducted a survey of the benthic foraminifera of South Georgia, utilizing surface sediment samples collected from around the island as part of the Discovery expeditions. Since this study, there has been no further taxonomic work focussed on South Georgia, but a number of benthic foraminiferal assemblage studies have been conducted at other Southern Ocean and Antarctic locations. The Antarctic Peninsula is one of the better-studied areas in the region, with foraminiferal research here commencing in the first half of the 20th century (Earland, 1934; Cushman, 1945), followed by a number of brief US Antarctic Program taxonomic reports (e.g. Lipps et al., 1972). In a more comprehensive study of the Antarctic Peninsula, Ishman and Domack (1994) analysed a large number of surface sediment samples from three areas on the western side of the peninsula (Bransfield Strait, Marguerite Bay, and Palmer Archipelago). A detailed assessment of the benthic foraminiferal assemblages of Admiralty Bay, King George Island, and the South Shetland Islands has been conducted by Majewski $(2005,2010)$, again on surface sediment samples. On the eastern side of the Antarctic Peninsula, Majewski and Anderson (2009) examined the palaeoclimatic implications of Holocene foraminiferal assemblages from the Firth of Tay. Further east, Anderson (1975) identified 160 species in surface samples distributed across the Weddell Sea, whilst Mackensen et al. (1990) focussed on surface samples from the sea's eastern corner.

Herb (1971) described the variation in benthic faunas across the Drake Passage, illustrating the differences between the shelf environments of southern South America and Antarctica. Mackensen et al. (1993) analysed a similar transect of surface samples through the subantarctic zone between 0 and $10^{\circ} \mathrm{E}$. Useful studies from Southern Ocean localities more distant from South Georgia include Majewski's (2013) description of benthic foraminifera from coretop samples around Pine Island and Ferrero Bays in the Amundsen Sea, Violanti's (1996) analysis of live and dead foraminifera from surface samples from Terra Nova Bay, Ross Sea, and Igarashi et al.'s (2001) study of samples from 


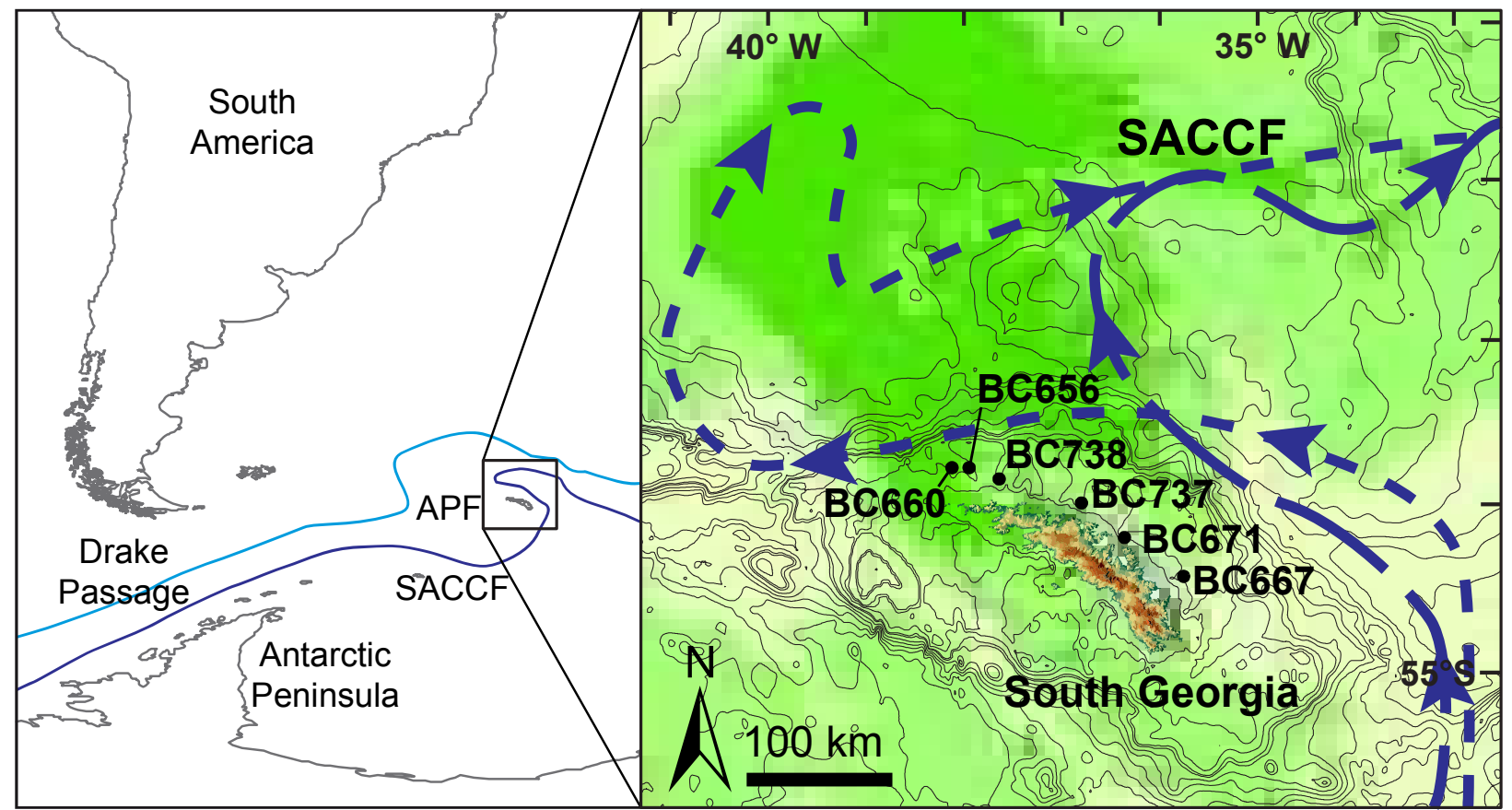

Figure 1. Map of South Georgia and sampling locations. The location of South Georgia in relation to the Antarctic Peninsula and South America showing the approximate location of the Antarctic Polar Front (APF - light blue) and the Southern Antarctic Circumpolar Current Front (SACCF - dark blue). The inset and map on the left show a topographical map of South Georgia and surrounding bathymetry with the sampling locations indicated. The dark blue lines represent the location and average position of the SACCF (contemporary variation near South Georgia shown by the dashed lines, indicating most easterly and westerly extents (Thorpe et al., 2002). The mean surface chlorophyll$\alpha$ concentration $\left(\mathrm{mg} \mathrm{m}^{-2}\right.$ ) between September and March is shown in green with darker colours indicating higher concentration (SeaWiFS derived satellite data, NASA; means calculated only for cells where 10 values were obtained within a year; from Murphy et al., 2013).

sediment cores extending into the Holocene from LützowHom Bay, East Antarctica.

\subsection{Oceanographic setting}

The subantarctic island of South Georgia $\left(54^{\circ} \mathrm{S}, 36^{\circ} \mathrm{W}\right)$ is located at the northern edge of the Scotia Sea in the path of the Antarctic Circumpolar Current (ACC), between the Antarctic Polar Front (APF) and the Southern ACC Front (SACCF) (Fig. 1). South Georgia is one of the largest islands in the subantarctic zone (SAZ), measuring approximately $180 \times 40 \mathrm{~km}$, and is separated from the deep ocean by a $50-150 \mathrm{~km}$ wide continental shelf. The shelf, typically within 200-250 $\mathrm{m}$ water depth, is traversed by canyons that connect the island's fjords to the continental slope. The properties of the waters of the shelf itself routinely differ from those of the surrounding ocean, with on-shelf surface waters typically being warmer $\left(2-3^{\circ} \mathrm{C}\right.$ on shelf, $1.5-2^{\circ} \mathrm{C}$ off shelf $)$ and fresher (salinity 33.4-33.7 psu on shelf, 33.6-33.7 psu off shelf) (Brandon et al., 1999). These differences are caused by a number of shelf-specific processes, such as freshwater run-off and topographically steered circulation (Brandon et al., 1999, 2000; Meredith et al., 2005).

\section{Methods}

\subsection{Sample acquisition and preparation}

Two box cores (BC737 and BC738) were collected during British Antarctic Survey scientific cruise JR-15002, in November 2015 (see Table 1 and Fig. 1), from which two sub-cores were collected (BC737 (D) and BC738 (D)). The box cores were collected using the British Antarctic Survey (BAS) box corer, deployed from the RRS James Clark Ross. The sub-cores were taken from BC737 $(15 \mathrm{~cm})$ and BC738 $(20 \mathrm{~cm})$; these cores were cut into $1 \mathrm{~cm}$ sections which were weighed to the nearest gram before being washed over a $63 \mu \mathrm{m}$ sieve. The coarse fraction was then soaked in a Rose Bengal / seawater solution (1 $\mathrm{g}: 1 \mathrm{~L})$ for $24 \mathrm{~h}$ before being rinsed with seawater from the underway seawater supply until the water ran clear and dried at $40^{\circ} \mathrm{C}$ after a final rinse with MilliQ water. Rose Bengal is a non-vital biological stain that is adsorbed onto any proteins, whether or not they are alive, and can therefore stain necrotic as well as healthy cytoplasm (Bernhard, 2000). 
Table 1. Sample locations.

\begin{tabular}{lrrrl}
\hline Core no. & Latitude & Longitude & Water depth $(\mathrm{m})$ & Sample \\
\hline BC656 & -53.78168 & -37.95855 & 303 & Surface sample \\
BC660 & -53.78188 & -38.12847 & 354 & Surface sample \\
BC667 & -54.42063 & -35.74152 & 252 & Surface sample \\
BC671 & -54.20237 & -36.37451 & 239 & Surface sample \\
BC737 & -53.99709 & -36.82012 & 260 & Surface sample \\
BC737 (D) & -53.99709 & -36.82012 & 260 & 15 cm sub-core \\
BC738 & -53.85504 & -37.65095 & 287 & Surface sample \\
BC738 (D) & -53.85504 & -37.65095 & 287 & 20 cm sub-core \\
GC666* & -54.4206 & -35.74148 & 253 & 815 cm gravity core \\
GC673* & -54.20237 & -36.37451 & 238 & $884 \mathrm{~cm}$ gravity core \\
\hline
\end{tabular}

* Samples with foram species not present in the box cores are included in Sect. 6 and Supplement.

\subsection{Benthic foraminiferal assemblage analysis}

All "living" (stained) and dead foraminifera were dry picked from each of the $1 \mathrm{~cm}$ samples between 0 and $10 \mathrm{~cm}$, and only "living" (stained) foraminifera were dry picked from each of the $1 \mathrm{~cm}$ samples between 10 and $13 \mathrm{~cm}$, from $\mathrm{BC} 737$ and BC738. Tests where all, or all but one or two, chambers were well stained bright red were considered to be "living" at the time of staining (e.g. Caulle et al., 2015; Fontanier et al., 2016; Wang et al., 2016). For thick-walled agglutinated taxa, where the opaque test wall concealed the extent of the staining, the tests were broken open allowing the staining to be assessed. Tests with a pink tint or isolated spots of red were not included, nor were tests where only a small number of isolated chambers were stained. The average living depth (ALD) (Jorissen et al., 1995) was calculated for the 10 taxa with at least five "live" specimens in one or more samples. We also calculated the median living depth (MLD) (Theodor et al., 2016) for these taxa. Differences between ALD and MLD are generally small but can be significant for taxa with a wide downcore occurrence range (Theodor et al., 2016). Foraminiferal abundances are reported as number per gram.

\subsection{Stable isotope analysis}

Oxygen and carbon isotope analyses were carried out on three species of foraminifera from BC737 (Astrononion echolsi, Cassidulinoides porrectus, and Buccella sp. 1), from 10 samples $(0-1$ to $9-10 \mathrm{~cm})$, and on two species from BC738 (Astrononion echolsi and Cassidulinoides porrectus) from 6 samples $(0-1$ to $5-6 \mathrm{~cm})$. All specimens for isotope analysis were picked from the $125-250 \mu \mathrm{m}$ fraction to minimize the possible effects of ontogenetic change in fractionation rates. These species were selected because their ALD/MLD revealed different microhabitat preferences and because they were present in high enough abundance to provide sufficient calcite to conduct the analyses. Each isotope data point was measured on between 4 and 15 specimens from each sample for A. echolsi and C. porrectus and on 3-5 specimens from each sample for the more heavily calcified Buccella sp. 1. The measurements were carried out at the NERC Isotope Geosciences Laboratory (NIGL), British Geological Survey (Keyworth, UK) using an IsoPrime 100 dualinlet mass spectrometer with Multiprep device. Isotope values were calculated according to the Vienna Pee Dee Belemnite (VPDB) scale in parts per thousand using a withinrun laboratory standard (KCM) calibrated to international NBS standards. Analytical reproducibility was $0.1 \%$ o $(1 \sigma)$ for both $\delta^{18} \mathrm{O}$ and $\delta^{13} \mathrm{C}$. To eliminate contamination by any organic carbon remaining in the test (the presence of the stain indicates that organic carbon is present within the tests), the samples were plasma ashed prior to analysis (at NIGL using an Emitech K1050X plasma asher). To test whether the plasma ashing process had any impact on the isotope composition of the foraminiferal calcite, five standards (KCM) were subjected to the same processing and analysed in parallel. In addition, to test whether the Rose Bengal stain had any impact on the isotope composition, five standards (KCM) mixed with Rose Bengal and five KCM standards mixed with Rose Bengal and plasma ashed were also analysed.

\section{Results}

\subsection{Benthic foraminiferal assemblage results}

A total of 1181 "live" (Rose Bengal stained) and 6505 dead specimens were identified from the sub-core sample sequences, representing 62 (36 "living" and 60 dead) taxonomic groupings (See "Systematic taxonomy" section and the Supplement). The total abundance for the upper $10 \mathrm{sam}$ ples from the sub-cores ranges from 6 to $16 \mathrm{~g}^{-1}$ for $\mathrm{BC} 737$, with the highest abundance evident in the $2-3 \mathrm{~cm}$ sample, and from 6 to $13 \mathrm{~g}^{-1}$ for $\mathrm{BC} 738$, with the highest abundance evident in the $0-1 \mathrm{~cm}$ sample. In $0-1 \mathrm{~cm}$ samples of the subcores, the ratio of "live" to dead specimens is 0.42 for $\mathrm{BC} 737$ and 0.32 for BC738 (Fig. 2). In BC737 this ratio decreases to 0.14 in the $3-4 \mathrm{~cm}$ sample before increasing to 0.37 in the $6-$ $7 \mathrm{~cm}$ sample, mainly due to the high abundance of "live" $M$. 

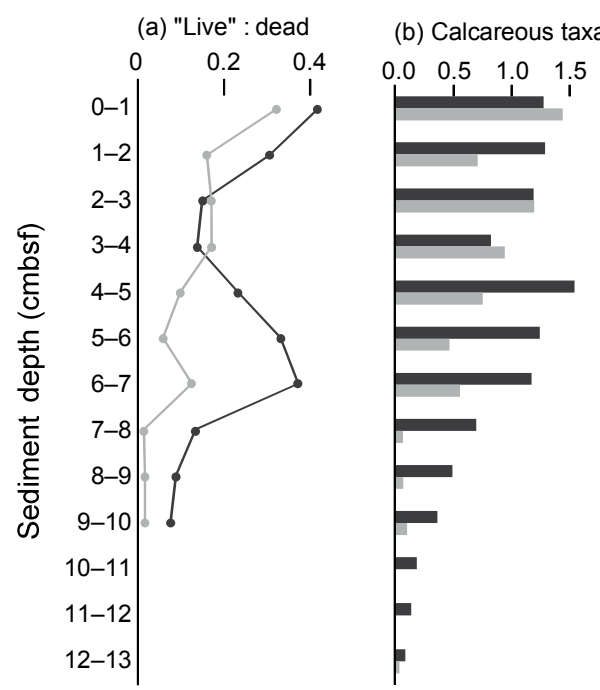

(c) C. porrectus

(d) A. echolsi

(e) F. fusiformis

(f) Buccella sp. 1
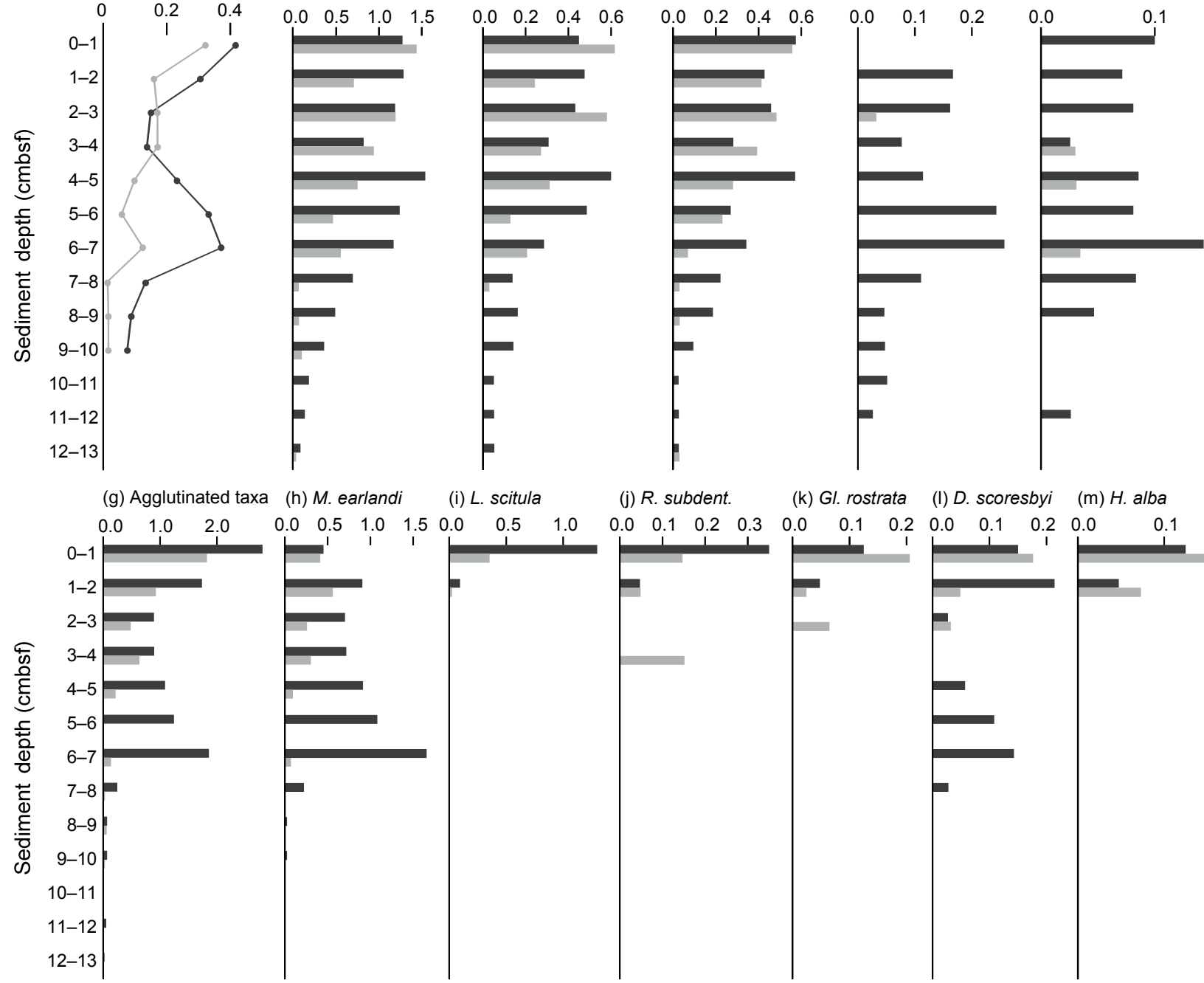

(j) R. subdent.

(k) Gl. rostrata

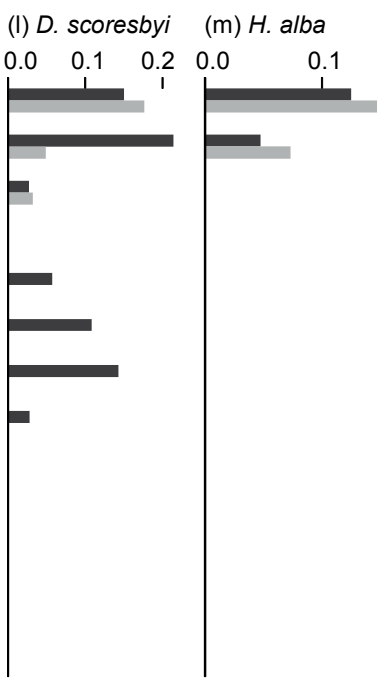

Figure 2. Downcore "live" : dead ratio and histograms showing downcore abundance of "live" (stained) foraminifera. BC7373 (dark grey) and BC738 (light grey) downcore "live" abundances (numbers per gram): (a) downcore "live": dead ratio; (b) total calcareous taxa; (cf) calcareous taxa with five or more "live" specimens in at least one sample; (g) total agglutinated taxa; (h-m) agglutinated taxa with five or more "live" specimens in at least one sample.

earlandi, and then decreasing to 0.08 in the $9-10 \mathrm{~cm}$ sample. In BC738 the "live" / dead ratio decreases steadily throughout the core to 0.02 in the $0-10 \mathrm{~cm}$ sample, apart from a small increase to 0.13 in the $6-7 \mathrm{~cm}$ sample. A small number of "live" taxa are still present in the $12-13 \mathrm{~cm}$ sample of both cores (4 specimens in BC737 and one in BC738).

The downcore variation in abundance of the 10 taxa with at least five "live" specimens in one or more samples are shown in Fig. 2 (for comparison the dead abundances of the same taxa are shown in Fig. 3). For six of these 10 taxa (A. echolsi, C. porrectus, F. fusiformis, Buccella sp. 1, M. earlandi, and D. scoresbyi), live specimens were recovered from a wide range of sediment depths, to at least $8 \mathrm{~cm}$, in at least one of the cores. The remaining four taxa ( L. scitula, Reophax subdentaliniformis, G. rostrata, and Hip- pocrepinella alba) were found to be restricted to the upper 0 to $2 \mathrm{~cm}$. The vertical range in living depths for individual species is presented in Fig. 4 where the error bars (1 SD) reveal a broad depth range of occurrences around the ALD for all species that do not present a restricted epifaunal/shallow infaunal microhabitat preference. There is a clear separation between the calcareous taxa, which were all found living at a range of sediment depths, and the agglutinated taxa, for which the majority were found living in the upper $2 \mathrm{~cm}$. The exceptions to this are $M$. earlandi and $D$. scoresbyi, which were recorded "living" at a range of depths in BC737, as was $R$. subdentaliniformis in $\mathrm{BC} 738$. The agreement between ALD and MLD is generally good, with a mean difference of $0.21 \mathrm{~cm}$. However, in BC737 the difference between ALD and MLD for $D$. scoresbyi is $1.33 \mathrm{~cm}$, with this difference 

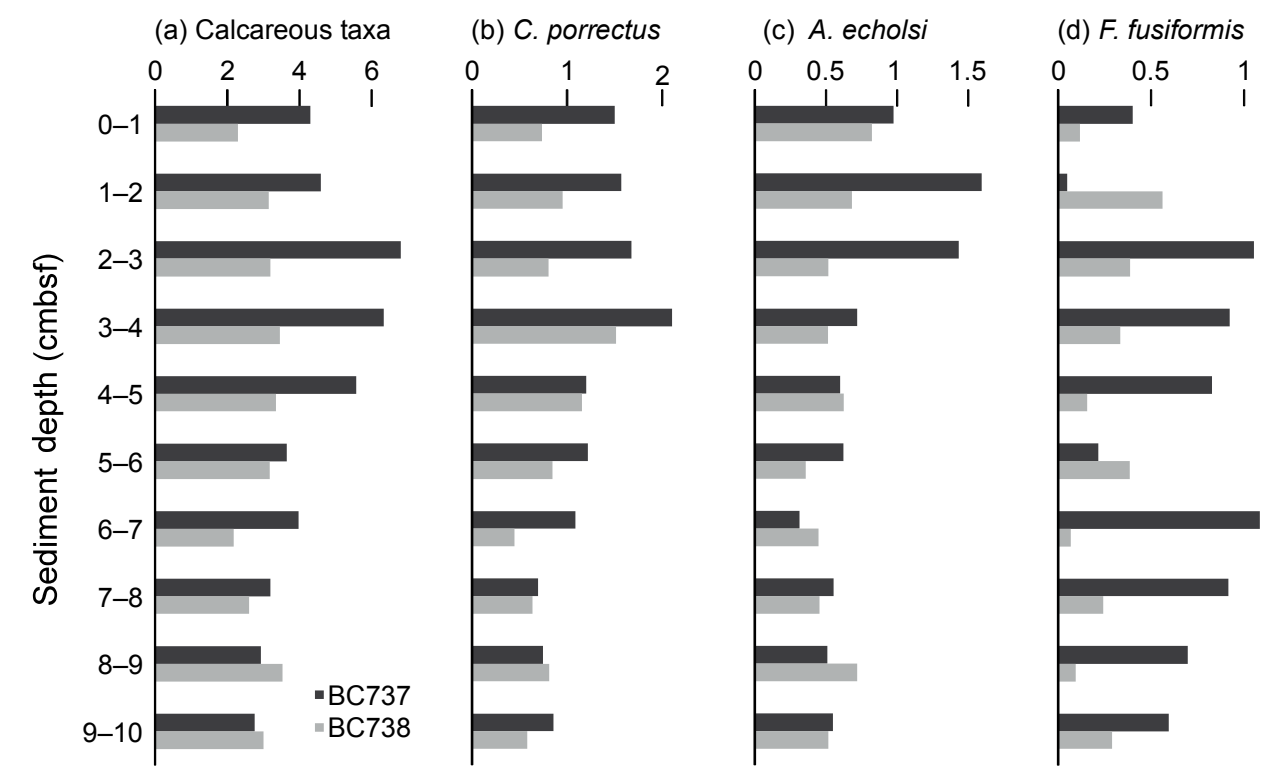

(e) Buccella sp. 1
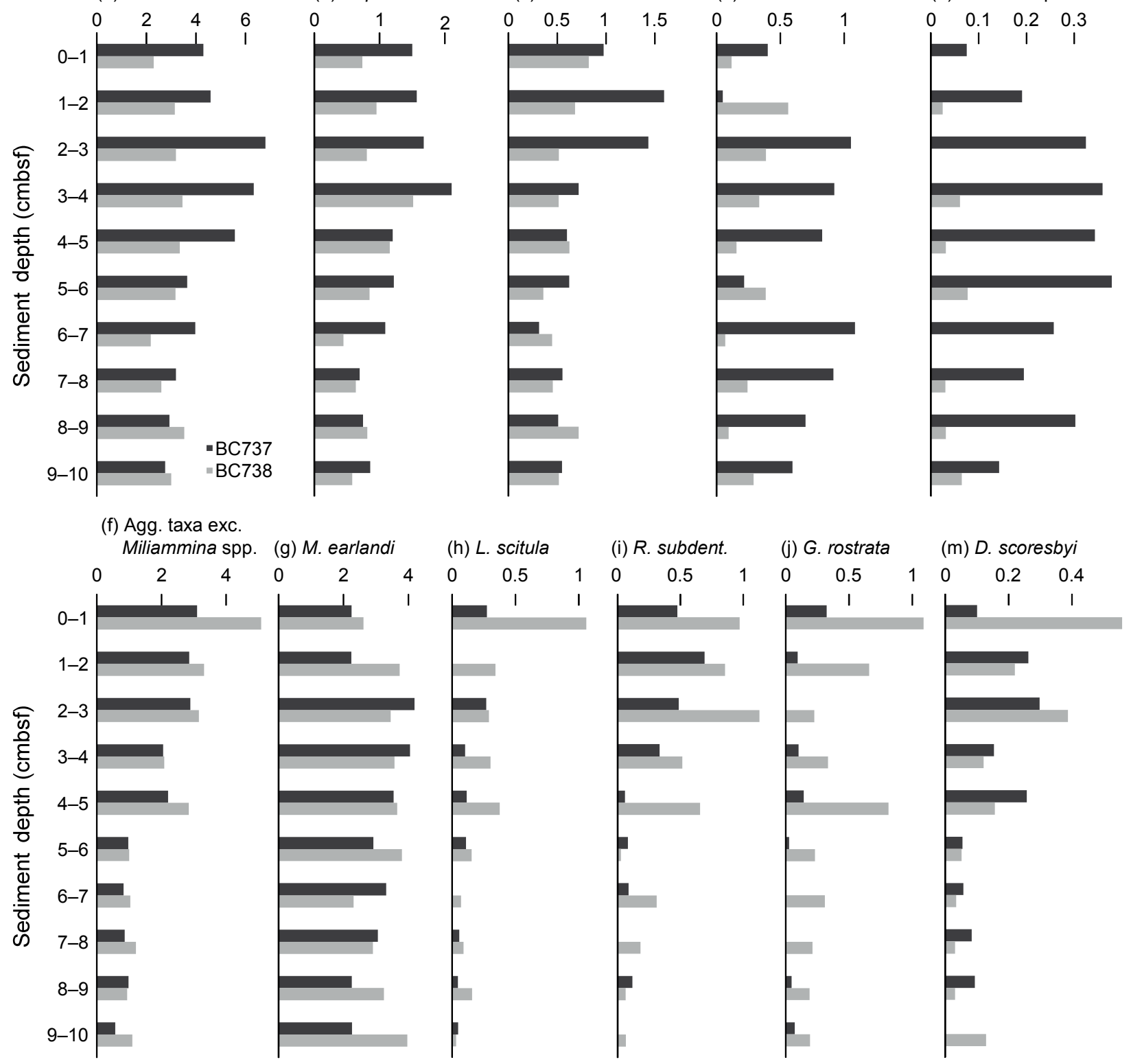

Figure 3. Histograms showing downcore abundance of dead foraminifera. BC7373 (dark grey) and BC738 (light grey) downcore "live" abundances no. $\mathrm{g}^{-1}$ ): (a) total calcareous taxa; (b-e) calcareous taxa with five or more "live" specimens in at least one sample; (f) total agglutinated taxa excluding Miliammina spp.; (g-m) agglutinated taxa with five or more "live" specimens in at least one sample (H. alba has not been plotted in this figure as no dead specimens of this taxon were recorded).

due to the bimodal depth distribution of "live" occurrences of this species. Whilst MLD and ALD are generally close within the same box core, there is a systematic difference between the living depths calculated for BC7373 and those calculated for BC738. For four of the five taxa where the difference is $>0.5 \mathrm{~cm}$, both ALD and MLD are shallower in $\mathrm{BC} 738$, relative to $\mathrm{BC} 737$, with the exception being $R$. subdentaliniformis, which is shallower in BC737.

The dead abundance of calcareous taxa in BC738 is stable throughout the core, whilst this abundance peaks between 2 and $4 \mathrm{~cm}$ in BC737 before becoming stable below this depth. This is in marked contrast to the dead abundance of agglutinated taxa (excluding Miliammina spp.), which shows a steady decline with depth in both cores such that, whilst agglutinated taxa are equal to or exceed calcareous taxa in dead assemblages in the upper core, calcareous taxa come to dominate dead assemblages as sediment depth increases. This trend appears linked to the preservation of taxa with epifaunal/shallow infaunal microhabitat preference as $L$. scitula, 


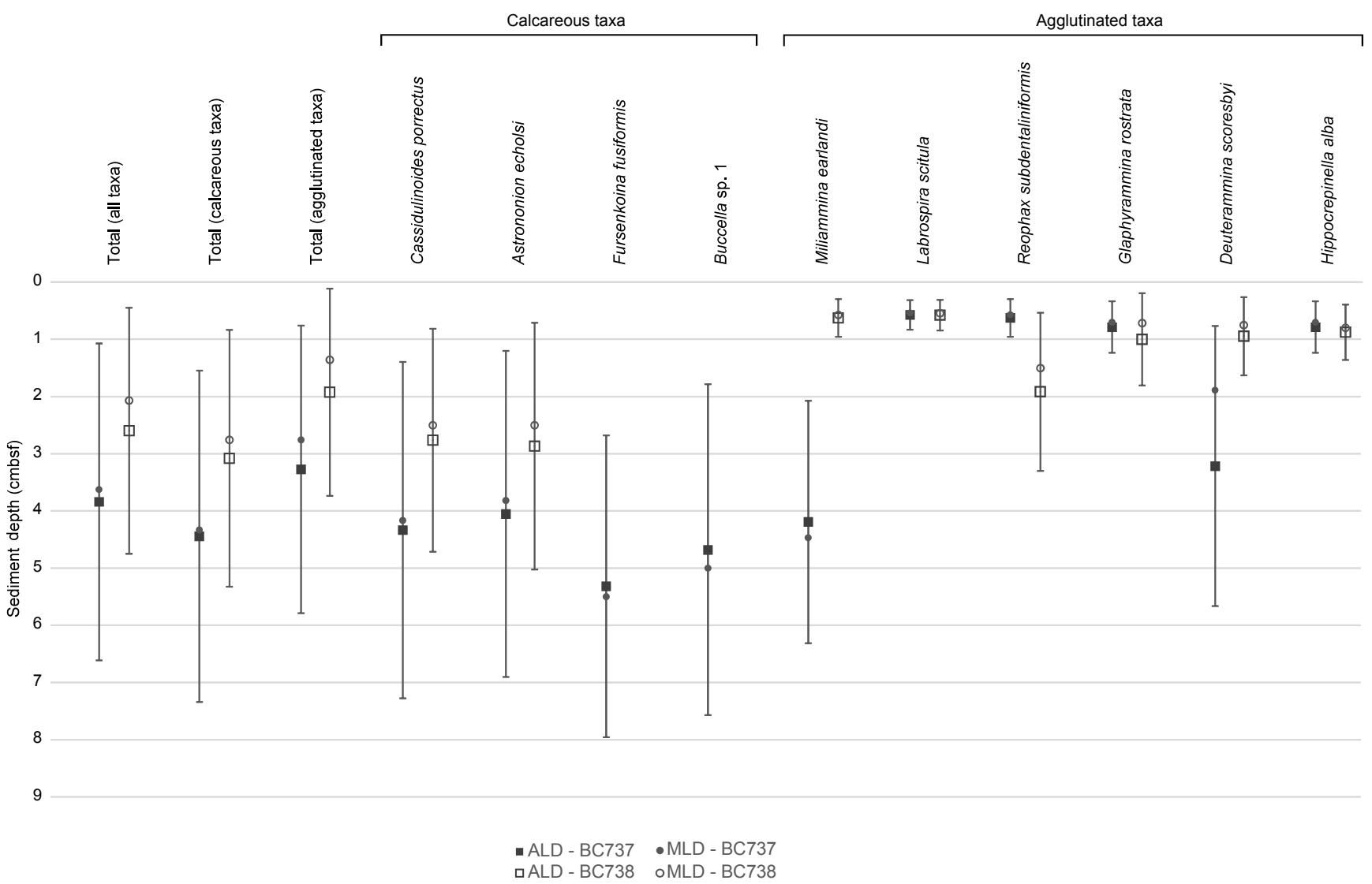

Figure 4. Average and median living depths.ALD (square symbols), calculated following Jorissen et al. (1995), and MLD (circular symbols), calculated following Theodor et al. (2016), plotted for all taxa, all calcareous taxa, all agglutinated taxa, and individually for the 10 taxa with five or more "live" specimens in at least one sample. Error bars represent the standard deviation about the ALD (1 SD). Closed symbols represent BC737 and open symbols represent BC738. Note that ALD and MLD have not been calculated for F. fusiformis and Buccella sp. 1 for BC738 as the "live" abundance of these taxa in this core was too low.

R. subdentaliniformis, and G. rostrata all exhibit a steep decline with depth in the number of dead specimens.

\subsection{Stable isotopes}

Results from the test isotope samples (KCM plus Rose Bengal, KCM plasma ashed, plasma ashed KCM plus Rose Bengal), run to establish whether these processing methods could have any impact on the foraminiferal isotope results, revealed that the values from the treated standards for both $\delta^{13} \mathrm{C}$ and $\delta^{18} \mathrm{O}$ were within the normal "within-run" error (Table 2).

The stable isotope compositions of "live" specimens display a relatively wide range of values, from -1.20 to $+0.72 \%$ o for $\delta^{13} \mathrm{C}$ and from +2.55 to $+3.56 \%$ for $\delta^{18} \mathrm{O}(\mathrm{Ta}-$ ble 3). Mean $\delta^{13} \mathrm{C}$ values for Astrononion echolsi, Cassidulinoides porrectus, and Buccella sp. 1 are $-0.84 \pm 0.15 \%$, $-0.34 \pm 0.15 \%$ o, and $+0.54 \pm 0.16 \%$ o respectively; mean $\delta^{18} \mathrm{O}$ values are $+2.85 \pm 0.20 \%$ o, $+3.40 \pm 0.09 \%$, and $+3.49 \pm 0.06 \%$. When plotted on a $\delta^{13} \mathrm{C} / \delta^{18} \mathrm{O}$ cross-plot (Fig. 5), samples from the same species cluster together, irrespective of the living depth. When $\delta^{13} \mathrm{C}$ is plotted against depth, it is clear that there is no systematic variation with depth (Fig. 6a). Similarly, no trends with depth are observed in $\delta^{18} \mathrm{O}$.

\section{Discussion}

\subsection{Benthic foraminiferal distributions}

In this study we identified 24 of the 345 species identified by Earland (1933), including 13 of the 24 species identified as being most typical of South Georgia assemblages, and 7 of the 14 species Earland described as being particularly characteristic of the region. The taxa identified as being most abundant by Earland (1933) include many of the more abundant species identified here, such as $M$. earlandi. The majority of species recorded in this study are present at a range of locations around the Southern Ocean, but there are five species that may be endemic to South Georgia (e.g. Labrospira sp. 1, G. rostrata, Recurvoides sp. 1, Buccella sp. 1, and Buccella sp. 2). In a comprehensive review of a range a data sources, encompassing a wide diversity of taxa, Hogg et al. (2011) 


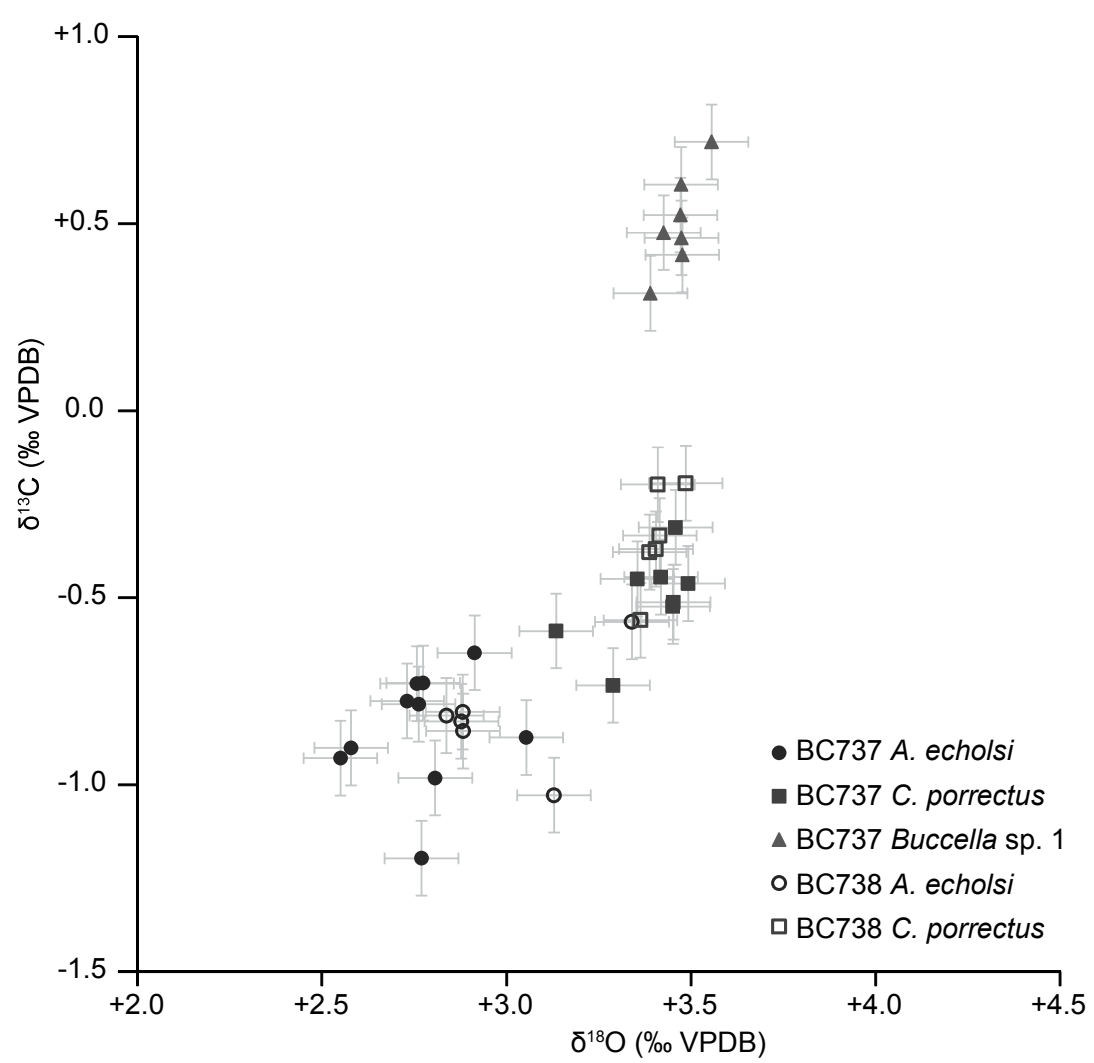

Figure 5. $\delta^{13} \mathrm{C}$ vs. $\delta^{18} \mathrm{O}$ cross-plot. Cross-plot of carbon and oxygen isotopic ratios for all samples analysed in this study. Astrononion echolsi - circular symbols; Cassidulinoides porrectus - square symbols; Buccella sp. 1 - triangular symbols (closed symbols - BC737; open symbols - BC738).

Table 2. Isotopic data from Rose Bengal test (STD: laboratory standard)

\begin{tabular}{|c|c|c|c|c|c|c|c|c|}
\hline & \multicolumn{2}{|l|}{$\begin{array}{l}\text { STD }+10 \% \\
\text { Rose Bengal }\end{array}$} & \multicolumn{3}{|c|}{$\begin{array}{c}\text { STD }+10 \% \\
\text { Rose Bengal plasma ashed }\end{array}$} & \multicolumn{3}{|c|}{ STD plasma ashed } \\
\hline & $\delta^{13} \mathrm{C}$ VPDB & $\delta^{18} \mathrm{O}$ VPDB & & $\delta^{13} \mathrm{C}$ VPDB & $\delta^{18} \mathrm{O}$ VPDB & & $\delta^{13} \mathrm{C}$ VPDB & $\delta^{18} \mathrm{O}$ VPDB \\
\hline RBKCM 1 & 1.99 & -1.77 & RBKCMP 1 & 1.92 & -1.67 & PKCM 1 & 1.92 & -1.76 \\
\hline RBKCM 2 & 1.91 & -1.81 & RBKCMP 2 & 1.88 & -1.89 & PKCM 2 & 2.05 & -1.57 \\
\hline RBKCM 3 & 1.98 & -1.76 & RBKCMP 3 & 1.91 & -1.58 & PKCM 3 & 2.02 & -1.63 \\
\hline RBKCM 4 & 1.96 & -1.81 & RBKCMP 4 & 1.93 & -1.72 & PKCM 4 & 2.02 & -1.65 \\
\hline RBKCM 5 & 1.91 & -1.89 & RBKCMP 5 & 1.91 & -1.62 & PKCM 5 & 1.94 & -1.74 \\
\hline Mean & 1.95 & -1.81 & Mean & 1.91 & -1.69 & Mean & 1.99 & -1.67 \\
\hline $1 \mathrm{SD}$ & 0.04 & 0.05 & $1 \mathrm{SD}$ & 0.02 & 0.12 & $1 \mathrm{SD}$ & 0.06 & 0.08 \\
\hline
\end{tabular}

highlighted the significance of endemism within the South Georgia shelf ecosystem and its importance to global biodiversity, and the identification of potentially unidentified species of foraminifera further adds to that diversity. The benthic foraminiferal assemblage documented here suggests that, whilst there may be partial isolation, the microfauna of South Georgia are connected to those of the rest of the Southern Ocean. A total of 20 species identified in this study were also recorded by Ishman and Domack (1994) in their study of the Bellingshausen Sea margin; 22 of the 105 species identified by Majewski (2005), from King George Island, are also recorded in this study, as are 11 of the 26 species identified by Majewski and Anderson (2009) from the Firth of Tay. The strong affinity with Antarctic Peninsula taxa suggests that the position of South Georgia in the path of the ACC downstream of the Antarctic Peninsula (AP) allows for a degree of microfaunal connectivity between the two. The species that are commonly recorded from both the AP and South Georgia in- 
(a)

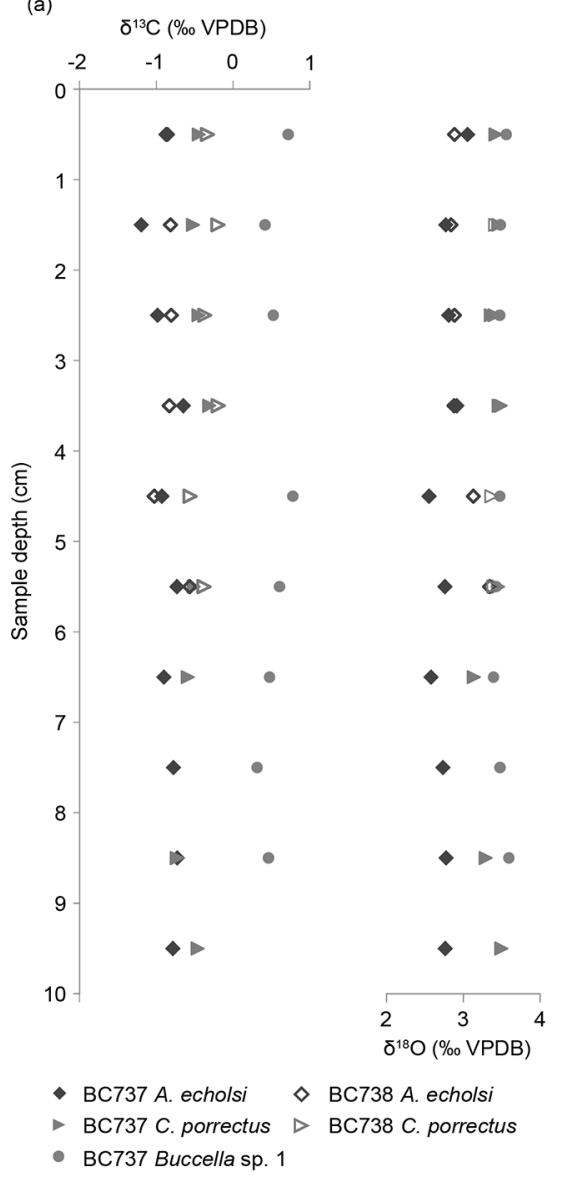

(b)

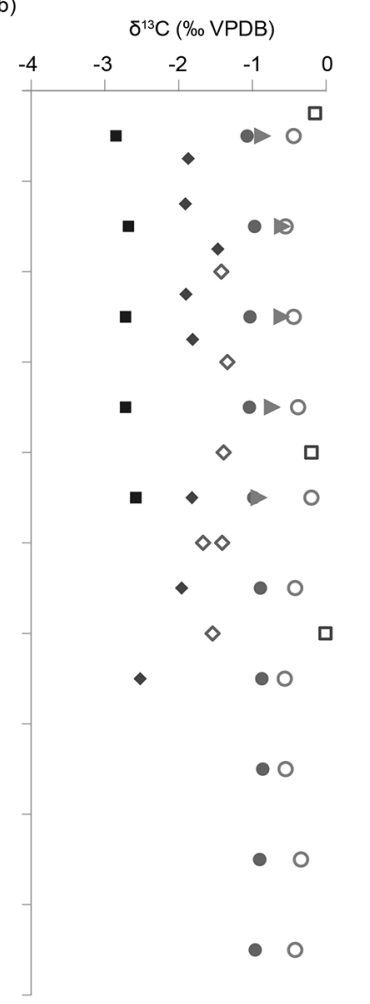

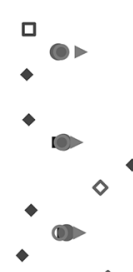

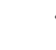

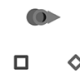

$\square \diamond$

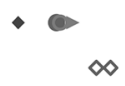

$\infty$

$\rightarrow$

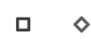

$\bullet 0$

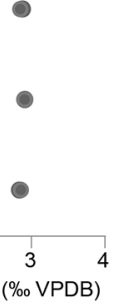

- Globobulimina affinis (CH90-BC6)

- Pleurostomella alternans (CH90-BC1)

- Bolivina spissa ( $\mathrm{CH} 90-\mathrm{BC} 1)$

Uvigerina peregrina ( $\mathrm{CH} 90-\mathrm{BC} 5)$ (c)

$\delta^{13} \mathrm{C}$ (normalized)

$\begin{array}{lllllllll}-2 & -1.5 & -1 & -0.5 & 0 & 0.5 & 1 & 1.5 & 2\end{array}$

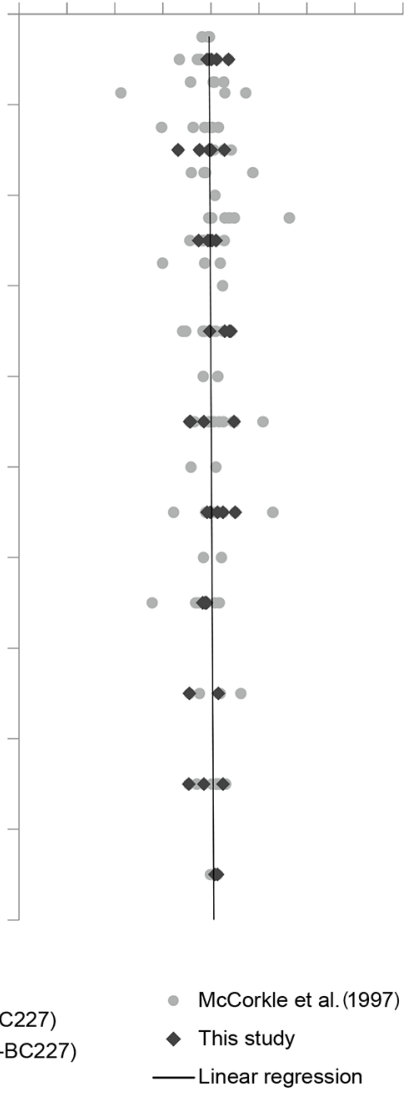

Figure 6. Isotopic data plotted against sample depth. (a) Carbon and oxygen isotopic values for species analysed in this study. (b) Carbon and oxygen isotopic values for seven species analysed in McCorkle et al. (1997). (c) Carbon and oxygen isotopic values for species analysed in this study and in McCorkle et al. (1997), normalized by subtracting the mean value for each species from the individual value. There is no systematic variation in either $\delta^{13} \mathrm{C}_{\text {foram }}$ or $\delta^{18} \mathrm{O}_{\text {foram }}$ with sample depth in any of these three plots.

clude Portatrochammina antarctica weisneri, Reophax subdentaliniformis, A. echolsi, Spiroplectammina biformis, Nonionella bradii, N. iridea, C. parkerianus, C. porrectus, and F. fusiformis, many of which are among the more abundant taxa. A comparable level of similarity is seen with studies of Weddell Sea benthic foraminifera (Mackensen et al., 1990; Anderson, 1975).

There is less similarity between the South Georgia foraminiferal fauna and those recorded from more remote areas of the Southern Ocean. For example, only six of the taxa recorded here were also recorded by Herb (1971) from the Drake Passage. However, this may be due to the openocean/deep-water nature of these locations, rather than proximity, as there are greater levels of connectivity between our sites and more distal locations on the Antarctic shelf, including Pine Island Bay and Terra Nova Bay (Majewski, 2013; Violanti, 1996).

The decreasing abundance of "live" specimens with depth within the sediment (Fig. 2) reflects well-established gradi- ents in organic carbon and oxygen availability (see Jorissen et al., 2007). The shallower ALD/MLD observed in BC738 across almost all taxa (Fig. 4) may indicate steeper oxygen and organic carbon concentration gradients at this location. Variation in these gradients between the two sites may be linked to differences in sedimentation rate or carbon flux, with the latter potentially linked to BC738's closer proximity to seasonal phytoplankton blooms occurring north-west of South Georgia. The interruption in the decreasing "live" abundance trend seen in the agglutinated taxa in BC737 is the result of a peak in "live" abundance of a single species, M. earlandi, between 5 and $7 \mathrm{~cm}$.

Dead abundances in both cores peak around the ALD/MLD for all taxa combined; the decline in dead abundances below this depth can be attributed to the physical and chemical breakdown of the tests. The decrease in dead abundance is more pronounced in the agglutinated taxa, indicating that the organic matrix of agglutinated tests has a greater susceptibility to taphonomic processes. An exception 
Table 3. Isotopic data from "live" (stained) foraminifera.

\begin{tabular}{lrrr|rr|rr}
\hline & & \multicolumn{2}{c}{ A. echolsi } & \multicolumn{2}{c|}{ C. porrectus } & Buccella sp. 1 \\
\cline { 3 - 7 } Core & Depth & $\delta^{13}$ C VPDB & $\delta^{18}$ O VPDB & $\delta^{13}$ C VPDB & $\delta^{18}$ O VPDB & $\delta^{13}$ C VPDB & $\delta^{18}$ O VPDB \\
\hline BC737 & $0-1 \mathrm{~cm}$ & -0.87 & 3.06 & -0.45 & 3.42 & 0.72 & 3.56 \\
BC737 & $1-2 \mathrm{~cm}$ & -1.20 & 2.77 & -0.52 & 3.45 & 0.42 & 3.48 \\
BC737 & $2-3 \mathrm{~cm}$ & -0.98 & 2.81 & -0.45 & 3.36 & 0.52 & 3.47 \\
BC737 & $3-4 \mathrm{~cm}$ & -0.65 & 2.92 & -0.31 & 3.46 & - & - \\
BC737 & $4-5 \mathrm{~cm}$ & -0.93 & 2.55 & - & - & 0.78 & 3.48 \\
BC737 & $5-6 \mathrm{~cm}$ & -0.73 & 2.76 & -0.51 & 3.46 & 0.60 & 3.43 \\
BC737 & $6-7 \mathrm{~cm}$ & -0.90 & 2.58 & -0.59 & 3.14 & 0.48 & 3.39 \\
BC737 & $7-8 \mathrm{~cm}$ & -0.78 & 2.73 & - & - & 0.31 & 3.48 \\
BC737 & $8-9 \mathrm{~cm}$ & -0.73 & 2.78 & -0.73 & 3.29 & 0.46 & 3.59 \\
BC737 & $9-10 \mathrm{~cm}$ & -0.79 & 2.76 & -0.46 & 3.50 & - & - \\
\hline & Mean & -0.86 & 2.77 & -0.50 & 3.38 & 0.54 & 3.49 \\
& $1 \mathrm{SD}$ & 0.16 & 0.15 & 0.12 & 0.12 & 0.16 & 0.06 \\
\hline BC738 & $0-1 \mathrm{~cm}$ & -0.86 & 2.88 & -0.33 & 3.42 & NA & NA \\
BC738 & $1-2 \mathrm{~cm}$ & -0.82 & 2.84 & -0.20 & 3.41 & NA & NA \\
BC738 & $2-3 \mathrm{~cm}$ & -0.81 & 2.88 & -0.37 & 3.41 & NA & NA \\
BC738 & $3-4 \mathrm{~cm}$ & -0.83 & 2.88 & -0.19 & 3.49 & NA & NA \\
BC738 & $4-5 \mathrm{~cm}$ & -1.03 & 3.13 & -0.56 & 3.37 & NA & NA \\
BC738 & $5-6 \mathrm{~cm}$ & -0.56 & 3.34 & -0.38 & 3.39 & NA & NA \\
\hline & Mean & -0.82 & 2.99 & -0.34 & 3.41 & NA & NA \\
& $1 \mathrm{SD}$ & 0.15 & 0.20 & 0.14 & 0.04 & NA & NA \\
\hline
\end{tabular}

to this is $M$. earlandi, whose dead abundance remains stable in both sub-cores, likely due to its siliceous cement being more resistant to chemical breakdown (Earland, 1933). This enhanced downcore loss of agglutinated taxa, relative to calcareous taxa, illustrates the well-recognized complication of fossil/dead assemblages not truly reflecting living assemblages due to the loss of taxa with poor preservation potential (e.g. Majewski, 2005; Jorissen et al., 2007; Stefanoudis et al., 2017).

\subsection{Sediment living and calcification depths}

Many of the most abundant infaunal taxa recorded in BC737 and $\mathrm{BC} 738$ do not appear to have a clear preference for a specific living depth. However, it is important to recognize the potential limitations of the Rose Bengal staining technique in identifying truly living specimens. Where decay rates are slow, Rose Bengal may stain foraminifera that have been dead for months to several years (Corliss and Emerson, 1990). It is therefore important to apply criteria that are as strict as possible when categorizing which specimens are living and which are dead (e.g. Fontanier et al., 2016; Caulle et al., 2015) and to bear this limitation in mind when considering live abundances arrived at through Rose Bengal staining. It is also possible for specimens identified as living at a certain depth interval to have been transported there after death by bioturbation (see Bernhard, 2000, and references therein). If bioturbation were controlling the distribu- tion of specimens within our data, we would expect to see all taxa affected such that it would not be possible to identify any depth-restricted habitat preferences. The restricted distribution of $L$. scitula, $R$. subdentaliniformis, and G. rostrata to epifaunal/very shallow infaunal environments contradicts bioturbation being prevalent at our sites. Furthermore, where decay rates are very slow, specimens that appear live at different depths within the sediment column may be significantly older than the overlying live assemblages. This is dependent on the sedimentation rate being high enough to bury specimens to a significant depth before decay is sufficiently progressed that staining with Rose Bengal will no longer occur, and such age control in not available for the samples studied here. Whilst it is important to recognize the limitations of Rose Bengal staining, it is simple, reliable, and inexpensive to use and is currently the most appropriate technique to apply when, as in this study, the samples are processed immediately upon collection (Bernhard, 2000). In addition, Murray and Bowser (2000) have proposed that, in oxygenated environments, dead tests are unlikely to retain protoplasm due to predation being the most likely cause of death. Whilst we did not directly measure the oxygenation of the sediments studied here, there was no indication of anoxia or dysoxia from the colour and odour of the sediments on recovery.

As discussed in the Introduction, it is commonly assumed that foraminifera calcify at their living depth and record the pore water $\delta^{13} C_{\text {DIC }}$ in their test isotopic composition 


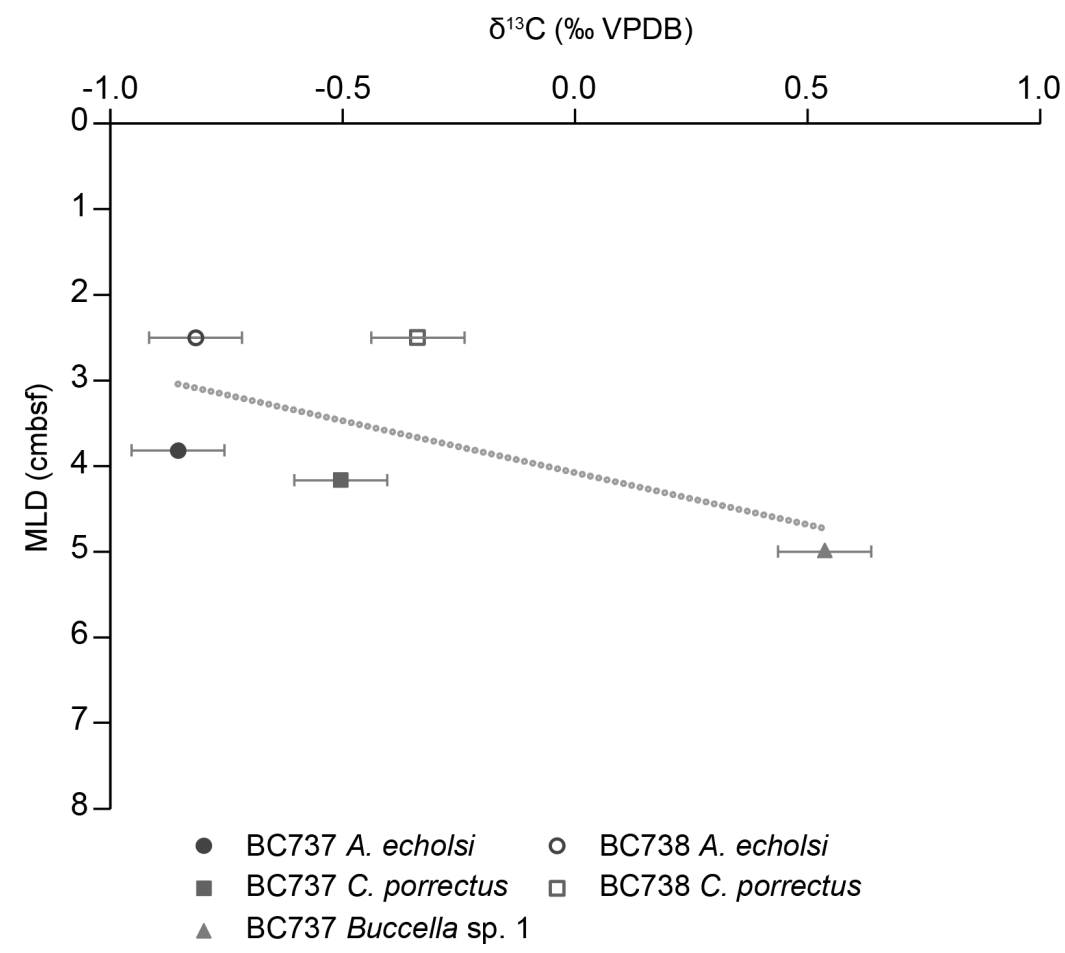

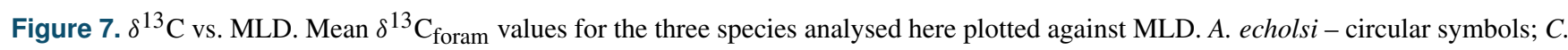
porrectus - square symbols; Buccella sp. 1 - triangular symbols (closed symbols - BC737; open symbols - BC738). Error bars: 1 SD.

or an isotopic composition offset from that of pore water by species-specific vital effects. Whilst downcore pore water $\delta^{13} \mathrm{C}_{\text {DIC }}$ data are not available for the cores studied here, records from various other locations consistently report that pore water $\delta^{13} \mathrm{C}_{\mathrm{DIC}}$ decreases (becomes more negative) with increased sediment depth (e.g. McCorkle et al., 1997; Holsten et al., 2004; Loubere et al., 2011; Luo et al., 2013), before stabilizing below the oxygen penetration depth. Furthermore, Gehlen et al. (1999) have modelled how the interaction of oxic organic matter decay and $\mathrm{CaCO}_{3}$ dissolution generate this gradient within marine sediments. We therefore assume that a negative gradient of some kind will be present in sediments from the South Georgia shelf. The observed increase in $\delta^{13} C_{\text {foram }}$ with increased MLD (Fig. 7) is the opposite of the expected trend were each species calcifying at their respective MLDs. However, there are multiple vital-effect factors that lead to different inter-species $\delta^{13} \mathrm{C}$ offsets despite specimens calcifying from waters with the same $\delta^{13} \mathrm{C}_{\text {DIC }}$ (see review in Ravelo and Hillaire-Marcel, 2007), and without prior knowledge of the impact of these vital effects for each species, we cannot use this as evidence that these species do not calcify at their MLD.

Assessing the intra-species isotope data from the three species analysed here, we note that the depth- $\delta^{13} \mathrm{C}_{\text {foram }}$ relationship we would anticipate, were the foraminifera calcifying with the pore water $\delta^{13} \mathrm{C}_{\mathrm{DIC}}$ at the depth from which they were recovered, does not hold true; i.e. intra-species $\delta^{13} \mathrm{C}$ does not decrease with depth (Fig. 6a). The range of inter-species $\delta^{13} \mathrm{C}$ and $\delta^{18} \mathrm{O}$ compositions considerably exceeds the intra-species range (Fig. 5). Other studies that have reported isotope data from live foraminifera at a range of living depths have also noted limited variability in the intraspecies stable isotope composition. For example, Bolivina spissa, Bulimina aculeata, Cibicidoides wuellerstorfi, Uvigerina peregrina, Pleurostomella alternans, Globobulimina affinis, and G. pacifica (McCorkle et al., 1997) from midlatitude continental margins in the Atlantic and Pacific oceans show no systematic downcore isotope variations (Fig. 6b), even though the isotopic composition of the same species can vary significantly between locations (e.g. G. affinis) (for further examples, see McCorkle et al., 1990; Tachikawa and Elderfield, 2002; Schmiedl et al., 2003; Fontanier et al., 2006b, 2008). When we normalize our $\delta^{13} C_{\text {foram }}$ data, and the data of McCorkle et al. (1997), by subtracting the mean for each species at each sample location, there is no trend away from that mean with depth (Fig. 6c) even though all pore water $\delta^{13} \mathrm{C}_{\text {DIC }}$ values in those locations (where measured) exhibit a gradient.

If the individual foraminifera were calcifying at the depth at which they were found living (as inferred by Fontanier et al., 2006b, and Theodor et al., 2016, amongst others), we would expect our intra-species $\delta^{13} \mathrm{C}$ data, and those of other studies (e.g. McCorkle et al., 1997), to reflect a decreasing $\delta^{13} \mathrm{C}_{\text {DIC }}$ gradient with depth, which they do not. The con- 
sistency of intra-species isotope data (Fig. 6), despite their broad range of living depths (Figs. 2 and 6), are good evidence that benthic foraminifera calcify at a fixed depth location, and possibly within a specific season, because they fail to capture the variability of pore water $\delta^{13} \mathrm{C}_{\text {DIC }}$ that their observed living depth would expose them to.

\subsection{Foraminiferal calcification strategies}

Many have concluded that the observed inter-species differences in $\delta^{13} \mathrm{C}$ are due to species preferences for different depth microhabitats, and their position on the $\delta^{13} \mathrm{C}_{\text {DIC }}$ gradient, implying that calcification occurs infaunally at a specific, restricted depth for each species (e.g. McCorkle et al., 1990; Schmiedl et al., 2004; Theodor et al., 2016). To account for fixed intra-species $\delta^{13} \mathrm{C}$ compositions of infaunal taxa requires calcification to only occur at certain times during the organism's life when it is exposed to a fixed $\delta^{13} \mathrm{C}_{\text {DIC }}$ value. We discuss two previously proposed calcification strategies of infaunal species - at a specific depth within the sediment and within macro-/meio-faunal burrows - and propose a third, novel strategy: calcification at the sediment-seawater interface.

In the first strategy, calcification only occurs at a specific depth within the sediment and this depth relates to the preferred microhabitat of the species: broadly speaking epifaunal, shallow infaunal, or deep infaunal. There is evidence for this strategy in some species: for example Holsten et al. (2004) found that the $\delta^{13} \mathrm{C}_{\text {foram }}$ in three species (Bolivina argentea, B. subadvena, and Buliminella tenuata) matched the pore water $\delta^{13} \mathrm{C}_{\mathrm{DIC}}$ at their maximum live abundance depth. However, if the species studied here calcified at a preferred depth within the sediment, we need to question what is controlling/determining the narrow calcification depth range (in contrast to the observed wide living depth range) and why it is apparently not the ALD/MLD. We note that, on the South Georgia shelf, species with deeper ALD/MLD have heavier $\delta^{13} \mathrm{C}$ compositions (Fig. 7), whilst pore waters are assumed to change (e.g. become isotopically lighter) with depth.

The second strategy involves calcification in association with the burrows of larger fauna, where voids within the sediment allow pore water isotopic composition to be homogenous across a range of depths (Loubere et al., 1995; Schmiedl et al., 2004), meaning that calcification within a burrow would result in the same $\delta^{13} \mathrm{C}_{\text {foram }}$ composition regardless of depth. Loubere et al. (2011) have proposed that all calcareous foraminifera use this strategy, with the activities of macro-/meio-fauna allowing foraminifera to choose micro-habitats with particular geochemical conditions within the complex "bio-irrigation" systems the larger fauna create.

Our third hypothesis, that calcification occurs at the sediment-seawater interface, is supported, in principal, by the presence of live specimens of many of the infaunal calcareous taxa recorded in this study (and e.g. McCorkle et al., 1997 ) within the top $2 \mathrm{~cm}$ of the sediment. Foraminifera are known to be capable of migrating throughout the sediment column (e.g. Linke and Lutze, 1993; Geslin et al., 2004) and the occurrence of infaunal species at these shallow depths within the sediment demonstrates their ability to migrate to the sediment-seawater interface. Weldeab et al. (2016) have recorded the presence of a steep $\left[\mathrm{CO}_{3}^{2-}\right]$ gradient between bottom water and pore water and also within the sediment column. This $\left[\mathrm{CO}_{3}^{2-}\right]$ gradient suggests that the sedimentseawater interface may provide the most energy-efficient location for calcification, due to the greater availability of carbonate ions. In addition, food (phytodetrital matter from the overlying water column) availability and/or type is greatest at the sediment-seawater interface. Whilst from the stable isotope data on living specimens published here and elsewhere, it is not possible to prove that the species were calcifying at the sediment-seawater interface, we conclude that this may be the simplest explanation for the stability of inter-species isotopic composition.

Alternatively, there may be no requirement to calcify at a specific depth, or within specific geochemical conditions, and foraminifera may be capable of calcifying at a range of sediment depths and a corresponding range of pore water $\delta^{13} \mathrm{C}_{\text {DIC }}$ compositions. Calcification across a range of sediment depths could result in foraminiferal calcite recording an average of the range in pore water $\delta^{13} \mathrm{C}_{\mathrm{DIC}}$ compositions, with any inter-species variation accounted for by speciesspecific vital effects. The presence of "living" specimens of the species studied here at a range of sediment depths and the absence of a clear maximum "live" abundance depth are not inconsistent with this calcification strategy.

\subsection{Implications of sediment-seawater interface calcification for palaeoenvironmental research}

Were foraminiferal calcification only to occur at the sediment-seawater interface, why do inter-species $\delta^{13} \mathrm{C}$ offsets vary on annual, decadal, centennial, and longer timescales? As discussed above (see Introduction), $\delta^{13} \mathrm{C}$ offsets between epifaunal and infaunal taxa, assumed to be indicative of the pore water $\delta^{13} \mathrm{C}_{\text {DIC }}$ gradient, have been used to reconstruct past changes in organic matter flux and sea floor oxygenation (e.g. McCorkle and Emerson, 1988; Zahn et al., 1986; Schilman et al., 2003; Hoogakker et al., 2015). Considering our hypothesis that infaunal species migrate to the sediment-seawater interface to calcify, we propose that changes in epifaunal-infaunal offsets are controlled by the timing of calcification; epifaunal and shallow infaunal taxa calcify persistently, even during periods of relatively low $\mathrm{C}_{\text {org }}$ availability (oligotrophic/mesotrophic conditions), and infaunal taxa calcify only during periods of high $\mathrm{C}_{\text {org }}$ availability (eutrophic conditions). Deeper infaunal taxa may be opportunistic, potentially "hibernating" or at least not calcifying new chambers, at depth during oligotrophic periods when food is scarce and migrating to the sediment-seawater interface to feed and calcify during eutrophic periods. 
Supporting this hypothesis, Ohga and Kitazato (1997) observed that, at their study site in Sagami Bay, Japan, all foraminifera where found living in the uppermost part of the sediment column during the peak of phytodetrital flux. Kitazato et al. (2000) have proposed that deep-infaunal taxa may migrate to the sediment-seawater interface to take advantage of phytodetrital input and to reproduce. Furthermore, in laboratory experiments Nomaki et al. (2005) recorded that many infaunal foraminifera, especially the taxa they classified as shallow or intermediate infauna, migrated upwards through the sediment column in response to an addition of food at the surface. This migration may be quite rapid, with foraminifera capable of moving through several millimetres of sediment in a day (e.g. Gross, 2000), although Witte et al. (2003) found that foraminifera took 8 days to respond to a phytodetritus pulse. In a simulated phytodetritus event Sweetman et al. (2009) found that the uptake of added carbon, labelled with ${ }^{13} \mathrm{C}$, was confined to surface-living specimens of the deep-infaunal Globobulimina turgida. However, we note that Enge et al. (2011) did not record a significant response by deeper infaunal taxa to a simulated phytodetritus pulse, although this may be due to the short duration (4 days) of their experiment. It is also important to note that it has been hypothesized that deep-infaunal taxa may have a preference for degraded organic matter (Caralp, 1989; Fontanier et al., 2003), which if correct may further delay their response to influxes of labile organic matter from phytodetrital pulses. Whilst these studies are consistent with our hypothesis that infaunal taxa migrate to the sediment-seawater interface during eutrophic conditions and calcify, no studies have yet recorded when calcification occurs.

In our scenario, infaunal $\delta^{13} \mathrm{C}$ records are therefore biased towards eutrophic conditions (even if this is just a brief seasonal pulse of $\mathrm{C}_{\text {org }}$ to the sea floor), while epifaunal/shallow infaunal $\delta^{13} \mathrm{C}$ records are more reflective of mean annual conditions at the sea floor. Since deep-infaunal $\delta^{13} \mathrm{C}$ is biased towards periods of enhanced $\mathrm{C}_{\text {org }}$ flux to the sea floor, downcore records from the $\delta^{13} \mathrm{C}$ of these taxa are potentially less sensitive to variability in $\mathrm{C}_{\text {org }}$ flux. The abundance of opportunistic infaunal species, however, can increase dramatically by accelerating growth and/or reproduction during eutrophic episodes (e.g. Gooday, 1988; Gooday and Hughes, 2002; Fontanier et al., 2006a; Peck et al., 2015) due to greater organic carbon availability and their tolerance of lower oxygen concentrations (Piña-Ochoa et al., 2010). Downcore epifaunal $\delta^{13} \mathrm{C}$ is potentially a more sensitive indicator of variable $\mathrm{C}_{\text {org }}$ flux and bottom water conditions (oxygenation). During periods of exceptionally high productivity, epifaunal $\delta^{13} \mathrm{C}$ may converge with infaunal $\delta^{13} \mathrm{C}$ records, reflecting a prolonged abundance of $\mathrm{C}_{\text {org }}$ at the seafloor throughout the year.

\section{Summary}

In this study, we show that the diversity of benthic foraminifera does not vary greatly at our study sites across the South Georgia shelf and that there are similarities between the assemblages recorded here and those found on the Antarctic Peninsula and elsewhere on the Antarctica shelf, particularly among the more abundant taxa. We find that for most of the taxa in this study, there is no strong preference for a specific living depth, except for a small number of species that exhibit a preference for an epifaunal/shallow infaunal microhabitat (e.g. Labrospira scitula and Glaphyrammina rostrata).

We find little intra-species variation in $\delta^{13} \mathrm{C}$ of the tests of the "living" benthic foraminiferal species analysed here (Astrononion echolsi, Cassidulinoides porrectus, Buccella sp. 1), despite their recovery from a range of depths (and assumed pore water isotopic compositions) below the sea floor. The failure of $\delta^{13} \mathrm{C}_{\text {foram }}$ from depth-restricted samples to document the pore water $\delta^{13} \mathrm{C}_{\mathrm{DIC}}$ gradient common to marine sediments suggests that infaunal taxa calcify at a fixed $\delta^{13} \mathrm{C}_{\text {DIC }}$ and therefore depth (e.g. McCorkle et al., 1990; Schmiedl et al., 2004; Theodor et al., 2016). Whilst we are not able to conclusively state that the species studied here calcify at the sediment-seawater interface, this hypothesis is consistent with (i) the presence of "live" individuals of all the most abundant taxa in the upper $1-2 \mathrm{~cm}$ of sediment in this study (and other studies), (ii) the documented ability of foraminifera to migrate through the sediment column (e.g. Linke and Lutze, 1993; Geslin et al., 2004), (iii) the absence of a strong living depth preference in this study (and other studies), and (iv) the sediment-seawater interface being the most energetically favourable location for calcification (greatest $\mathrm{C}_{\text {org }}$ and $\left[\mathrm{CO}_{3}^{2-}\right]$ availability).

We propose that epifaunal taxa live and calcify at the sediment-seawater interface throughout a wide range of organic carbon availability scenarios (oligotrophic to eutrophic). Infaunal species, however, may only calcify when the concentration of organic carbon at the seafloor is high and they migrate to the sediment-seawater interface to feed. In this scenario, temporal (downcore) variability in the offsets between epifaunal and infaunal $\delta^{13} \mathrm{C}$ would reflect changing fluxes of organic carbon to the seafloor, causing variation in $\delta^{13} \mathrm{C}_{\text {DIC }}$ between oligotrophic and eutrophic conditions. Our hypothesis, therefore, has important implications for the use of benthic foraminiferal $\delta^{13} \mathrm{C}$ offsets as proxies of productivity and oxygenation and for the use of trace metal ratios $(\mathrm{Mg} / \mathrm{Ca}, \mathrm{B} / \mathrm{Ca})$ in reconstructing pore water temperature and $\Delta\left[\mathrm{CO}_{3}^{2-}\right]$. However, we maintain that changes in epifaunal-infaunal foraminiferal $\delta^{13} \mathrm{C}$ offsets through time are likely to reflect the evolution of phytoplankton blooms and water mass chemistry (cf. Hoogakker et al., 2015). This study further highlights the need for a good understanding of foraminiferal ecology when utilizing isotopic composition in interpreting palaeoenvironmental change. Further work is 
needed to investigate the timing and depth of calcification in calcareous benthic foraminifera and the test-forming depths for agglutinated benthic foraminifera.

\section{Systematic taxonomy}

The following species and taxonomic groupings are arranged in taxonomic order following the supra-generic classifications of Kaminski (2004) for the agglutinated taxa and Loeblich and Tappan (1988) for the calcareous walled taxa. Species identification is largely based on the works of Heron-Allen and Earland (1932a), Earland (1933), Anderson (1975), Mackensen et al. (1990), Ishman and Domack (1994), Violanti (1996), Igarashi et al. (2001), and Majewski (2005, 2013). Eleven additional species have been described, recorded in benthic foraminiferal assemblage work on sediment from surface samples from other box cores and gravity cores collected from the South Georgia shelf (Table 1 and Fig. 1) that were not present in the sub-cores. Described species are illustrated in Figs. 8-14.

Family Rhabdamminidae Brady, 1884

Subfamily Rhabdammininae Brady, 1884

Genus Rhabdammina M. Sars in Carpenter, 1869.

\section{Rhabdammina spp.}

(Fig. 8:1)

Material. Thirteen specimens from six samples.

Description. Included in this group are any thick-walled tube fragments comprising coarsely agglutinated material with rough external surface and very smooth internal cavity.

Family Hippocrepinellidae Loeblich \& Tappan, 1984 emend. Mikhalevich, 1995

Genus Hippocrepinella Heron-Allen \& Earland, 1932b

Hippocrepinella alba Heron-Allen \& Earland, 1932b

(Fig. 8:2)

1932b Hippocrepinella alba Heron-Allen \& Earland: 259, pl. 1, figs. 16-18.

1933 Hippocrepinella alba Heron-Allen \& Earland; Earland: 71, pl. 7, figs. 10-12.

Material. Twenty-eight specimens from seven samples.

Description. Unilocular, cylindrical to fusiform test; smooth, thin, white wall constructed of very small particles; aperture round at end of narrow neck, which may have a collar; may also have a secondary basal aperture.
Occurrence. Originally described from the South Atlantic (Heron-Allen and Earland, 1932b) and subsequently recorded from South Georgia (Earland, 1933), both from surface samples.

Family Rhizamminidae Wiesner, 1931

Genus Rhizammina Brady, 1879

Rhizammina spp.

(Fig. 8:3-5)

Material. Forty-nine specimens from nine samples.

Description. Included in this group are any elongate tubular tests with thin, flexible walls; only broken tubes recovered in this study; specimens recorded here mainly composed of diatomaceous material.

Family Saccamminidae Brady, 1884

Subfamily Saccammininae Brady, 1884

Genus Lagenammina Rhumbler, 1911

Lagenammina cf. sphaerica Moreman, 1930

(Fig. 8:6)

1930 Lagenammina sphaerica Moreman: 51, pl. 5, fig. 15.

Material. Seventy specimens from 13 samples.

Description. Unilocular, near spherical test; thin agglutinated wall; medium sand grains; rough surface; simple aperture produced at the end of an elongate neck; neck approximately two fifths of test length.

Remarks. As Lagenammina sphaerica Moreman was described from Silurian deposits in the USA, this cannot be the same species. However the morphological similarities are uncanny. The species described here does bear some similarity to the extant Lagenammina arenulata (Skinner) that is common at other Antarctic localities, but this species does not possess an elongate neck. Jones (1994) suggests that specimens similar to $L$. arenulata (Skinner), but with an elongate neck, belong to L. atlantica (Cushman). However, the original description of this species reveals that it too does not possess an elongate neck.

Genus Saccammina Carpenter, 1869

\section{Saccammina spp.}

(Fig. 8:8)

Material. Four specimens from three samples. 


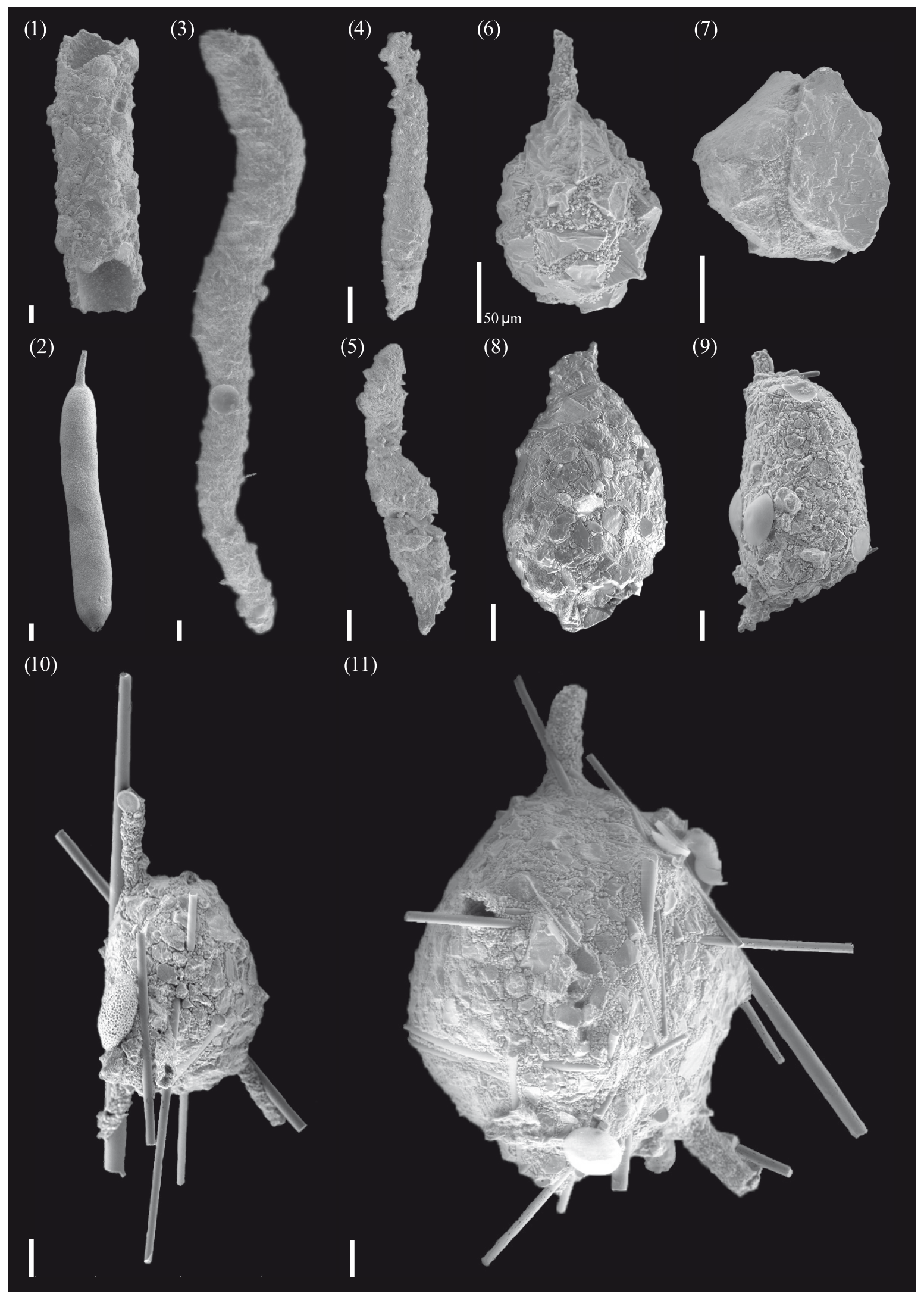

Figure 8. (1) Rhabdammina spp. (BC738). (2) Hippocrepinella alba Heron-Allen and Earland (BC738). (3-5) Rhizammina spp. (BC738). (6) Lagenammina cf. sphaerica (Moreman) (BC737). (7) Psammosphaera bowmanni Heron-Allen and Earland (BC738). (8) Saccammina spp. (BC737 (D) 7-8 cm; BC738 (D) 0-1 cm). (9-11) Astrammina rara Rhumbler (BC737). (Scale bar $100 \mu \mathrm{m}$ unless otherwise indicated.) 
Description. Included in this group are any forms that have a globular, unilocular test, with a firm, fine to medium agglutinated wall held together with an organic cement, and a round aperture produced on a short neck.

Subfamily Thurammininae Miklukho-Maklay, 1963

Genus Astrammina Rhumbler in Wiesner, 1931

Astrammina rara Rhumbler in Wiesner, 1931

(Fig. 8:9-11)

1931 Astrammina rara Rhumbler, in Wiesner: 78, pl. 2, fig. 19.

1932b Armorella sphaerica Heron-Allen \& Earland: 257, pl. 2, figs. 4-11.

1932b Pelosphaera cornuta Heron-Allen \& Earland: 255, pl. 2, figs. 12-15.

1933 Armorella sphaerica Heron-Allen \& Earland; Earland: 65, pl. 7, figs. 16-23.

1933 Pelosphaera cornuta Heron-Allen \& Earland; Earland, 61, pl. 7, figs. 24-27.

Material. Twelve specimens from six samples.

Description. Large, near-spherical, unilocular test with a number of narrow "arms" extending in various directions, often along sponge spicules that are incorporated into the test wall. Wall firmly agglutinated, comprising fine to coarse sand grains, sponge spicules, and diatoms, with a grey to yellowish brown cement.

Occurrence. Originally described from the South Atlantic (Heron-Allen and Earland, 1932b) and subsequently recorded from South Georgia (Earland, 1933), both from surface samples.

Remarks. The synonymy of Astrammina rara Rhumbler, Armorella sphaerica Heron-Allen \& Earland, and Pelosphaera cornuta Heron-Allen \& Earland was demonstrated by DeLaca (1986) in an analysis of live Antarctic specimens.

Family Psammosphaeridae Haeckel, 1894

Subfamily Psammosphaerinae Haeckel, 1894

Genus Psammosphaera Schulze, 1875

Psammosphaera bowmanni Heron-Allen \& Earland, 1912

(Fig. 8:7)

1912 Psammosphaera bowmanni Heron-Allen \& Earland: pl. 5, figs. 5-6, pl. 6, fig. 5 .
2010 Capsammina bowmanni (Heron-Allen \& Earland); Gooday et al.: 349, pl. 1, figs. A \& B.

Material. Four specimens from three samples.

Description. Free, monothalamous test, comprising several small flat grains of mica cemented by very fine cement that form an irregular polyhedral chamber. Openings are visible where the flakes meet and cement is absent, which may be the aperture or accidental.

Occurrence. Originally described from North Sea dredgings (Heron-Allen and Earland, 1912), it was subsequently recorded in the north-east Atlantic (Gooday et al., 2010).

Remarks. Heron-Allen and Earland (1912) were unable to assign a definite oral aperture, recording openings similar to those recorded here on some specimens but not all. Heron-Allen and Earland (1912) also note that this species is difficult to describe, as no two specimens look exactly alike. The flakes are arranged to approximately make an oval or flask shape, and the gaps, the size of which may vary considerably, between the flakes are then filled with cement, so that the cemented areas vary from narrow infill to broad flat areas.

Psammosphaera fusca Schulze, 1875

(Fig. 9:1-2)

1875 Psammosphaera fusca Schulze: 113, pl. 2, fig. 8. 1994 Psammosphaera fusca Schulze; R. W. Jones: 31, pl. 18, figs. 1-8.

2003 Psammosphaera fusca Schulze; Gaździcki \& Majewski: 7, fig. 3 (1-2).

Material. Forty-six specimens from 15 samples.

Description. Small spherical test; usually unilocular, occasionally multiple chambers loosely joined. Agglutinated wall comprising medium to coarse grains in a fine cement.

Occurrence. Recorded from several locations in the Atlantic (Jones, 1994) and Antarctica (Gaździcki and Majewski, 2003), all from Recent sediments.

Family Ammodiscidae Reuss, 1862

Subfamily Ammodiscinae Reuss, 1862

Genus Ammodiscus Reuss, 1862

Ammodiscus incertus (d'Orbigny, 1839a)

(Fig. 9:5-6)

1839a Operculina incerta d'Orbigny: 49, pl. 6, figs. 16-17. 


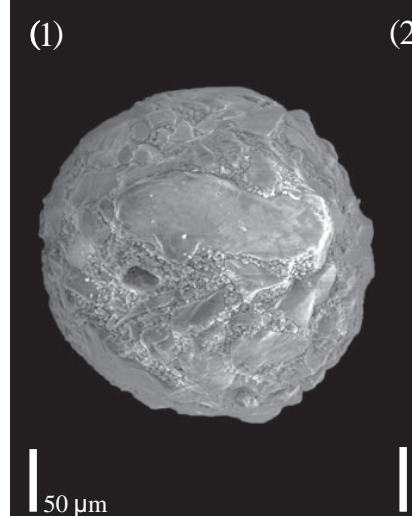

(5)

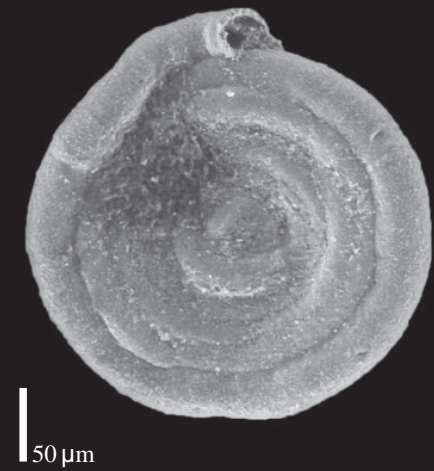

(2)

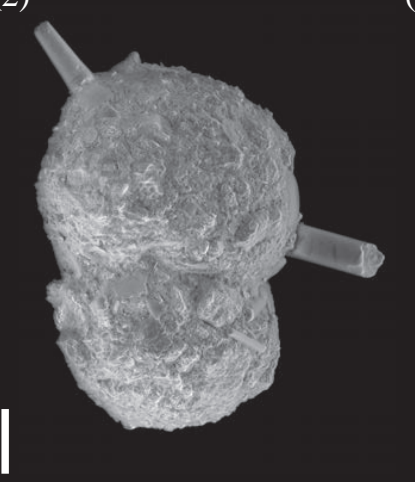

(6)

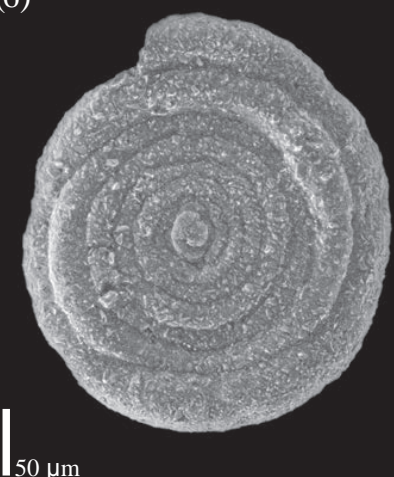

(3)

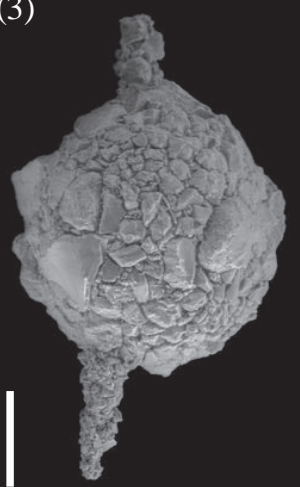

(7)
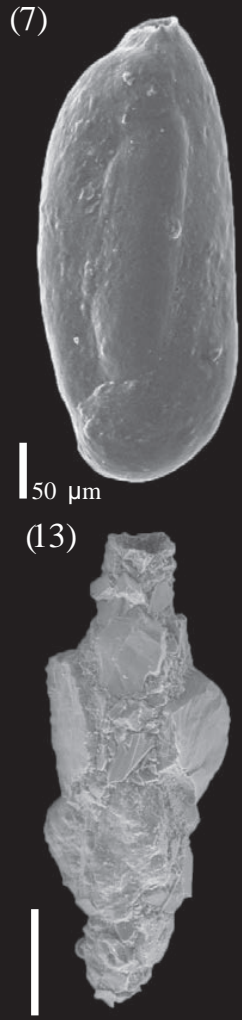

(18)
(4)
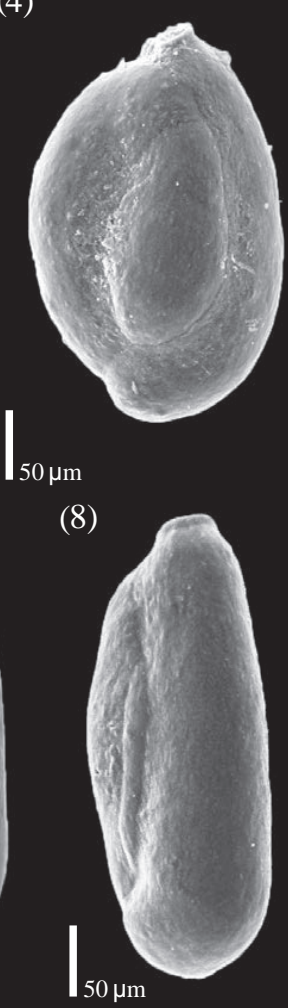

(14)
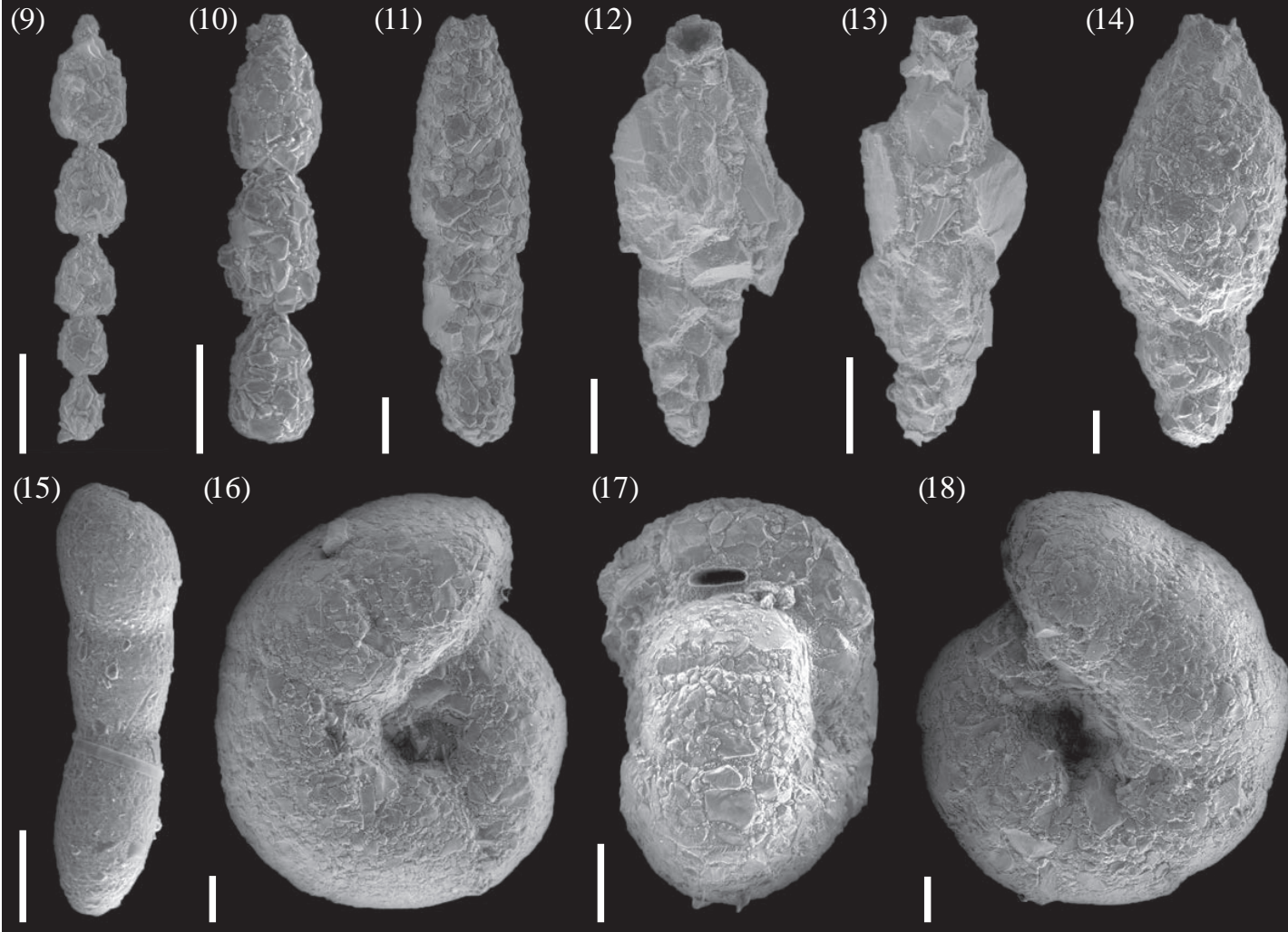

(17)

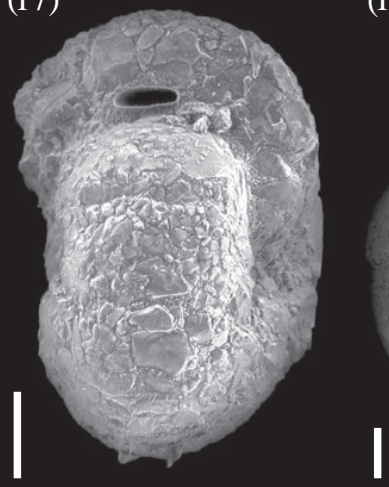

(18)

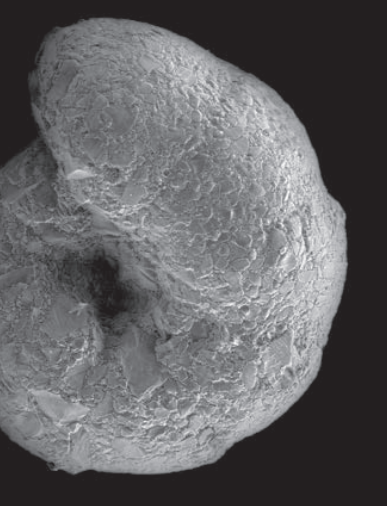

Figure 9. (1-2) Psammosphaera fusca Schulze (BC737 (D) 0-1 cm). (3) Hormosinella sp. (BD738). (4) Miliammina lata Heron-Allen and Earland (GC666_002). (5-6) Ammodiscus incertus (d'Orbigny) (BC737). (7-8) Miliammina earlandi Loeblich and Tappan (GC666_002). (9-10) Hormosinelloides guttifer (Brady) (BC667). (11) Nodulina dentaliniformis (Brady) (BC737 (D) 0-1 cm). (12-13) Reophax subdentaliniformis Parr (BC738). (14) Reophax subfusiformis Earland emend. Höglund (BC667). (15) Pseudonodosinella sp. (BC737 (D) 9-10 cm). (16-18) Labrospira scitula (Brady) (BC738). (Scale bar $100 \mu \mathrm{m}$ unless otherwise indicated.) 
1996 Ammodiscus incertus (d'Orbigny); Violanti: 53, pl. 3, fig. 6.

2001 Ammodiscus sp.; Igarashi et al.: 142, pl. 2, fig. 5.

2013 Ammodiscus incertus (d'Orbigny); Majewski: 175, fig. 3(4).

Material. Overall, 109 specimens from 22 samples.

Description. Small test (ca. $200 \mu \mathrm{m}$ diameter), generally flat but tending towards irregular coiling in the last whorls. Up to seven whorls in microspheric form and up to six in megalospheric form; sutures between whorls somewhat depressed; proloculus spherical and central. The agglutinated test wall comprises angular grains of sand in a cement matrix that is a yellow-brown colour. Aperture a simple opening at the end of the tubular chamber.

Occurrence. Recorded from a number of locations on the Antarctic shelf (Violanti, 1996; Igarashi et al., 2001; Majewski, 2013), from Recent sediments.

Family Rzehakinidae Cushman, 1933

Subfamily Miliammininae Saidova, 1981

Genus Miliammina Heron-Allen \& Earland, 1930

Miliammina earlandi Loeblich \& Tappan, 1955

(Fig. 9:7-8)

1933 Miliammina oblonga (Heron-Allen \& Earland); Earland: 92, pl. 3, fig. 17, pl. 5, figs. 1-5, 7-8.

1955 Miliammina earlandi Loeblich \& Tappan: 12, pl. 1, figs. 15-16.

1981 Miliammina earlandi Loeblich \& Tappan; Milam \& Anderson: 304, pl. 2, fig. 4.

1996 Miliammina earlandi Loeblich \& Tappan; Violanti: 53, pl. 3, figs. 10-11.

2004 Miliammina earlandi Loeblich \& Tappan; Murray \& Pudsey: 71, pl. 1, figs. 8-9.

Material. Overall, 3240 specimens from 34 samples.

Description. Tubular chambers with a rounded peripheral edge, arranged in a quinqueloculine pattern; sutures slightly depressed, increasing as test size increases. Wall comprises very small mineral grains (whose composition is unclear) completely embedded in siliceous cement (insoluble in $\mathrm{HCl}$ ), smooth/polished surface. Very light grey in colour, and large variation in test size. Crescentiform aperture is at the terminal end of the final chamber, flush or with a slight neck. There is considerable morphological variation within this species due to variation in the roundness of the chambers.
Occurrence. Originally described from the South Atlantic (Heron-Allen and Earland, 1930) and subsequently reported from several locations of the Antarctic shelf (Milam and Anderson, 1981; Violanti, 1996; Murray and Pudsey, 2004), from Recent sediments.

Remarks. Whilst initially included in Miliammina $o b$ longa (Chapman) by Heron-Allen and Earland (1930), this South Georgia form was later separated from Miliammina arenacea (Chapman) by Earland (1933) due to its more ovate and rounded outline and was renamed Miliammina oblonga Heron \& Earland. However, Loeblich and Tappan (1955) recognized that this species name had previously been assigned to Miliolina oblonga (Montagu), incorrectly placed in Miliammina, and renamed it Miliammina earlandi (which we use here). Earland (1933) considered M. earlandi to be the most characteristic and commonest foraminifera of the South Georgia area.

Miliammina lata Heron-Allen \& Earland, 1930

(Fig. 9:4)

1930 Miliammina lata Heron-Allen \& Earland: 43, pl. 1, figs. 13-17.

1933 Miliammina lata Heron-Allen \& Earland; Earland: 93, pl. 3, fig. 17, p. 5, figs. 15-19.

1996 Miliammina lata Heron-Allen \& Earland; Violanti: 52, pl. 3, fig. 12 .

2001 Miliammina lata Heron-Allen \& Earland; Igarashi et al.: 140, pl. 2, fig. 10 .

2005 Miliammina lata Heron-Allen \& Earland; Majewski: 193, fig. 12(8).

2013 Miliammina lata Heron-Allen \& Earland; Majewski: 176, fig. 4(3).

Material. Sixty specimens from 13 samples.

Description. Quinqueloculine test; early chambers often not visible; inflated, broadly rounded chambers, broadening at the base. Slightly depressed sutures; thick, smooth, agglutinated wall comprising very small particles in an excess of siliceous cement. Small crescentiform aperture at the end of the final chamber.

Occurrence. Originally described from the South Atlantic (Heron-Allen and Earland, 1930), it was subsequently recorded from South Georgia (Earland, 1933) and a number of locations on the Antarctic shelf (Igarashi et al., 2001; Violanti, 1996; Majewski, 2005, 2013), all from Recent sediments.

Family Hormosinellidae Rauzer-Chernousova \& Reytlinger, 1986 
Genus Hormosinella Shchedrina, 1969

\section{Hormosinella sp.}

(Fig. 9:3)

Material. Three fragmentary specimens from one sample.

Description. Large, uniserial test; ovate/fusiform chambers separated by long, delicate, necks. Thin, agglutinated wall; rounded terminal aperture on elongate neck.

Remarks. Only recorded here as fragmentary specimens.

Genus Hormosinelloides Zheng \& Fu, 2001

Hormosinelloides guttifer (Brady, 1881)

(Fig. 9:9-10)

1881 Lituola (Reophax) guttifera Brady: 49, pl. 31, figs 1015.

1975 Reophax guttifer (Brady); Anderson: 74, pl. 1, fig. 18. 1994 Hormosinella guttifera (Brady); R. W. Jones: 38, pl. 31, figs. 10-15.

2005 Hormosinelloides guttifer (Brady); Kaminski \& Gradstein: 249 , pl. 46, figs. 1-8.

Material. Thirty-one specimens from four samples.

Description. Uniserial test comprising a series of approximately three to five pyriform chambers. Thin, agglutinated wall with a fairly rough finish. Simple, rounded aperture; terminal on an elongated neck.

Occurrence. Originally described from the South Atlantic by Brady (1881) who recorded that it was "exceedingly rare", it was subsequently recorded from the Weddell Sea (Anderson, 1975), from Recent sediments.

Remarks. Placed in the genus Hormosinelloides by Kaminski and Gradstein (2005) because the chambers attach near the base of the apertural neck of the preceding chamber.

Family Reophacidae Cushman, 1927

Genus Nodulina Rhumbler, 1895

Nodulina dentaliniformis (Brady, 1881)

(Fig. 9:11)

1881 Lituola (Reophax) dentaliniformis Brady: 49, pl. 30, figs. 21-22.

1994 Reophax dentaliniformis (Brady); R. W. Jones: 37, pl. 30, figs. 21-22.

2017 Nodulina dentaliniformis (Brady); Kender \& Kaminski: pl. 8, fig. 1 .
Material. Six specimens from one sample.

Description. Slender, elongate test with straight axis; three to six chambers; final chamber significantly larger and tapered; wall comprises sand grains in firm cement, with a smooth finish. Large, round terminal aperture on a short tubular neck of finer grains.

Occurrence. Recorded from the South Pacific, the North Atlantic (Brady, 1881; Jones, 1994), and the Bering Sea (Kender and Kaminski, 2017).

Remarks. Nodulina dentaliformis (Brady) is the type species of the genus Nodulina, which is distinguished from Reophax by its more symmetrical, regular chambers, horizontal sutures, and straighter axis.

Genus Reophax de Montfort, 1808

Reophax subdentaliniformis Parr, 1950

(Fig. 9:12-13)

1950 Reophax subdentaliniformis Parr: 269, pl. 4, fig. 20. 1996 Nodulina subdentaliniformis (Parr); Violanti: 53, pl. 3, fig. 18.

2005 Nodulina subdentaliniformis (Parr); Majewski: 194, fig. 13(6-7).

Material. Overall, 457 specimens from 25 samples.

Description. Slender, elongate test with a slight curvature; usually four to six chambers (may be difficult to distinguish); final chamber significantly larger and tapered. Wall comprises poorly sorted sand grains in firm cement, coarsely finished. Large, round terminal aperture on a short neck of finer sand grains.

Occurrence. Recorded from Recent Antarctic sediments (Parr, 1950; Violanti, 1996; Majewski, 2005).

Remarks. We have placed this species within the genus Reophax on the basis of the curvature of the test.

Reophax subfusiformis Earland, 1933 emend. Höglund, 1947

(Fig. 9:14)

1933 Reophax subfusiformis Earland: 74, pl. 2, figs. 16-19. 1947 Reophax subfusiformis Earland; Höglund: 77.

2004 Reophax subfusiformis Earland; Murray \& Pudsey: 72, pl. 2, fig. 5.

2005 Reophax subfusiformis Earland; Kaminiski \& Gradstein: 275, pl. 54, figs. 1-8. 

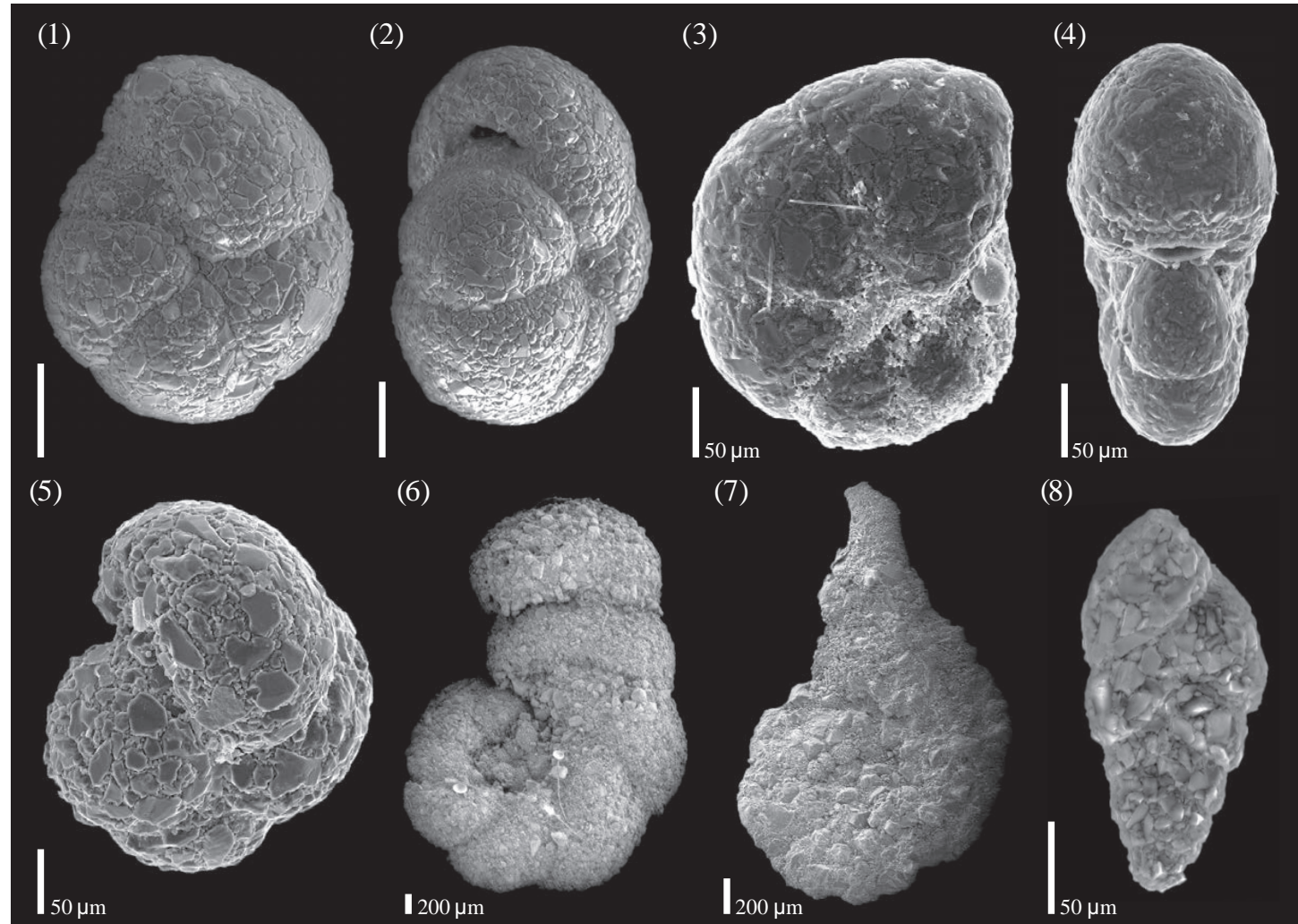

(9)

(10)

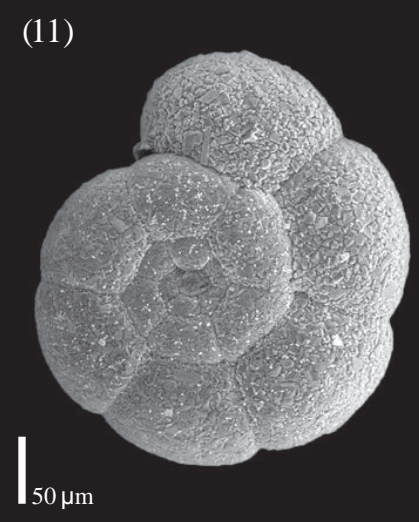

(12)
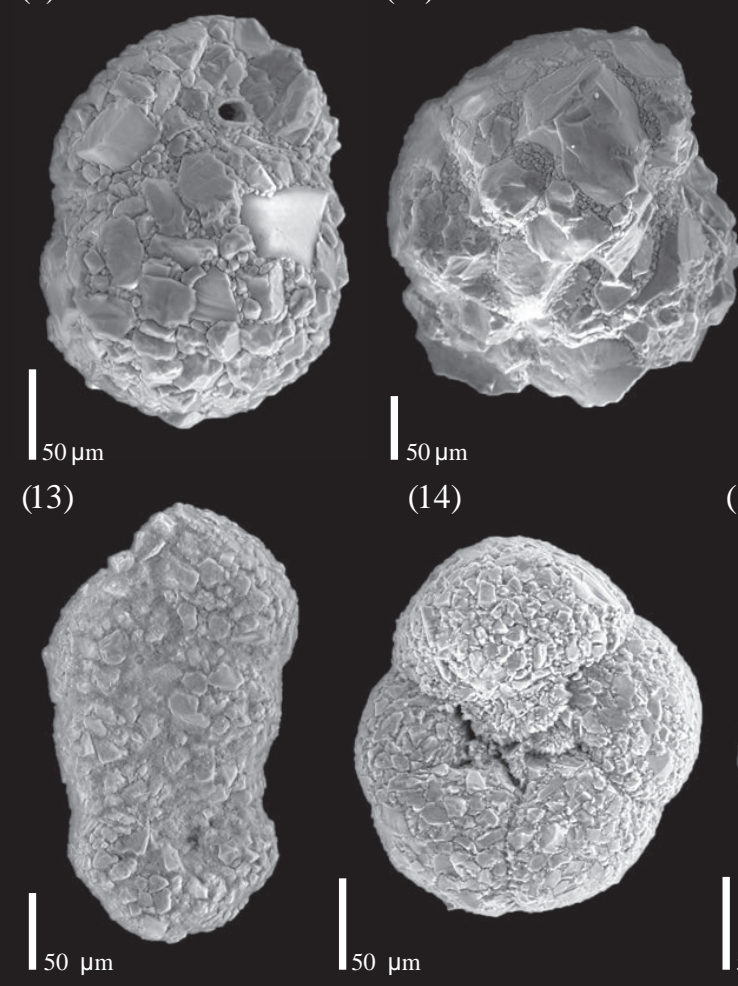

(14)

(15)
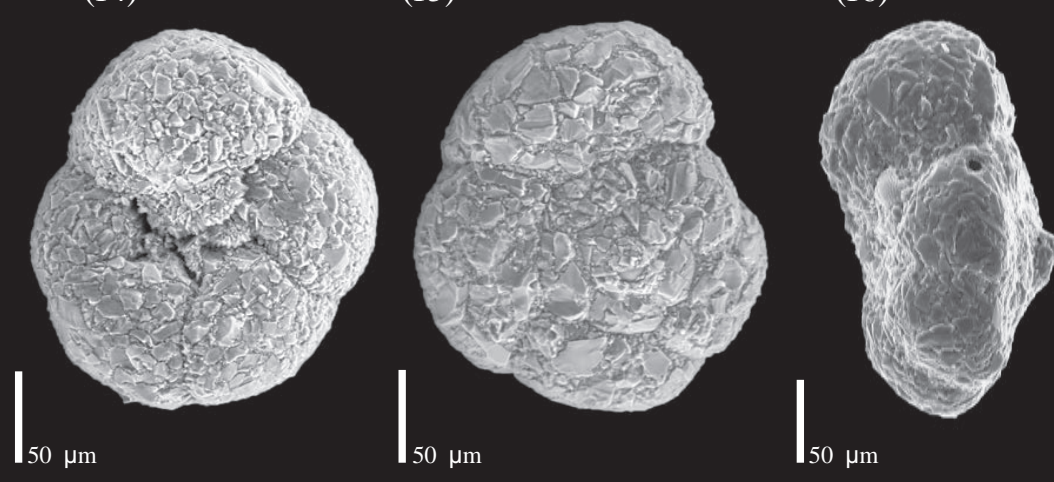

Figure 10. (1-2) Haplophragmoides bradyi niigatensis Uchio (1960) (BC737 (D) 0-1 cm). (3-4) Labrospira sp. 1 (GC666_002). (5) Haplophragmoides quadratus Earland (GC666_002). (6) Glaphyrammina americana (Cushman) (BC738). (7) Glaphyrammina rostrata (HeronAllen and Earland) (BC738). (8) Pseudobolivina antarctica Wiesner (BC737 (D) 4-5 cm). (9-10) Recurvoides sp. 1 (BC667). (1112) Deuterammina scoresbyi Brönnimann and Whittaker (GC666_002). (13) Spiroplectammina biformis (Parker and Jones) (BC738 (D) 9-10 cm). (14-16) Portatrochammina antarctica weisneri (Parr) (GC666_002). (Scale bar $100 \mu \mathrm{m}$ unless otherwise indicated.) 
Material. Seventeen specimens from 10 samples.

Description. Slender, elongate, slightly arched test comprising two to four chambers; final chamber large, tapering, and fusiform. Chambers increase rapidly in size; final chamber often comprising the majority of the test; depressed sutures; wall comprises poorly sorted sand grains in firm cement, coarsely finished. Large, round terminal aperture on a short neck.

Occurrence. This species was originally described by Earland (1933) from a number of stations near South Georgia. The description was subsequently emended by Höglund (1947) using specimens from the North Sea. Earland (1934) also reported its occurrence around the Falkland Islands, where it is widely distributed but rare at most localities. Kaminski and Gradstein (2005) report that $R$. subfusiformis is reported from Recent sediments at high-latitude stations throughout the Atlantic and Southern Oceans.

\section{Family Hormosinidae Haeckel, 1894}

Subfamily Hormosininae Haeckel, 1894

Genus Pseudonodosinella Saidova, 1970

\section{Pseudonodosinella sp.}

(Fig. 9:15)

Material. One specimen from one sample.

Description. Elongate, uniserial test; ovate chambers that overlap much of the preceding chamber, including the aperture. Firmly agglutinated, smoothly finished wall; terminal aperture.

\section{Family Haplophragmoididae Maync, 1952}

Genus Haplophragmoides Cushman, 1910

Haplophragmoides bradyi Robertson subsp. niigatensis Uchio, 1962

(Fig. 10:1-2)

1962 Haplophragmoides bradyi (Robertson) subsp. niigatensis Uchio: 385, pl. 18, fig. 6.

1975 Haplophragmoides bradyi (Robertson); Anderson: 76, pl. 2 , fig. 8 .

Material. Seventeen specimens from six samples.

Description. Small, subglobose, involute test; becomes slightly evolute and umbilicate in adult tests; rounded periphery, slightly lobulate. Chambers low and broad, somewhat inflated; five in final whorl, gradually increasing in size as added. Distinct, depressed, radiate sutures. Finely agglutinated wall with smooth surface, yellowish colour. Aperture an interiomarginal crescentic slit.

Occurrence. Originally described from Recent sediments from the Sea of Japan (Uchio, 1962), it was subsequently recorded from the Weddell Sea (Anderson, 1975).

Remarks. Haplophragmoides bradyi niigatensis Uchio differs from Haplophragmoides bradyi (Robertson) in having a less evolute and more inflated test.

Haplophragmoides quadratus Earland, 1934

(Fig. 10:5)

1934 Haplophragmoides quadratus Earland: 88, pl. 3, figs. 7-8.

1960 Haplophragmoides quadratus Earland; Uchio: 52, pl. 1, fig. 17, pl. 5, fig. 14 .

Material. Forty-three specimens from seven samples.

Description. Planispiral, compressed test with rounded periphery; approximately square outline with rounded corners. Chambers globose, slightly inflated; four in final whorl. Distinct, depressed sutures. Aperture not clearly visible in the specimens examined here.

Occurrence. Originally described from Bellingshausen Sea, Antarctica (Earland, 1932).

Remarks. Haplophragmoides quadratus Uchio 1960 , described from the Pacific coast of the USA, appears to be the same species and would therefore be a junior synonym.

Genus Labrospira Höglund, 1947

Labrospira scitula (Brady, 1881)

(Fig. 9:16-18)

1881 Lituola (Haplopragmium) scitulum Brady: 50, pl. 34, figs $11-13$.

1933 Haplophragmoides scitulum (Brady); Earland: 78, pl. 3, figs. 11-12.

1994 Veleroninoides scitulus (Brady); Jones: 41, pl. 34, fig. 13.

? 1996 Recurvoides contortus Violanti: 39, pl. 4, fig. 11.

2017 Veleroninoides scitulus (Brady); Kender and Kaminski: pl. 8 , fig. 10 .

Material. Overall, 328 specimens from 25 samples.

Description. Planispiral, partially evolute test, comprising three whorls with 8-11 chambers in the final whorl. Some specimens become slightly streptospiral in the final 
whorl; fairly deep umbilicus on both sides. Sutures slightly curved to straight, radial, and very slightly depressed. Smooth-surfaced, thick agglutinated wall comprising coarse grains with yellow-brown cement; colour rapidly fades to white after death. Aperture an elongate oval-shaped areal opening, close to the base of the apertural face, with a fine-grained, raised lip surrounding the aperture.

Occurrence. Originally described from the North Atlantic (Brady, 1881); also recorded from the Bering Sea (Kender and Kaminski, 2017).

Remarks. Labrospira scitula (Brady) is also often placed within the genus Veleroninoides. However, we believe this designation to be incorrect as L. scitula (Brady) is not fully evolute - a diagnostic characteristic of Veleroninoides.

\section{Labrospira sp. 1}

(Fig. 10:3-4)

Material. Overall, 236 specimens from 26 samples.

Description. Planispiral, slightly evolute test; slightly inflated chambers; six in the final whorl. Small umbilicus; straight, radial, slightly depressed sutures; smooth surface; thick agglutinated wall comprising coarse grains with yellow-brown cement. Aperture an areal, elongate slit, close to the base of the apertural face, with a very fine-grained, raised lip surrounding the aperture.

Remarks. Our material may represent the same species as that recorded by Murray and Pudsey (2004) as Haplophragmoides canariensis (d'Orbigny). We consider that this classification is incorrect, however, due to the significant differences in apertural characteristics.

\section{Family Discamminidae Mikhalevich, 1980}

Genus Glaphyrammina Loeblich \& Tappan, 1984

Glaphyrammina americana (Cushman, 1910)

(Fig. 10:6)

1910 Ammobaculites americanus Cushman; 117, figs. 184185.

1932a Ammobaculites americanus Cushman; Heron-Allen \& Earland: 341, pl. 8, figs. 15-17.

1994 Glaphyrammina americana (Cushman); Jones: 40, pl. 34, figs. 1-4.

Material. Six specimens from four samples.

Description. Very large broad and flattened test, initially planispiral becoming uniserial; spiral section slightly involute; nine chambers in the outer whorl. Wall comprises well-cemented, poorly sorted sand grains and occasional diatom frustules. Long, slit-like aperture extends the width of the final chamber.

Occurrence. Originally described off the west coast of Mexico (Cushman, 1910), later from the South Atlantic (Jones, 1994).

Glaphyrammina rostrata (Heron-Allen and Earland, 1929)

(Fig. 10:7)

1929 Ammobaculites rostratus Heron-Allen \& Earland; 326, pl. 2, figs. 14-17.

1933 Ammobaculites rostratus Heron-Allen \& Earland; Earland: 80, pl. 5, figs. 22-25.

Material. Overall, 278 specimens from 23 samples.

Description. Thin-walled, flattened, planispiral test. Sutures often indistinct, especially in smaller specimens; approximately six chambers in final whorl, partially evolute. In some specimens the chambers begin to uncoil to have two uniserial chambers; where this uncoiling does not occur the final chamber protrudes at an angle away from the spiral. The test is constructed of fine sand with larger grains distributed throughout this matrix. The final chamber terminates with a narrowing apertural neck, described as "nipple-like" in Heron-Allen and Earland (1929) that is much more neatly constructed, solely comprising fine sand (this structure is very fragile and often partially or completely absent).

Occurrence. This species has been described from the South Georgia region (Heron-Allen and Earland, 1929; Earland, 1933).

Remarks. Originally described by Heron-Allen and Earland (1929) within the genus Ammobaculites, here we place this species in the genus Glaphyrammina due to the flattened nature of the test. When the apertural neck is absent the specimens can resemble Glaphyrammina americana but can be separated by the less distinct sutures.

Family Ammosphaeroidinidae Cushman, 1927

Subfamily Recurvoidinae Alekseychik-Mitskevich, 1973

Genus Recurvoides Earland, 1934

Recurvoides sp. 1

(Fig. 10:9-10)

Material. Five specimens from three samples. 
Description. Involute, subglobose test, streptospirally coiled in early stage, becoming planispiral. Broad, low chambers. Agglutinated wall, with a fairly rough surface. Simple, areal, aperture, just above the base of the final chamber.

Remarks. These specimens are placed in the genus Recurvoides on the basis of wall and apertural characteristics. Due to their small size, it has not been possible to definitively identify the coiling pattern.

Family Spiroplectamminidae Cushman, 1927

Subfamily Spiroplectammininae Cushman, 1927

Genus Spiroplectammina Cushman, 1927

Spiroplectammina biformis (Parker and Jones, 1865)

(Fig. 10:13)

1865 Textularia agglutinans var. biformis Parker \& Jones: 370, pl. 15, figs. 23-24.

1932a Spiroplectammina biformis (Parker \& Jones); HeronAllen \& Earland: 347, pl. 8, figs. 27-31.

1994 Spiroplectammina biformis (Parker \& Jones); R. W. Jones: 50, pl. 45, figs. 25-27.

1994 Spiroplectammina biformis (Parker \& Jones); Ishman and Domack: 150, pl. 1, fig. 4.

2003 Spiroplectammina biformis (Parker \& Jones); Gaździcki \& Majewski: 8, fig. 4 (5).

2005 Spiroplectammina biformis (Parker \& Jones); Majewski: 195, fig. 14 (3-5).

2009 Spiroplectammina biformis (Parker \& Jones); Majewski \& Anderson: 138, fig. 3.

2013 Spiroplectammina biformis (Parker \& Jones); Rodrigues et al.: 214 , fig. 3 (9).

Material. One specimen from one sample.

Description. Small test mainly comprising sand grains with a small amount of cement. Initially planispiral, rapidly uncoiling and becoming biserial; coiled section broader than biserial section; biserial chambers are subquadrate. Aperture a low arch at the inner margin of the final chamber.

Occurrence. Originally described from Recent sediments from Greenland (Parker and Jones, 1865) and later from the Arctic (Goes, 1894; Höglund, 1947). More recently this species has been described from the Antarctic Peninsula (Ishman and Domack, 1994; Majewski, 2005, 2013).

Remarks. The type species of Spiroplectammina. The large geographical separation between these two areas suggests that the Antarctic form may be a different species but they are morphologically very similar. Also recorded from the Cretaceous Chalk and Gault of England by Parker and Jones (1865), who suggest it is an abbreviated form of Textularia annectens, which is commonly found within the Cretaceous.

Family Pseudobolivinidae Wiesner, 1931

Genus Pseudobolivina Wiesner, 1931

Pseudobolivina antarctica Wiesner, 1931

(Fig. 10:8)

1931 Pseudobolivina antarctica Wiesner: 99, pl. 21, figs. 257-258.

1975 Pseudobolivina antarctica Wiesner; Anderson: 78, pl. 3, fig. 4.

1981 Pseudobolivina antarctica Wiesner; Milam \& Anderson: 305 , pl. 3, fig. 7 .

1990 Pseudobolivina antarctica Wiesner; Mackensen et al.: 258, pl. 5, fig. 7.

1996 Pseudobolivina antarctica Wiesner; Violanti, 55, pl. 4, figs. 12-13.

Material. Twenty-three specimens from 11 samples.

Description. Very small biserial test, tapered at the base; chambers rapidly enlarging as they are added to give broad maximum width. Wall comprises fine sand with little cement such that the surface is fairly rough. Sutures clearly visible and slightly depressed. Aperture loop-shaped extending up the face of the final chamber.

Occurrence. Originally described from Antarctica (Wiesner, 1931) and subsequently recorded in Recent sediments from a number of locations on the Antarctic shelf (Anderson, 1975; Milam and Anderson, 1981; Mackensen et al., 1990; Violanti, 1996).

Remarks. Pseudobolivina antarctica is also described in Igarashi et al. (2001) and Majewski (2013). However, the slit-like aperture shown by these authors does not agree with the type description, suggesting it has been incorrectly assigned (these specimens may be Textularia antarctica).

Family Trochamminidae Schwager, 1877

Subfamily Trochammininae Schwager, 1877

Genus Portatrochammina R. J. Echols, 1971

Portatrochammina antarctica weisneri (Parr, 1950)

(Fig. 10:14-16)

1950 Trochammina wiesneri Parr: 279, pl. 5, fig. 14.

1975 Portatrochammina wiesneri (Parr); Anderson: 92, pl. 3, fig. 5.

1988 Portatrochammina antarctica wiesneri (Parr); Brönnimann \& Whittaker: 68, figs. 25D-F, 26H-K, 27D-I. 
1994 Portatrochammina antarctica (Parr); Ishman \& Domack: 150 , pl. 1 , fig. 5 .

1996 Portatrochammina antarctica (Parr); Violanti: 55, pl. 4, figs. 14-15.

2001 Portatrochammina antarctica antarctica (Parr); Igarashi et al.: 145, pl. 4, fig. 6.

2004 Portatrochammina antarctica (Parr); Murray \& Pudsey: 71, pl. 1, figs. 14-16.

2009 Portatrochammina antarctica (Parr); Majewski \& Anderson: 138, fig. 3.

2013 Portatrochammina antarctica (Parr); Majewski: 178, fig. 6(4).

Material. Overall, 383 specimens from 31 samples.

Description. Low, trochospiral test of approximately 17 chambers, slightly convex on the spiral side and shallowly concave on the umbilical side; three whorls with five chambers in the final whorl. Well-defined, moderately depressed sutures producing slightly lobate outline. Periphery sub-acute in edge view. Aperture covered by a large umbilical flap that covers much of the umbilical depression (diagnostic of this genus); parts of the apertural flaps of preceding chambers also visible. Agglutinated, imperforate wall, coarser on spiral side. Yellowish-brown colour that is markedly darker (almost reddish) in earlier chambers.

Occurrence. Originally described from Antarctica (Parr, 1950) and subsequently recorded from around Antarctica (Anderson, 1975; Brönnimann and Whittaker, 1988; Ishman and Domack, 1994; Violanti, 1996; Igarashi et al., 2001; Murray and Pudsey, 2004; Majewski and Anderson, 2009; Majewski, 2013).

Remarks. Portatrochammina antarctica wiesneri (Parr) can be distinguished from Portatrochammina antarctica antarctica (Parr) by its flatter, smoother test and subacute peripheral margin.

\section{Subfamily Polystomammininae Brönnimann \&} Beurlen, 1977

Genus Deuterammina Brönnimann, 1976

Deuterammina scoresbyi Brönnimann \& Whittaker, 1988

(Fig. 10:11-12)

1988 Deuterammina scoresbyi Brönnimann \& Whittaker: 116, fig. 43(A-J).

Material. Overall, 207 specimens from 26 samples.

Description. Low trochospiral test, becoming planispiral in the final whorl; spiral side slightly depressed centrally; deep wide umbilical depression. Sutures distinct, straight, radial, slightly depressed; 20 chambers including the proloculus arranged in three whorls; six to seven slightly inflated chambers in the final whorl. Primary aperture interiomarginal, sub-peripheral loop-shape that widens towards the spiral side with a lip; secondary aperture at umbilical tip of chamber, may have a lip; both apertures present on every chamber. Agglutinated, imperforate wall.

Occurrence. Originally described from the Bellingshausen Sea and the South Sandwich Islands (Brönnimann and Whittaker, 1988).

Remarks. Brönnimann and Whittaker (1988) describe the wall as being almost entirely composed of barite spherules/ovoids. This is not the case in the specimens described here, although some ovoids were observed. Additionally the specimens described here have six to seven chambers in the final whorl, rather than the eight described in Brönnimann and Whittaker (1988).

Subfamily Trochamminellinae Brönnimann, Zaninetti \& Whittaker, 1983

Genus Pseudotrochammina Frerichs, 1969

Pseudotrochammina sp. 1

(Fig. 11:1)

Material. Overall, 182 specimens from 21 samples.

Description. Low trochospiral test; globular chambers that rapidly increase in size; four in final whorl. Depressed sutures; smoothly finished, finely agglutinated wall; areal elongate slit aperture located on the umbilical side but not in the umbilicus.

Family Cyclamminidae Marie, 1941

Subfamily Cyclammininae Marie, 1941

Genus Cyclammina Brady, 1879

Cyclammina cf. contorta Pearcey, 1914

(Fig. 11:2)

1914 Cyclammina contorta Pearcey: 1009, pl. 2, figs. 5-7.

Material. One specimen from one sample.

Description. Very large, planispiral, involute, somewhat compressed test; rounded periphery; very slightly lobulate margin. Numerous chambers (ca. 15) in the final whorl; sutures straight. Finely agglutinated, surface smooth, slightly iridescent. Aperture appears to be an interiomarginal, equatorial low arch, although this is poorly preserved on the only specimen found in this study. Apertural face of the final 


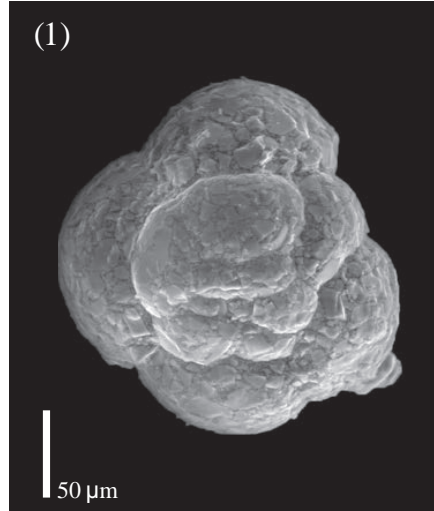

(6)
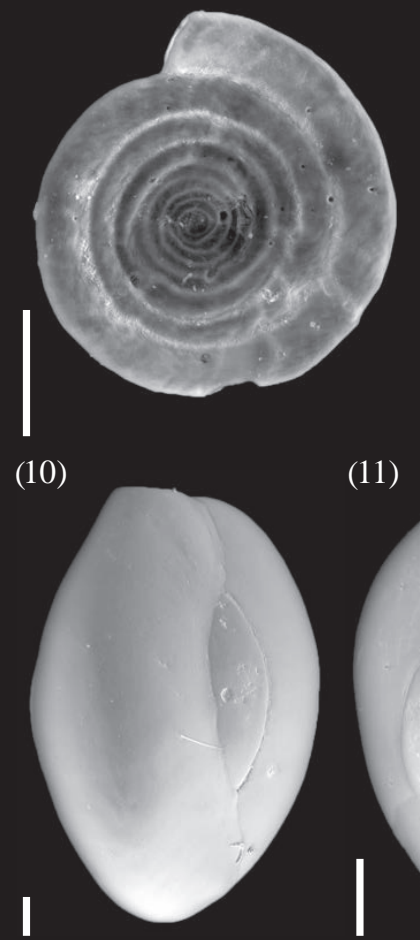

(14)

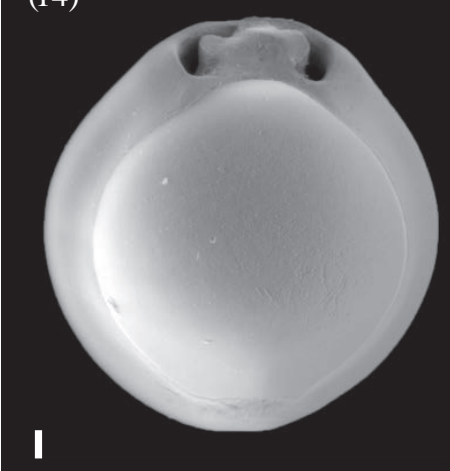

(11)
(2)

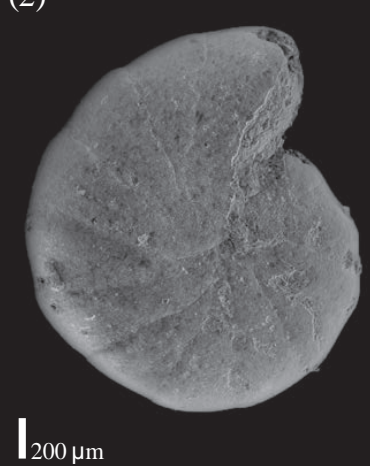

(7)

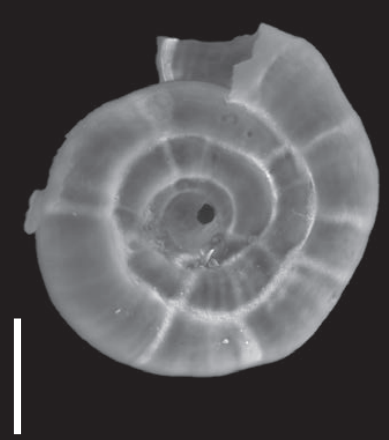

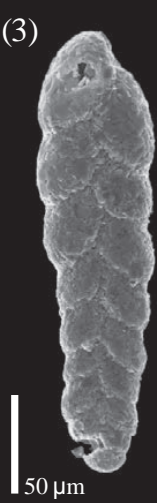

(8)

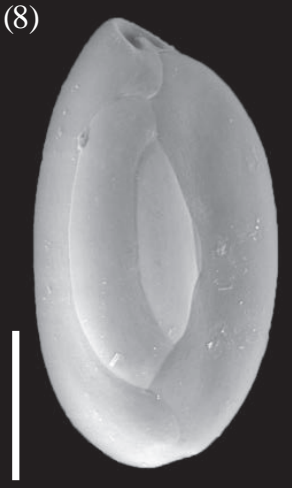

(4)

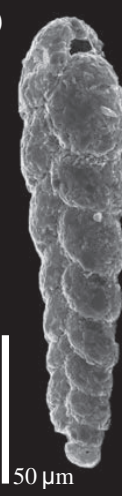

(5)

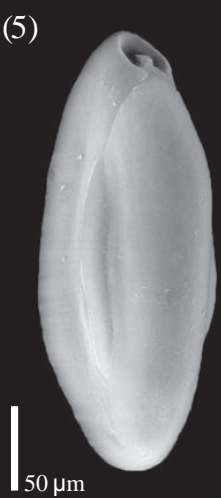

(9)

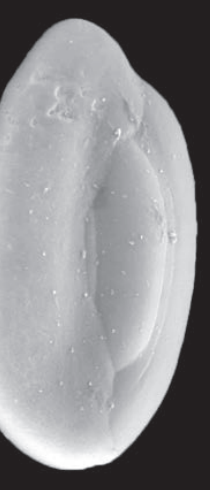

(12)

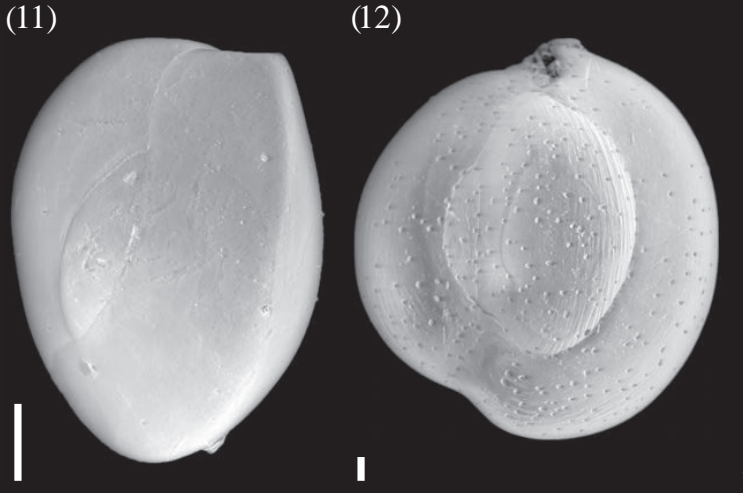

(13)

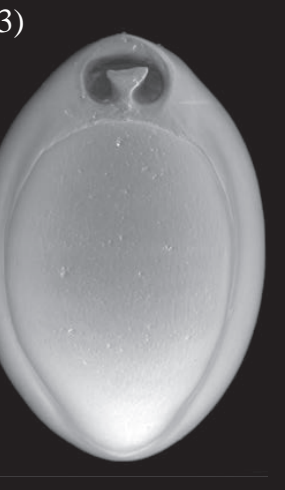

(15)

(16)

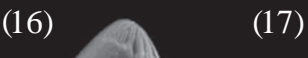

(17)

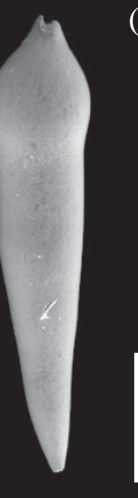

(18)

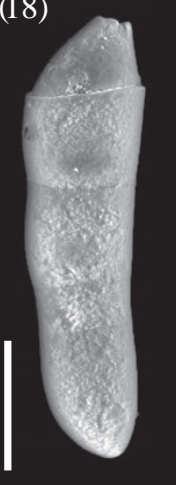

Figure 11. (1) Pseudotrochammina sp. 1 (BC737 (D) 0-1 cm). (2) Cyclammina cf. contorta Pearcey (BC667). (3-4) Textularia earlandi Parker (GC666_002). (5 and 8-9) Quinqueloculina cf. occidentalis Bailey (BC738). (6-7) Cornuspira antarctica Rhumbler (BC671; GC666_002). (10-11) Quinqueloculina seminula (Linnaeus) (BC737 (D) 0-1 cm; BC737 (D) 3-4 cm). (12) Quinqueloculina cf. sublineata (Brady) (BC671). (13) Pyrgo patagonica (d'Orbigny) (GC673_544). (14) Pyrgo cf. subpisum Parr (1950) (GC673_544). (15) Triloculina sp. (BC737 (D) 0-1 cm). (16) ? Astacolus sp. (BC671). (17-18) Laevidentalina communis (d'Orbigny) (GC666_002; BC737 (D) 3-4 cm). (Scale bar $100 \mu \mathrm{m}$ unless otherwise indicated.) 
chambers much more coarsely agglutinated with a rough surface; no evidence of additional apertures.

Occurrence. Cyclammina contorta Pearcey was originally described from the Weddell Sea, Antarctica.

Remarks. The species described here differs only in its sutural characteristics, being straighter and less dark in colour.

Family Textulariidae Ehrenberg, 1838

Subfamily Textulariinae Ehrenberg, 1838

Genus Textularia Defrance, 1824

Textularia earlandi Parker, 1952

(Fig. 11:3-4)

1933 Textularia tenuissima Earland: 95, pl. 3, figs. 21-30. 1952 Textularia earlandi Parker: 458 (see synonymy). 1996 Textularia earlandi Parker; Violanti: 57, pl. 5, figs. 1314.

2010 Textularia tenuissima Earland; Majewski: 65, fig. 2(2).

Material. Forty-nine specimens from 18 samples.

Description. Very small, delicate, elongate test. Initial chambers coiled in both microspheric (tapered end) and megalospheric (rounded end) forms, becoming biserial. Numerous subquadrate, rounded chambers that enlarge slightly towards the terminal end. Distinct, slightly depressed sutures. Aperture a low interiomarginal arch on the face of the final chamber. Fairly smooth wall comprising fine grains with little cement visible.

Occurrence. Originally described from South Georgia (Earland, 1933); subsequently recorded from the Ross Sea (Violanti, 1996) and the Antarctic Peninsula (Majewski, 2010).

Remarks. Originally described from South Georgia as Textularia tenuissima Earland, this was however preoccupied by Textularia tenuissima Häusler 1881. Therefore, Parker (1952) proposed the new name Textularia earlandi. Morphologically it is very similar to Textularia elegans Lacroix, found in the Mediterranean.

Family Cornuspiridae Schultze, 1854

Subfamily Cornuspirinae Schultze, 1854

Genus Cornuspira Schultze, 1854

Cornuspira antarctica Rhumbler in Wiesner, 1931 (Fig. 11:6-7)
1931 Cornuspira antarctica Rhumbler in Wiesner: 101, pl. 14, figs. 164-166.

Material. Two specimens from two samples.

Description. Discoidal test comprising two chambers, the globular proloculus and the planispirally enrolled, undivided, near-evolute second chamber. Calcareous, imperforate, porcellaneous wall with transverse growth lines. Aperture simple opening at end of tube.

Occurrence. Originally described from Antarctica (Wiesner, 1931).

Family Hauerinidae Schwager, 1876

Subfamily Hauerininae Schwager, 1876

Genus Quinqueloculina d'Orbigny, 1826

Quinqueloculina cf. occidentalis Bailey, 1851

(Fig. 11:5 and 11:8-9)

1851 Quinqueloculina occidentalis Bailey: 13, figs. 46-48.

2013 Quinqueloculina sp. Majewski: 179, fig. 7 (6).

2013 Quinqueloculina seminula (Linnaeus); Rodrigues et al.: 214, fig. 3 (6-7).

Material. Twenty-one specimens from seven samples.

Description. Small, elongate, subovate test, quinqueloculine chamber arrangement, rounded periphery, long, narrow chambers that rapidly increase in size as added. Calcareous, smooth, thin, porcellaneous wall; distinct, somewhat depressed sutures; aperture a terminal high arch with a small tooth.

Occurrence. Quinqueloculina occidentalis Bailey was originally described from the North Atlantic. Similar specimens have been recorded from Antarctica (Majewski, 2013; Rodrigues et al., 2013) but never previously assigned to $Q$. occidentalis Bailey.

Remarks. The specimens described here appear quite similar to Quinqueloculina occidentalis Bailey, although the very brief original description hinders any certainty in this designation. The specimens also share a number of features with Triloculinella antarctica Kennett, but the absence of a broad apertural flap indicates that this species does not belong within the genus Triloculinella; its placement within this genus by Majewski (2005) is therefore incorrect.

Quinqueloculina seminula (Linnaeus, 1758)

(Fig. 11:10-11) 
1758 Serpula seminulum Linnaeus: 786, pl. 2, fig. 1. 1932a Miliolina seminulum (Linnaeus); Heron-Allen \& Earland: 313, pl. 6, figs. 25-40.

1981 Quinqueloculina seminulum (Linnaeus); Milam and Anderson: 307, pl. 5, fig. 5.

1994 Quinqueloculina seminulum (Linnaeus); Jones: 21, pl. 5, fig. 6, text figs. 2-3.

2013 Quinqueloculina seminulum (Linnaeus); Rodrigues et al.: 214, fig. 3 (6-7).

Material. Two specimens from two samples.

Description. Slightly compressed ovate test, rounded at base, more angular at apertural end, rounded triangular in section. Quinqueloculine coiling; five chambers visible in final whorl, four from one side and three from the other; more convex on the four-chambered side. Calcareous, imperforate, porcellaneous wall; smooth surface. Large, terminal, horseshoe-shaped aperture with a small bifid tooth.

Occurrence. Recorded from the North Atlantic in the Challenger material (Jones, 1994) and from Antarctica by Milam and Anderson (1981).

Quinqueloculina cf. sublineata (Brady, 1884) (Fig. 11:12)

1884 Miliolina circularis var. sublineata Brady: 169, pl. 4, fig. 7.

1994 Triloculinella sublineata (Brady); R. W. Jones: 20, pl. 4 , fig. 7 .

Material. One specimen from one sample.

Description. Test near-circular in outline; compressed, rounded section. Quinqueloculine coiling; five chambers visible in final whorl; calcareous, imperforate, porcellaneous wall; terminal, low, broad, arch-shaped aperture. Surface ornamented with very delicate, longitudinal striae and large pits.

Remarks. The absence of an apertural flap in the specimen described here, and in the image of Jones (1994), plus the presence of five chambers in the final whorl, leads us to place it within Quinqueloculina. This specimen differs from the specimen figured in Brady (1884) and Jones (1994) in the presence of large pits that cover its surface.

Genus Pyrgo Defrance, 1824

Pyrgo cf. subpisum Parr, 1950

(Fig. 11:14)

1950 Pyrgo subpisum Parr: 297, pl. 7, figs. 5-6.
Material. One specimen from one sample.

Description. Large, subglobular test, near-circular from front, rounded periphery; two chambers visible in final whorl (biloculine). Calcareous, imperforate, porcellaneous wall; large, ovate, terminal aperture, surrounded by a thickened, raised rim; unusual large tooth with three lobes.

Occurrence. Pyrgo subpisum Parr was described from a number of locations in the southern Indian Ocean.

Remarks. The specimen described here is very similar to Pyrgo subpisum Parr, differing only in the unusual tooth characteristics.

Pyrgo patagonica (d'Orbigny, 1839b)

(Fig. 11:13)

1839b Biloculina patagonica d'Orbigny: 65, pl. 3, figs. 1517.

1932a Biloculina patagonica d'Orbigny; Heron-Allen \& Earland: 311, pl. 6, figs. 4-6.

2004 Pyrgo patagonicum (d'Orbigny); Mikhalevich: 188, pl. 3, figs. 6-7.

Material. One specimen from one sample.

Description. Large, subglobular test, ovate from front, rounded periphery; two inflated chambers visible in final whorl (biloculine). Calcareous, imperforate, porcellaneous, think wall, with a smooth, shiny surface; medium, round, terminal aperture, surrounded by a small, thickened, raised rim; bifid tooth.

Occurrence. Originally described from the Patagonian coast (d'Orbigny, 1839b).

Genus Triloculina d'Orbigny, 1826

Triloculina sp.

(Fig. 11:15)

Material. Twenty-three specimens from 11 samples.

Description. Ovate text, triangular in section with rounded corners; triloculine, three chambers visible in final whorl. Chambers slightly inflated; sutures somewhat depressed; calcareous, imperforate, porcellaneous wall; smooth surface. Terminal, rounded aperture; no tooth visible.

Family Nodosariidae Ehrenberg, 1838

Subfamily Nodosariinae Ehrenberg, 1838

Genus Laevidentalina Loeblich \& Tappan, 1986 
Laevidentalina communis (d'Orbigny, 1826)

(Fig. 11:17-18)

1826 Nodosaria (Dentalina) communis d'Orbigny: 254 (no type figure).

1996 Dentalina communis (d'Orbigny); Violanti: 59, pl. 6, fig. 11.

2005 Dentalina communis (d'Orbigny); Majewski: 201, fig. 20(2-3).

2013 Laevidentalina communis (d'Orbigny); Majewski: 181, fig. 9(2).

Material. Two specimens from two samples.

Description. Elongate, slightly arcuate test; fusiform, apiculate proloculus, followed by a number of uniserially arranged chambers; straight, horizontal sutures. Calcareous, hyaline, finely perforate wall; smooth surface; multilamellar, terminal aperture damaged in our specimens.

Occurrence. Recorded from Antarctica in Recent sediments (Violanti, 1996; Majewski, 2005, 2013)

Remarks. Placed within the genus Laevidentalina due to the absence of costae.

Genus Lotostomoides Hayward \& Kawagata, 2012

Lotostomoides calomorphum (Reuss, 1866)

(Fig. 12:1-2)

1866 Nodosaria (Nodosaria) calomorpha Reuss: 129, pl. 1, figs. 15-19.

1933 Nodosaria calomorpha Reuss; Earland: 117, pl. 4, fig. 19.

1994 Glandulonodosaria calomorpha (Reuss); Jones: 72, pl. 61, figs. 23-26.

Material. Six specimens from four samples.

Description. Small, elongate, slightly arcuate test comprising two to four sausage-shaped chambers. Simple, round, terminal aperture. Thin, hyaline, calcareous wall, with smooth surface; sutures straight and horizontal.

Occurrence. Reported from South Georgia (Earland, 1933) and the South Atlantic (Jones, 1994).

Genus Nodosaria Lamarck, 1812

Nodosaria simplex Silvestri, 1872

(Fig. 12:3-4)

1872 Nodosaria simplex Silvestri: 95, pl. 11, figs. 268-272. 1994 Nodosaria simplex Silvestri; Jones: 73, pl. 62, figs. 4-5.
Material. Two specimens from two samples.

Description. Small, slightly elongate test comprising two spherical/ovate chambers of approximately the same size; straight, depressed suture between the chambers. Both chambers narrow terminally: the upper towards the aperture, whilst the lower becomes apicate. Calcareous, hyaline, perforate wall, smooth and unornamented. Terminal, rounded aperture with radiating grooves.

Family Vaginulinidae Reuss, 1860

Subfamily Lenticulininae Chapman, Parr \& Collins, 1934

Genus Lenticulina Lamarck, 1804

Lenticulina asterizans Parr, 1950

(Fig. 12:5)

1950 Lenticulina (Robulus) asterizans Parr: 322, pl. 11, figs. 9-10.

Material. One specimen from one sample.

Description. Planispiral, involute, lenticular test; narrow rounded keel on periphery; eight chambers in final whorl. Limbate, flush sutures; triangular, slightly rounded apertural face; calcareous, hyaline, smooth wall. Aperture damaged in the specimen described here.

Occurrence. Originally described from Antarctica (Parr, 1950).

Subfamily Marginulininae Wedekind, 1937

Genus Astacolus de Montfort, 1808

\section{? Astacolus sp.}

(Fig. 11:16)

Material. One specimen from one sample.

Description. Elongate, flattened test; low, broad chambers added on a slightly curved axis; strongly oblique, curved sutures; rounded periphery; smooth, perforate, calcareous wall; terminal, radiate aperture.

Family Lagenidae Reuss, 1862

Genus Lagena Walker \& Jacob in Kanmacher, 1798

Lagena substriata Williamson, 1848

(Fig. 12:6-7) 

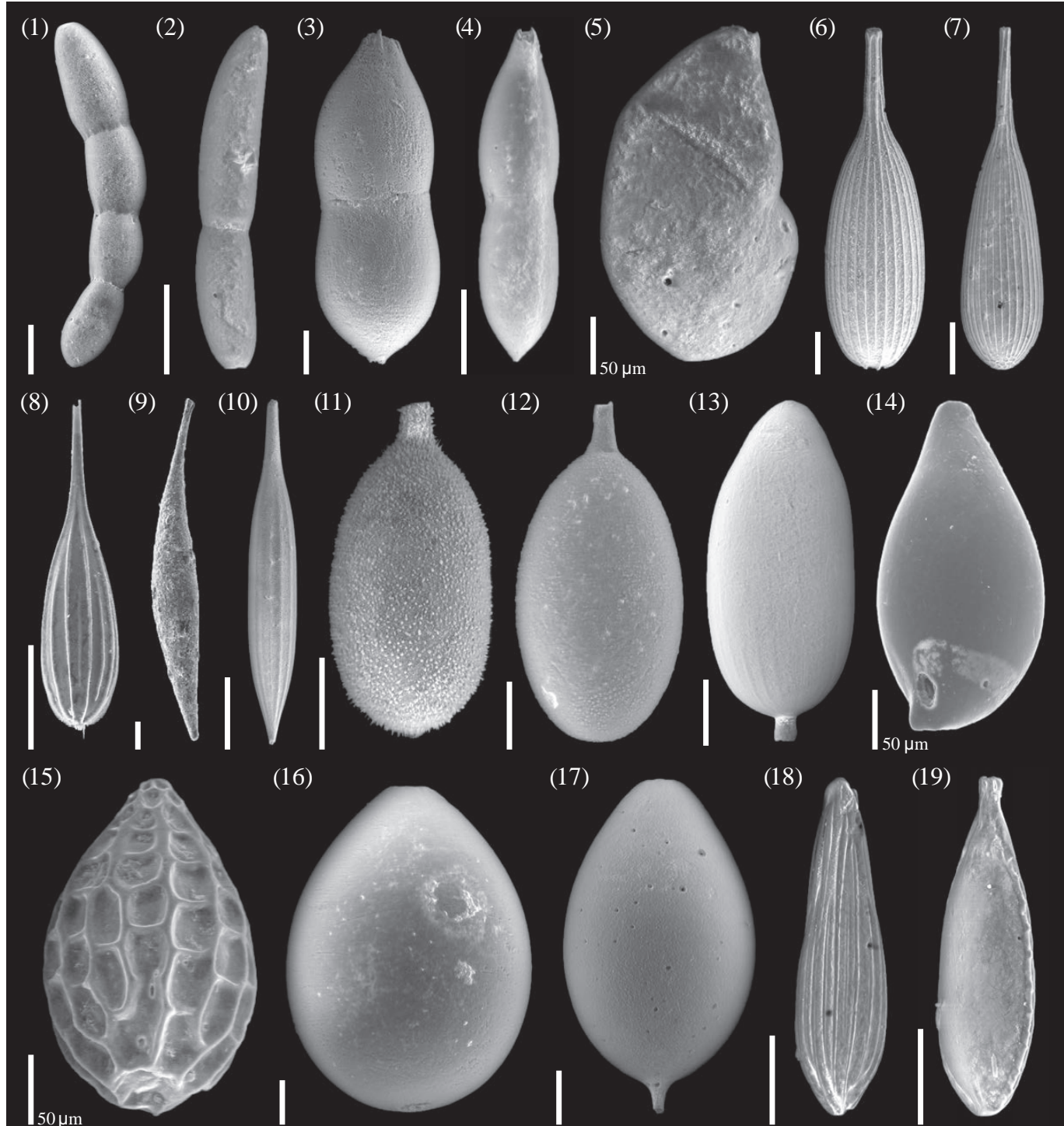

(16)

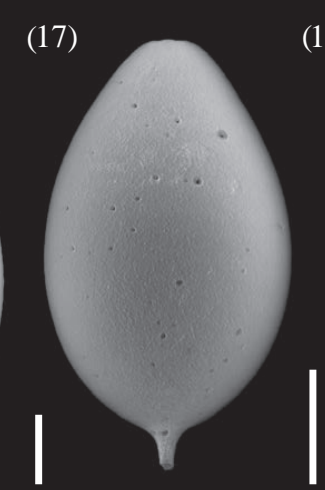

(18)
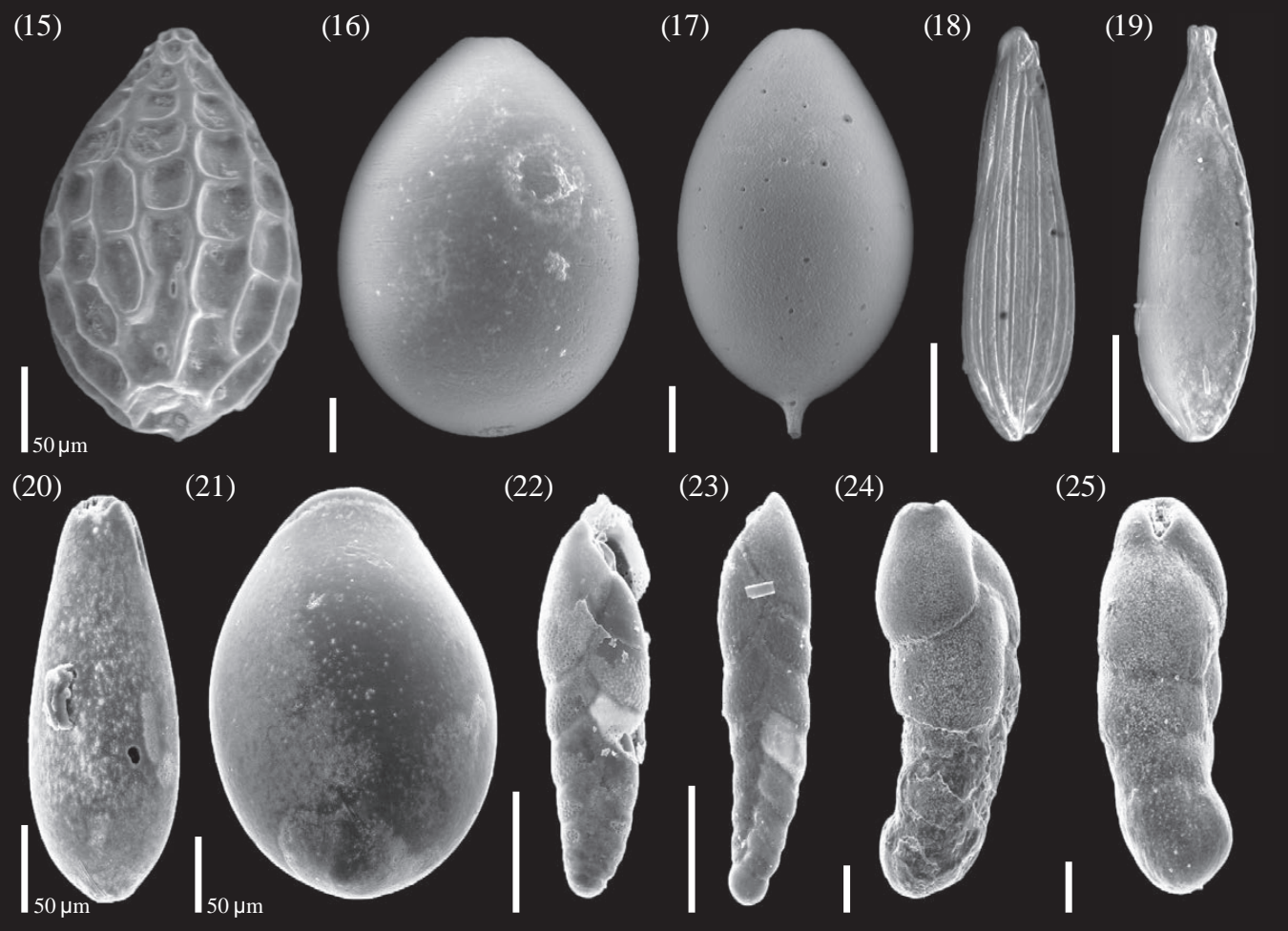

(23)

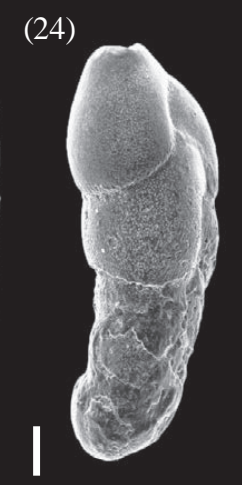

(25)
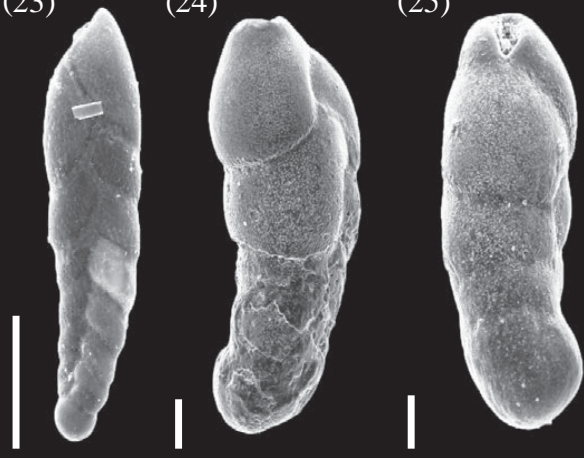

Figure 12. (1-2) Lotostomoides calomorphum (Reuss) (BC737 (D) 2-3 cm). (3-4) Nodosaria simplex Silvestri (GC666_119; GC666_159). (5) Lenticulina asterizans Parr (GC666_127). (6-7) Lagena substriata Williamson (BC737 (D) 4-5 cm; BC738 (D) 5-6 cm). (8) Lagena multilatera McCulloch (GC666_002). (9) Hyalinonetrion cf. gracillimum (Seguenza) (GC666_295). (10) Procerolagena distoma (Parker and Jones M.S.) (GC666_127). (11) Pygmaeoseistron hispidulum (Cushman) (BC738). (12) Pygmaeoseistron sp. (BC738 (D) 2-3 cm). (13) Oolina spp. (BC738 (D) 8-9 cm). (14) Fissurina sp. 1 (GC666_002). (15) Favulina squamosa (Montagu) (GC666_124). (16-17) Oolina globosa (Montagu) (BC737; BC738 (D) 3-4 cm). (18) Vasicostella striatopunctata (Parker and Jones) (BC660). (19) Fissurina subformosa Parr (BC737 (D) 2-3 cm). (20) Fissurina sp. 2 (GC666_002). (21) Parafissurina fusiformis Wiesner (GC666_002). (22) Bolivinellina earlandi (Parr) (GC666_002). (23) Bolivinellina pseudopunctata (Höglund) (GC666_002). (24-25) Cassidulinoides parkerianus (Brady) (GC666_002). (Scale bar $100 \mu \mathrm{m}$ unless otherwise indicated.) 
1848 Lagena substriata Williamson: 15, pl. 2, fig. 12. 1994 Lagena substriata Williamson; Loeblich \& Tappan: 79, pl. 138, figs. 1-5.

2001 Lagena substriata elegantula R. W. Jones; Igarashi et al.: 148 , pl. 7 , fig. 5 .

2009 Lagena weisneri Parr; Majewski \& Anderson: 139, fig. 4.

Material. Four specimens from three samples.

Description. Unilocular, ovate test that may be significantly elongated. Calcareous, hyaline wall ornamented with numerous delicate, parallel, longitudinal costae. Simple aperture with phialine lip at the end of a long neck. Some of the costae continue up the neck, either straight up or spiralling around the neck. Some specimens also present a honeycomb pattern on the base of the test.

Occurrence. Originally described from the Recent of England (Williamson, 1848), this species has also been described from the Timor Sea (Loeblich and Tappan, 1994) and Antarctica (Igarashi et al., 2001; Majewski and Anderson, 2009).

\section{Lagena multilatera McCulloch, 1977}

(Fig. 12:8)

1977 Lagena multilatera McCulloch: 40, pl. 50, fig. 5. 1994 Lagena multilatera McCulloch; Jones: 65, pl. 58, figs. 2-3, 7-8, 22-24.

Material. Five specimens from three samples.

Description. Unilocular, fusiform test. Calcareous, hyaline wall; approximately eight longitudinal costae, high, narrow, tapering, some of which continue onto neck. Small, round, terminal aperture produced on a long delicate neck.

Occurrence. McCulloch (1977) described this species from deep water off Bikini Atoll, Pacific Ocean; subsequently recorded from the South Pacific and Southern Ocean (Jones, 1994).

Genus Hyalinonetrion Patterson \& Richardson, 1987

Hyalinonetrion cf. gracillimum (Seguenza, 1862) (Fig. 12:9)

1862 Amphorina gracillima Seguenza: 51, pl. 1, fig. 37. 1994 Procerolagena gracillima (Seguenza); Jones: 62, pl. 56, figs. 19-22, 24-29.

2005 Hyalinonetrion gracillima (Seguenza); Majewski: 201, fig. 20(7).

2015 Procerolagena gracillima (Seguenza); Setoyama \& Kaminski: 23, fig. 8(28).
Material. Eighteen specimens from five samples.

Description. Fusiform, elongate, unilocular test that slowly tapers at the base. Hyaline, calcareous, unornamented wall. Simple aperture with a phialine lip, at the end of a long, tapering neck.

Occurrence. Originally described from the Miocene of Italy (Seguenza, 1862); subsequently recorded from Recent sediments from Antarctica (Majewski, 2005), the Southern Ocean (Jones, 1994), and the Bering Sea (Setoyama and Kaminski, 2015).

Remarks. Whilst Jones (1994) retained this species in Procerolagena, as he considered Hyalinonetrion to be a junior synonym of Procerolagena, here we place it in Hyalinonetrion due to the absence of any longitudinal ornamentation (Loeblich and Tappan, 1988).

Genus Procerolagena Puri, 1954

Procerolagena distoma (Parker \& Jones M. S. in Brady, 1864)

(Fig. 12:10)

1864 Lagena distoma Parker \& Jones in Brady: 467, pl. 48, fig. 6 .

? 1981 Lagena sulcata var. distomapolita Milam \& Anderson: 308, pl. 6, fig. 2.

1994 Hyalinonetrion distoma (Parker \& Jones); Loeblich \& Tappan: 77, pl. 137, fig. 9.

Material. Thirteen specimens from nine samples.

Description. Unilocular, elongate test with nearly parallel sides in the central part of the test which tapers towards apiculate ends. Calcareous wall ornamented by delicate longitudinal striae.

Occurrence. Originally described from the Shetlands (Brady, 1864); subsequently recorded from Antarctica (Milam and Anderson, 1981) and the Timor Sea (Loeblich and Tappan, 1994).

Remarks. Loeblich and Tappan (1994) assign this species to the genus Hyalinonetrion. However, this designation is in conflict with the genus description in Loeblich and Tappan (1988) defining Hyalinonetrion as unornamented.

Genus Pygmaeoseistron Patterson \& Richardson, 1987

Pygmaeoseistron hispidulum (Cushman, 1913)

(Fig. 12:11)

1913 Lagena hispidula Cushman: 14, pl. 5, figs. 2-3. 
2013 Pygmaeoseistron hispidulum (Cushman 1913); Majewski: 180, fig. 8(11).

Material. Two specimens from two samples.

Description. Unilocular flask-shaped/ovoid test that rapidly narrows to a tubular neck (delicate and often broken, as in figured specimen), evenly covered in fine hispid ornamentation.

Occurrence. Originally described from the North $\mathrm{Pa}$ cific (Cushman, 1913); also recorded from the Amundsen Sea (Majewski, 2013).

\section{Pygmaeoseistron sp.}

(Fig. 12:12)

Material. One specimen from one sample.

Description. Unilocular, ovoid test with a narrow, tubular neck; sporadic pustulose ornamentation.

Remarks. Bears some similarity to Pygmaeoseistron islandicum (Jones, 1994).

Family Ellipsolagenidae A. Silvestri, 1923

Subfamily Oolininae Loeblich \& Tappan, 1961

Genus Favulina Patterson \& Richardson, 1987

Favulina squamosa (Montagu, 1803)

(Fig. 12:15)

1803 Vermiculum squamosum Montagu: 526, pl. 14, fig. 2. 1994 Oolina squamosa (Montagu); Jones: 66, pl. 58, figs. 28-32.

2015 Oolina squamosa (Montagu); Setoyama \& Kaminski: 23 , figs. 7(14), 8(31).

Material. Two specimens from two samples.

Description. Unilocular, ovate test, circular in section, narrowing towards the apertural end. Calcareous, hyaline wall, ornamented with roughly perpendicular vertical costae. Horizontal costae join the vertical to form loosely hexagonal shapes. Round aperture, terminal on a short neck with a rounded lip.

Occurrence. Originally described from Britain (Montagu, 1803); also recorded from the South Pacific (Jones, 1994) and the Bering Sea (Setoyama and Kaminski, 2015).

Remarks. The specimens figured here most closely resemble the specimen from Plate 58, fig. 32, of Jones (1994) from the Challenger material that has previously been variously assigned to Lagena hexagona (Williamson) by Brady (1881) and Thalmann (1932) and Oolina hexagona (Williamson) by Barker (1960), Hermelin (1989), and Van Marle (1991). The ornamentation on our specimens forms roughly perpendicular lines, a feature not seen in Favulina hexagona (Williamson), and it has therefore been assigned to Oolina squamosa (Montagu), following Knight (1986), which is then assigned to the genus Favulina following Clark et al. (1994).

Genus Oolina d'Orbigny, 1839b

Oolina globosa (Montagu, 1803)

(Fig. 12:16-17)

1803 Vermiculum globosum Montagu: 523, pl. 1, fig. 8. 1994 Oolina globosa (Montagu); Jones: 62, pl. 56, figs. 1-3, 15-16.

Material. Two specimens from two samples.

Description. Unilocular, tear-drop shaped test; may have apiculate base. Calcareous, hyaline, smooth wall. Terminal, simple, round aperture, with an entosolenian tube that extends over half the length of the chamber and flares dramatically at the end.

Occurrence. Recorded from the Southern Ocean (Jones, 1994).

Remarks. Following Jones (1994), specimens with an apiculate base are not considered to be distinct from Oolina globosa (Montagu).

\section{Oolina spp.}

(Fig. 12:13)

Material. Eight specimens from four samples.

Description. Included in this group any unilocular, ovate tests with calcareous, hyaline, smooth walls, an apiculate base, and a rounded terminal aperture that have not been assigned to Oolina globosa (Montagu).

Genus Vasicostella Patterson \& Richardson, 1987

Vasicostella striatopunctata (Parker \& Jones, 1865)

(Fig. 12:18)

1865 Lagena sulcata Walker \& Jones var. striatopunctata Parker \& Jones: 350, pl. 13, figs. 25-27.

2001 Vasicostella striatopunctata (Parker \& Jones); Igarashi et al.: 148 , pl. 8 , fig. 5 .

2013 Vasicostella sp. Majewski: 180, fig. 8 (8). 
Material. One specimen from one sample.

Description. Unilocular, flask-like, compressed test; carinate periphery. Calcareous, hyaline wall, ornamented with strong longitudinal costae that appear striped, perpendicular to their length, due to differences in the optical properties of their calcite (only visible with light microscopy). Rounded, terminal aperture, with a slight lip and a short, centrally placed entosolenian tube.

Occurrence. Parker and Jones (1865) originally described this species from Greenland, the Red Sea, the South Atlantic, and the Indian Ocean. Igarashi et al. (2001) subsequently described it from Antarctica.

Remarks. Le Coze and Hayward (2017) places Lagena striatopunctata Parker \& Jones within the genus Cushmanina. However, we believe that, based on the type figures, this classification is incorrect. The compressed nature of the test and the lack of an elongate neck suggest that this species should be placed within the genus Vasicostella. The specimen described here and that of Igarashi et al. (2001) also reveal the carinate nature of this species, further supporting this classification.

Subfamily Ellipsolageninae A. Silvestri, 1923

Genus Fissurina Reuss, 1850

Fissurina subformosa Parr, 1950

(Fig. 12:19)

1950 Fissurina subformosa Parr: 313, pl. 9, fig. 9. 1996 Lagena subformosa (Parr); Violanti: 43, pl. 7, fig. 3.

Material. Three specimens from three samples.

Description. Small, pyriform test, slightly compressed, tapering towards a long neck; keel extends from the neck around the test, with two tabulated supplementary keels that create a "crimped" appearance. Circular, terminal aperture; straight entosolenian tube extends centrally to approximately one third the length of the chamber.

Occurrence. Previously recorded from Antarctica (Parr, 1950; Violanti, 1996).

Remarks. This species can be distinguished from $F$. formosa (Lagena Formosa Schwager) by the supplementary keels.

Fissurina sp. 1

(Fig. 12:14)

Material. Seven specimens from four samples.
Description. Unilocular, pyriform test, with pointed protuberance towards basal end; circular section. Smooth, hyaline, calcareous wall; terminal, oval aperture within a slightly depressed fissure at the apex of the test.

\section{Fissurina sp. 2}

(Fig. 12:20)

Material. Thirty-one specimens from 15 samples.

Description. Elongate, compressed test, broadening towards the base; rounded ends; base somewhat produced; oval section. Smooth, hyaline, calcareous wall; terminal, slit-like aperture within a significantly depressed fissure at the apex of the test.

Remarks. Bears some similarity to the Oligocene Fissurina oblonga Reuss and to Parafissurina lateralis (Cushman). May have previously been recorded from the Weddell Sea by Anderson (1975) as Parafissurina lateralis (Cushman).

Subfamily Parafissurininae R. W. Jones, 1984

Genus Parafissurina Parr, 1947

Parafissurina fusiformis Wiesner, 1931

(Fig. 12:21)

1931 Parafissurina fusiformis Wiesner: 126, pl. 24, fig. j. 1996 Parafissurina fusiformis Wiesner; Violanti, 62, pl. 8, fig. 8.

2001 Parafissurina fusiformis Wiesner; Igarashi: 151, pl. 9, fig. 5.

2005 Parafissurina fusiformis Wiesner; Majewski: 203, fig. 22(1-2).

Material. Thirty-seven specimens from 14 samples.

Description. Small test, ovate in front view; slightly compressed, rounded periphery. Aperture an elongate slit protected by a protruding hood, with a large lip opposite the hood. Entosolenian tube extends centrally along inner surface of chamber, flaring at the end.

Occurrence. Originally described from high southern latitudes (Wiesner, 1931) and later from other Antarctic localities (Violanti, 1996; Majewski, 2005).

Family Bolivinidae Glaessner, 1937

Genus Bolivinellina Saidova, 1975

Bolivinellina earlandi (Parr, 1950)

(Fig. 12:22) 
1950 Bolivina earlandi Parr: 339, pl. 12, fig. 16. 1996 Bolivina pseudopunctata Höglund; Violanti: 65, pl. 9, fig. 1 .

2001 Bolivinellina earlandi (Parr); Igarashi et al.: 153, pl. 10 , fig. 5 .

2013 Bolivinellina earlandi (Parr); Majewski: 181, fig. 9(4).

Material. Seventy specimens from 19 samples (for Bolivinellina spp.).

Description. Elongate test, biserial throughout, oval in section. Chambers up to 12 in number, slightly inflated; strongly curved, slightly depressed sutures. Wall calcareous, hyaline, smooth; finely perforate in the lower half of the chamber, imperforate in the upper half. Narrow, commashaped aperture starting at the inner margin of the final chamber.

Occurrence. Parr (1950) described this species as widely distributed around Antarctica.

Remarks. Following Igarashi et al. (2001) and Majewski (2013), we have placed this species in the genus Bolivinellina due the lack of perforation in the upper half of the chambers.

Bolivinellina pseudopunctata (Höglund, 1947)

(Fig. 12:23)

1947 Bolivina pseudopunctata Höglund: 273, pl. 24, fig. 5, pl. 32, figs. 23-24.

2005 Bolivina pseudopunctata Höglund; Majewski: 203, fig. 22(6-7).

2013 Bolivinellina pseudopunctata (Höglund); Majewski: 181, fig. 9(3).

Material. Seventy specimens from 19 samples (for Bolivinellina spp.).

Description. Elongate, gently tapering test, biserial from a large globular proloculus, oval in section. Chambers distinct; up to 23 in number; slightly inflated; sutures strongly curved, slightly depressed. Wall calcareous, hyaline, smooth, finely perforate in the lower half of the chamber, imperforate in the upper half. Oval-shaped aperture with a double-folded tongue, starting at the inner margin of the final chamber.

Occurrence. Originally described from the Gullmar Fjord, Sweden (Höglund, 1947), this species has subsequently been described from Antarctica (Majewski, 2005, 2013).

Remarks. Following Majewski (2013) we have placed this species in the genus Bolivinellina due the lack of perforation in the upper half of the chambers. B. pseu- dopunctata can be distinguished from $B$. earlandi by the greater number of chambers, an oval-shaped aperture with a double-folded tongue, and a large globular proloculus.

\author{
Family Cassidulinidae d'Orbigny, 1839a \\ Subfamily Cassidulininae d'Orbigny, 1839a \\ Genus Cassidulinoides Cushman, 1927
}

Cassidulinoides parkerianus (Brady, 1881)

(Fig. 12:24-25)

1881 Cassidulina parkeriana Brady: 59, pl. 54, figs. 11-16. 1932a Cassidulina parkeriana Brady; Heron-Allen \& Earland: 359, pl. 9, figs. 22-25.

1975 Cassidulinoides parkerianus (Brady); Anderson: 86, pl. 7, fig. 20 .

2001 Cassidulinoides parvus (Hussey); Igarashi: 153, pl. 10, fig. 12.

2005 Cassidulinoides parkerianus (Brady); Majewski: 204, fig. 23(1-2).

2009 Cassidulinoides parkerianus (Brady); Majewski \& Anderson: 139, fig. 4.

2013 Cassidulinoides parkerianus (Brady); Rodrigues et al.: 214, fig. 3 (4).

Material. Overall, 713 specimens from 32 samples.

Description. Crozier-shaped test, initially planispiral, rapidly uncoiling to become biserial; number of chambers in biserial section quite variable; biserial section cylindrical, straight or arcuate. Chambers subglobose, inflated, with small overlap at the periphery; sutures slightly depressed. Thick, calcareous, perforate, hyaline bi-multilamellar wall. Interiomarginal, loop-shaped aperture; subterminal.

Occurrence. Originally described from the South $\mathrm{Pa}$ cific (Brady, 1881) and subsequently described from various locations around Antarctica (Heron-Allen and Earland, 1932a; Anderson, 1975; Igarashi et al., 2001; Majewski, 2005; Majewski and Anderson, 2009; Rodrigues et al., 2013).

Cassidulinoides porrectus (Heron-Allen and Earland, 1932a)

(Fig. 13:1-2)

1932a Cassidulina crassa d'Orbigny var. porrecta HeronAllen \& Earland, p. 358, pl. 9, figs. 34-37.

1981 Cassidulinoides porrecta (Heron-Allen \& Earland); Milam \& Anderson: 308, pl. 6, fig. 6.

1996 Cassidulinoides porrectus (Heron-Allen \& Earland): Violanti: 65, pl. 9, figs. 2-3. 

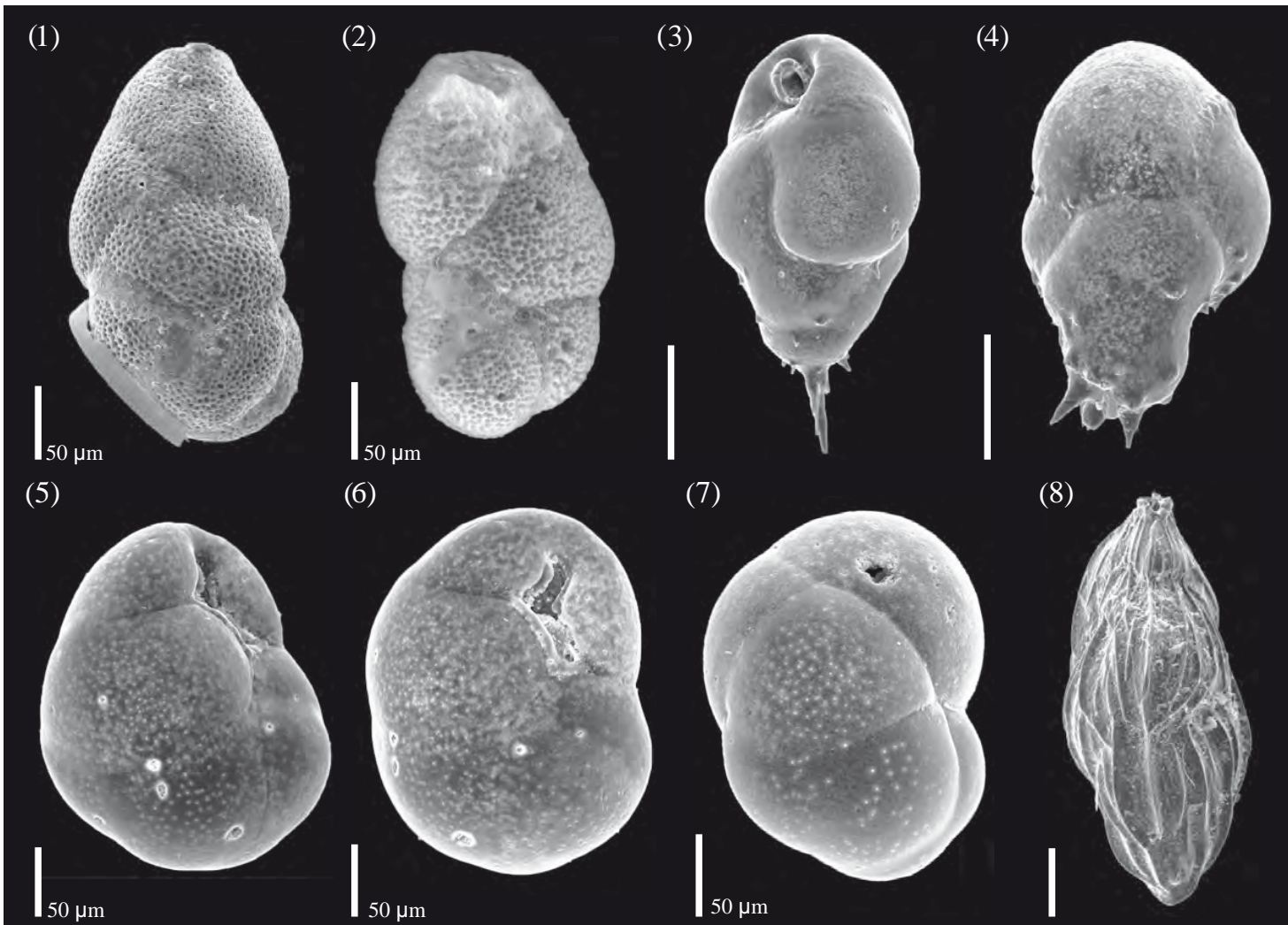

(9)

(10)

(11)

(12)
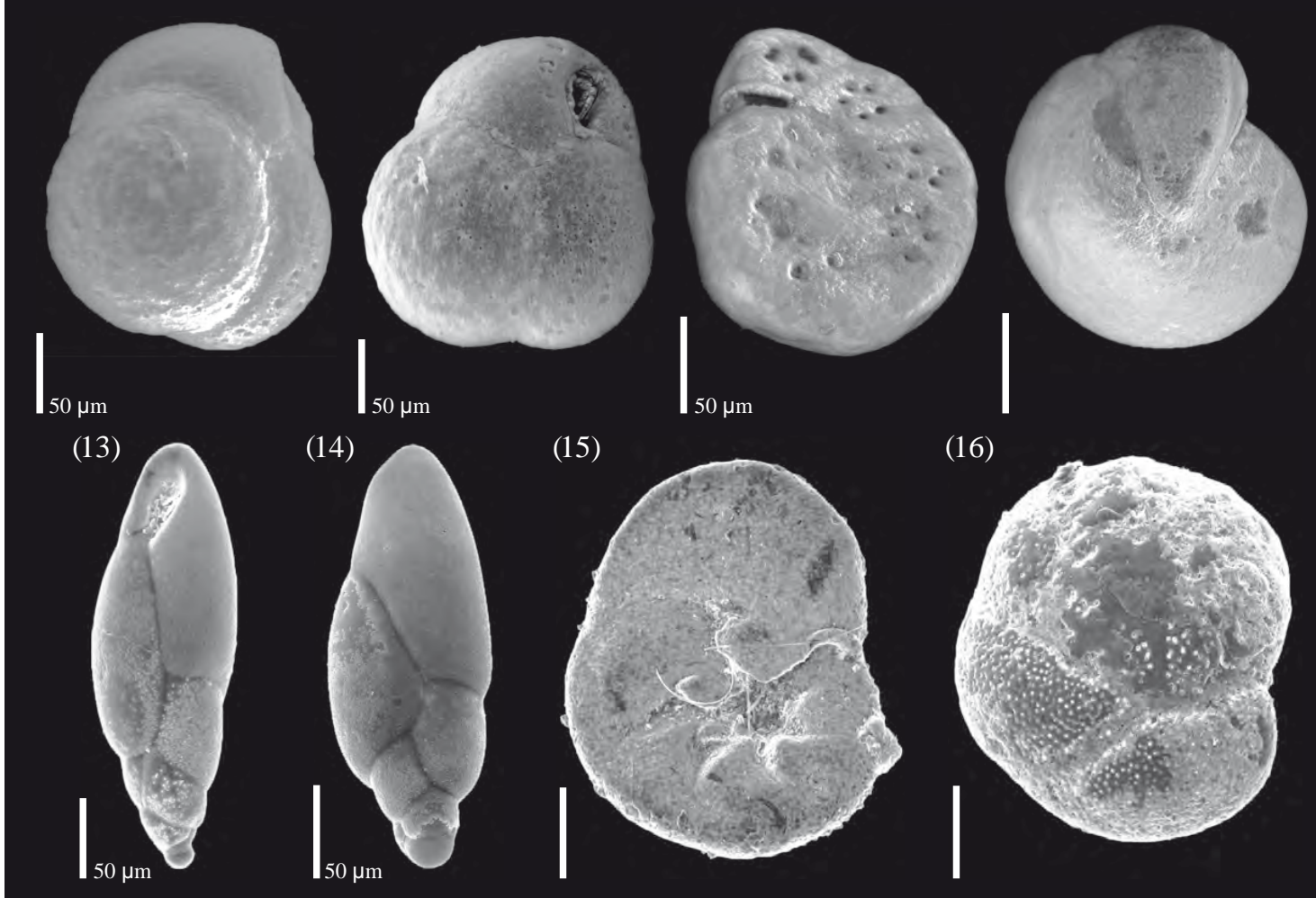

Figure 13. (1-2) Cassidulinoides porrectus (Heron-Allen and Earland) (GC666_002). (3-4) Bulimina aculeata d'Orbigny (GC666_002). (57) Globocassidulina crassa (d'Orbigny) subsp. rossensis Kennett (GC666_002). (8) Trifarina earlandi (Parr (GC666_002)). (9-10) Bulimina sp. 1 (GC666_119). (11-12) Cibicides sp. 1 (BC737; BC738 (D) 0-1 cm). (13-14) Fursenkoina fusiformis (Cushman) (GC666_002). (1516) Discorbis vilardeboanus (d'Orbigny) (GC666_002). (14-16) Nonionella bradii (Chapman) (GC666_002). (Scale bar 100 $\mu \mathrm{m}$ unless otherwise indicated.) 
2001 Cassidulinoides porrectus (Heron-Allen \& Earland); Igarashi et al.: 153, pl. 10, fig. 11.

2005 Cassidulinoides porrectus (Heron-Allen \& Earland); Majewski: 204, fig. 23(3).

2013 Cassidulinoides porrectus (Heron-Allen \& Earland); Rodrigues et al.: p. 214, fig. 3 (3).

Material. Overall, 1452 specimens from 37 samples.

Description. Test small, planispirally enrolled in early stages, uncoiling to become biserial; commonly 2-4 chambers in the biserial part but can be as many as 10 . Chambers subglobose, inflated, with small overlap at the periphery; sutures slightly depressed. Thick, calcareous, perforate, hyaline wall, covered in distinctive large pores. Interiomarginal, loop-shaped aperture, subterminal.

Occurrence. Originally described from various subantarctic locations (Heron-Allen and Earland, 1932a), subsequently in numerous additional Antarctic studies (Milam and Anderson, 1981; Violanti, 1996; Igarashi et al., 2001; Majewski, 2005; Rodrigues et al., 2013).

\section{Genus Globocassidulina Voloshinova, 1960}

\section{Globocassidulina crassa (d'Orbigny) subsp. rossensis} Kennett, 1967

(Fig. 13:5-7)

1967 Globocassidulina crassa (d'Orbigny) subsp. rossensis Kennett 134, pl. 11, figs. 4-6.

1981 Globocassidulina crassa rossensis Kennett; Milam \& Anderson: 312, pl. 10, fig. 1.

1993 Globocassidulina rossensis Kennett; Mackensen et al.: 56, pl. 2, figs. 7-8.

1996 Globocassidulina rossensis Kennett; Violanti: p. 65, pl. 9 , fig. 7.

2006 Globocassidulina rossensis Kennett; Hromic et al.: 124, pl. 1, fig. 5 .

Material. Overall, 727 specimens from 32 samples.

Description. Oval to circular, involute, slightly compressed test; rounded, slightly lobulate, planispiral coil of biserial, inflated chambers that gradually increase in size; four to five pairs in the last whorl. Thin, smooth, calcareous wall. Aperture a narrow, interiomarginal slit with an aerial branch that extends perpendicular to the main slit approximately halfway up the apertural face, surrounded by a narrow rim.

Occurrence. Originally described from the Ross Sea (Kennett, 1967); subsequently described from other Antarctic locations (Milam and Anderson, 1981; Mackensen et al., 1993; Violanti, 1996; Hromic et al., 2006).
Remarks. Distinguished from other subspecies of Globocassidulina crassa (d'Orbigny) by an aerial branch that extends from the main part of the aperture.

\section{Subfamily Ehrenbergininae Cushman, 1927 \\ Genus Ehrenbergina Reuss, 1850}

Ehrenbergina glabra Heron-Allen \& Earland, 1922

1922 Ehrenbergina hystrix var. glabra Heron-Allen \& Earland: 140, pl. 5, figs. 1-6.

1981 Ehrenbergina glabra Heron-Allen \& Earland; Milam \& Anderson: 311, pl. 9, fig. 7.

1990 Ehrenbergina glabra Heron-Allen \& Earland; Mackensen et al.: 254, pl. 1, figs. 5-6.

1996 Ehrenbergina glabra Heron-Allen \& Earland; Violanti: 65 , pl. 9 , fig. 9.

2001 Ehrenbergina glabra Heron-Allen \& Earland; Igarashi et al.: 154 , pl. 11, fig. 1 .

2013 Ehrenbergina glabra Heron-Allen \& Earland; Majewski: 182 , fig. $10(13)$.

Material. Two specimens from one sample.

Description. Biserial test, initially enrolled rapidly uncoiling; lenticular in section with a convex dorsal side; flatter ventral side with a median furrow. Chambers are low and broad with considerable overlap at the peripheral midline. Spinose lateral margins; sutures curved, flush. Calcareous, smooth wall. Curved, elongate, slit-like aperture that runs parallel to the peripheral margin, perpendicular to the base of the apertural face.

Occurrence. Recorded from a number of locations around Antarctica (Milam and Anderson, 1981; Mackensen et al., 1990; Violanti, 1996; Igarashi et al., 2001; Majewski, 2013).

Remarks. Heron-Allen and Earland (1922) distinguished this species from E. hystrix Brady by the absence of spines on the early chambers, the more flattened oral face, the more marginal position of the aperture, and the near absence of striations around the aperture.

Family Buliminidae Jones in Griffith and Henfrey, 1875

Genus Bulimina d'Orbigny, 1826

Bulimina aculeata d'Orbigny, 1826

(Fig. 13:3-4)

1826 Bulimina aculeata d'Orbigny: 269 (no type figure). 1990 Bulimina aculeata d'Orbigny; Mackensen et al.: 255, pl. 2, figs. 1-3. 
1993 Bulimina aculeata d'Orbigny; Mackensen et al.: 54, pl. 1, figs. 3-4.

1994 Bulimina aculeata d'Orbigny; Ishman \& Domack: 152, pl. 2, fig. 8 .

2001 Bulimina aculeata d'Orbigny; Igarashi et al.: 154, pl. 11, fig. 4 .

2013 Bulimina aculeata d'Orbigny; Majewski: 181, fig. 9(89).

Material. Fifty-nine specimens from 20 samples.

Description. Elongate, triserial test, strongly tapered towards base. Globular, inflated chambers rapidly increase in size; distinct, depressed sutures. Smooth, finely perforate, calcareous wall. Early chambers ornamented with long, tapering spines that extend dorsally; fragile and often partially or completely broken. Loop-shaped aperture extends up the face of the final chamber from the basal margin; well-developed, elevated rim.

Occurrence. Originally described from the Adriatic (d'Orbigny, 1826) but more recently from various Antarctic localities (Mackensen et al., 1990, 1993; Ishman and Domack, 1994; Igarashi et al., 2001; Majewski, 2013).

Bulimina subteres Brady, 1881

1881 Bulimina subteres Brady: 55, pl. 50, figs. 17-18.

Material. Three specimens from three samples.

Description. Elongate, triserial, ovate test, rounded at the distal end and tapering to a point at the basal end; slightly inflated chambers; depressed sutures; curved, slitlike aperture extending up the face of the terminal chamber.

Occurrence. Originally described from the Recent of Fiji and the Caribbean (Brady, 1881).

\section{Bulimina sp. 1}

(Fig. 13:9-10)

Material. Twenty-four specimens from 11 samples.

Description. Near spherical test, wider than high; only the three chambers of the final whorl visible. Inflated, globular chambers; depressed sutures. Calcareous, smooth, perforate wall; loop-shaped aperture extending from the base up the face of the final chamber, with a raised rim.

Family Uvigerinidae Haeckel, 1894

Subfamily Angulogerininae Galloway, 1933

Genus Trifarina Cushman, 1923

\section{Trifarina earlandi (Parr, 1950)}

(Fig. 13:8)

1950 Angulogerina earlandi Parr: 341, pl. 12, fig. 21.

2001 Angulogerina earlandi Parr; Igarashi et al.: 154, pl. 11, fig. 7.

2005 Angulogerina earlandi Parr; Majewski: 203, fig. 22(89).

2013 Angulogerina earlandi Parr; Majewski: 181, fig. 9(1314).

Material. Overall, 204 specimens from 22 samples.

Description. Elongate, fusiform test, triserial, becoming uniserial; triangular cross section becoming rectilinear with rounded to sub-acute corners. Base rounded; slightly lobulate margins. Numerous inflated chambers ornamented with narrow, high costae that generally do not cross the sutures; in some specimens final chambers lack ornamentation. Terminal, ovate aperture, with internal hemicylindrical tooth plate, produced on a neck with a phialine lip.

Occurrence. Recorded from a number of locations around Antarctica (Parr, 1950; Igarashi et al., 2001; Majewski, 2005, 2013).

Remarks. Parr (1950) placed this species within Angulogerina. However, Loeblich and Tappan (1988) define Angulogerina as triserial throughout, whilst this species is triserial, becoming uniserial, diagnostic of Trifarina. The high narrow costae of Trifarina earlandi (Parr) distinguish it from the otherwise similar T. angulosa (Williamson).

Family Fursenkoinidae Loeblich \& Tappan, 1961

Genus Fursenkoina Loeblich \& Tappan, 1961

Fursenkoina fusiformis (Cushman, 1930)

(Fig. 13:13-14)

1930 Virgulina fusiformis Cushman: 45, pl. 8, fig. 8.

1981 Fursenkoina fusiformis (Cushman); Milam \& Anderson: 311, pl. 9, fig. 6 .

1994 Fursenkoina fusiformis (Cushman); Ishman \& Domack: 152, pl. 2, fig. 7.

1996 Fursenkoina fusiformis (Cushman); Violanti: 65, pl. 9, figs. 14-15.

2005 Fursenkoina fusiformis (Cushman); Majewski: 204, fig. 23(9-12).

2009 Fursenkoina fusiformis (Cushman); Majewski \& Anderson: 139, fig. 4.

Material. Overall, 1260 specimens from 34 samples.

Description. Narrow, elongate test, ovate in section. High, narrow, slightly inflated chambers, biserial, twisted 
around the test axis. Oblique, depressed sutures; calcareous, hyaline, finely perforate wall, with smooth surface. Narrow, elongate aperture; basal part of the aperture may be closed in adult specimens, leaving an areal comma-shaped opening.

Occurrence. Recorded from a range of Antarctic locations (Milam and Anderson, 1981; Ishman and Domack, 1994; Violanti, 1996; Majewski, 2005; Majewski and Anderson, 2009).

Remarks. Very similar to Stainforthia fusiformis (Williamson), a species common in the high, northern latitudes. F. fusiformis (Cushman) can be distinguished from this species by the shape of the aperture and by being biserial throughout. F. fusiformis (Cushman) is common throughout the high, southern latitudes.

Family Discorbidae Ehrenberg, 1838

Genus Discorbis Lamarck, 1804

Discorbis vilardeboanus (d'Orbigny, 1839b)

(Fig. 13:15-16)

1839b Rosalina vilardeboana d'Orbigny: 44, pl. 6, figs. 13 15.

1932a Discorbis vilardeboana (d'Orbigny); Heron-Allen \& Earland: 409, pl. 13, figs. 37-39.

1975 Rosalina vilardeboana d'Orbigny; Anderson: 88, pl. 8, fig. 10 .

2001 Rosalina globularis d'Orbigny; Igarashi et al.: 154, pl. 11, fig. 13.

2005 Rosalina globularis d'Orbigny; Majewski: 205, fig. 24(1-4).

? 2009 Rosalina Majewski \& Anderson: 139, fig. 4 (14).

2013 Rosalina globularis d'Orbigny; Majewski: 183, fig. 11(1).

Material. Twelve specimens from nine samples.

Description. Trochospiral test; spiral side convex; umbilical side flattened; 2.5 whorls; seven chambers in the final whorl; strongly curved, depressed sutures. Small chamberlets formed in umbilical region below triangular alar projections that protrude from the umbilical margin of each chamber. Thin, calcareous, finely perforate wall. Low, interiomarginal, extra-umbilical, arch-shaped aperture, with a secondary opening at the posterior margin of the umbilical flap.

Occurrence. Originally described from the Falkland Islands (d'Orbigny, 1839b), subsequently from various locations on the Antarctic shelf (Heron-Allen and Earland, 1932a; Anderson, 1975; Igarashi et al., 2001; Majewski, 2005, 2013; Majewski and Anderson, 2009).
Remarks. Chambers less inflated and alar projections more angular than those of Rosalina globularis d'Orbigny, with which it may sometimes be confused.

Family Cibicididae Cushman, 1927

Subfamily Cibicidinae Cushman, 1927

Genus Cibicides de Montfort, 1808

Cibicides sp. 1

(Fig. 13:11-12)

Material. Four specimens from four samples.

Description. Trochospiral, planoconvex test; flat, slightly involute spiral side with somewhat thickened sutures; strongly convex, completely involute umbilical side. Sutures flush except around final chamber; rounded periphery; calcareous wall, coarsely perforate on spiral side with five large pores in each chamber; pores in earlier chambers filled by lamellar thickening; umbilical side finely perforate; keel and apertural face imperforate. Low, interiomarginal, equatorial aperture extending along the spiral side suture and slightly onto the umbilical side, with a narrow lip.

\section{Cibicides sp. 2}

Material. One specimen from one sample.

Description. Trochospiral, planoconvex test; flat, slightly involute spiral side with somewhat thickened sutures; strongly convex, completely involute umbilical side. Calcareous wall, coarsely perforate on spiral side; umbilical side finely perforate; keel and apertural face imperforate; aperture not preserved.

Family Nonionidae Schultze, 1854

Subfamily Nonioninae Schultze, 1854

Genus Nonionella Cushman, 1926

Nonionella bradii (Chapman, 1916)

(Fig. 14:2-4)

1916 Nonionina scapha (Fichtel \& Moll) var. bradii Chapman: 71 , pl. 5, fig. 42 .

1990 Nonionella bradii (Chapman); Mackensen et al.: 254, pl. 1, fig. 4.

1994 Nonionella bradii (Chapman); Ishman \& Domack: 152 , pl. 2, figs. $10 \& 12$.

1994 Nonionella bradii (Chapman); Jones: 108, pl. 109, fig. 16.

1996 Nonionella bradii (Chapman); Violanti: 67, pl. 10, figs. 8, 13, 17 . 

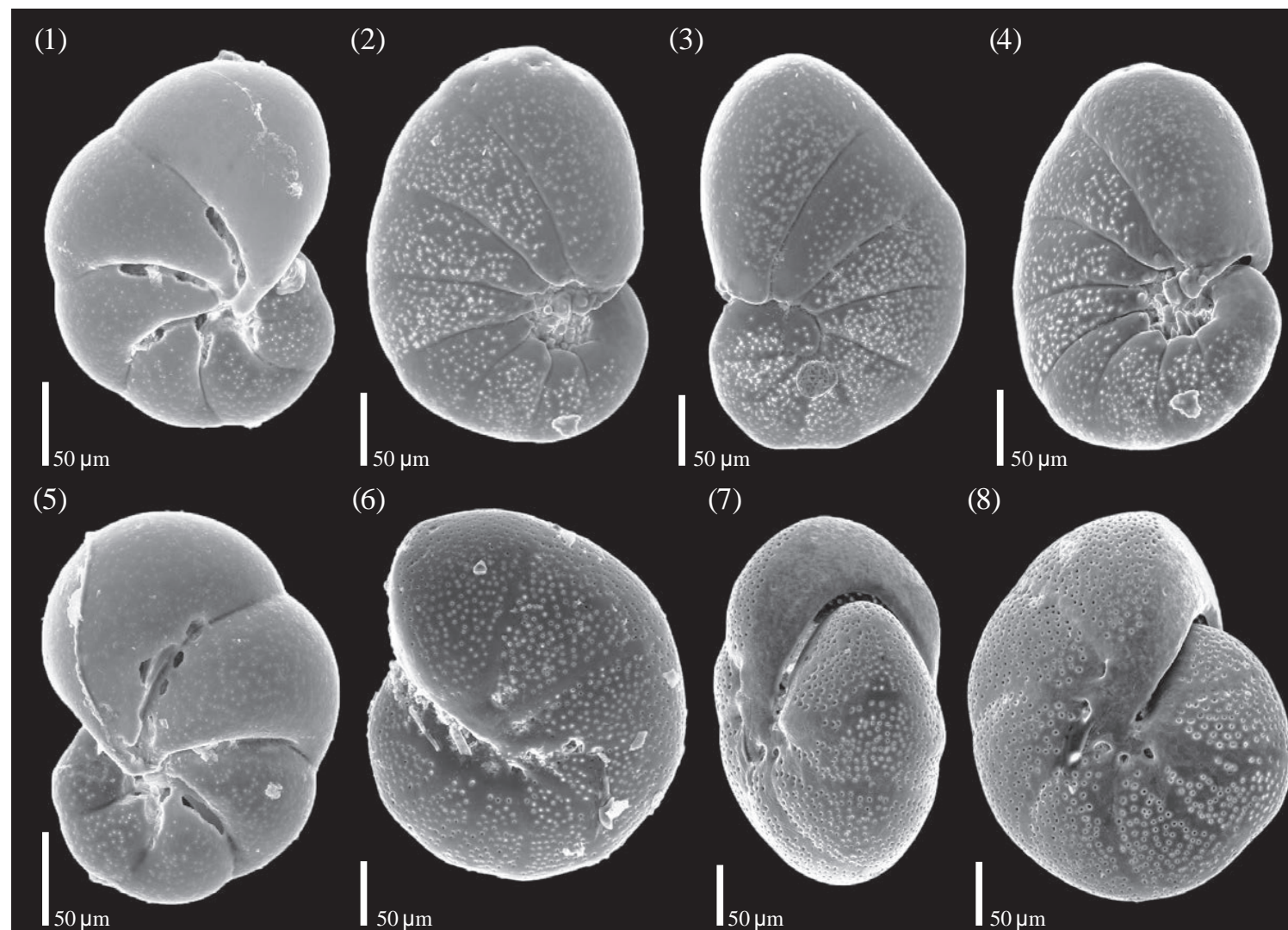

(6)

(7)
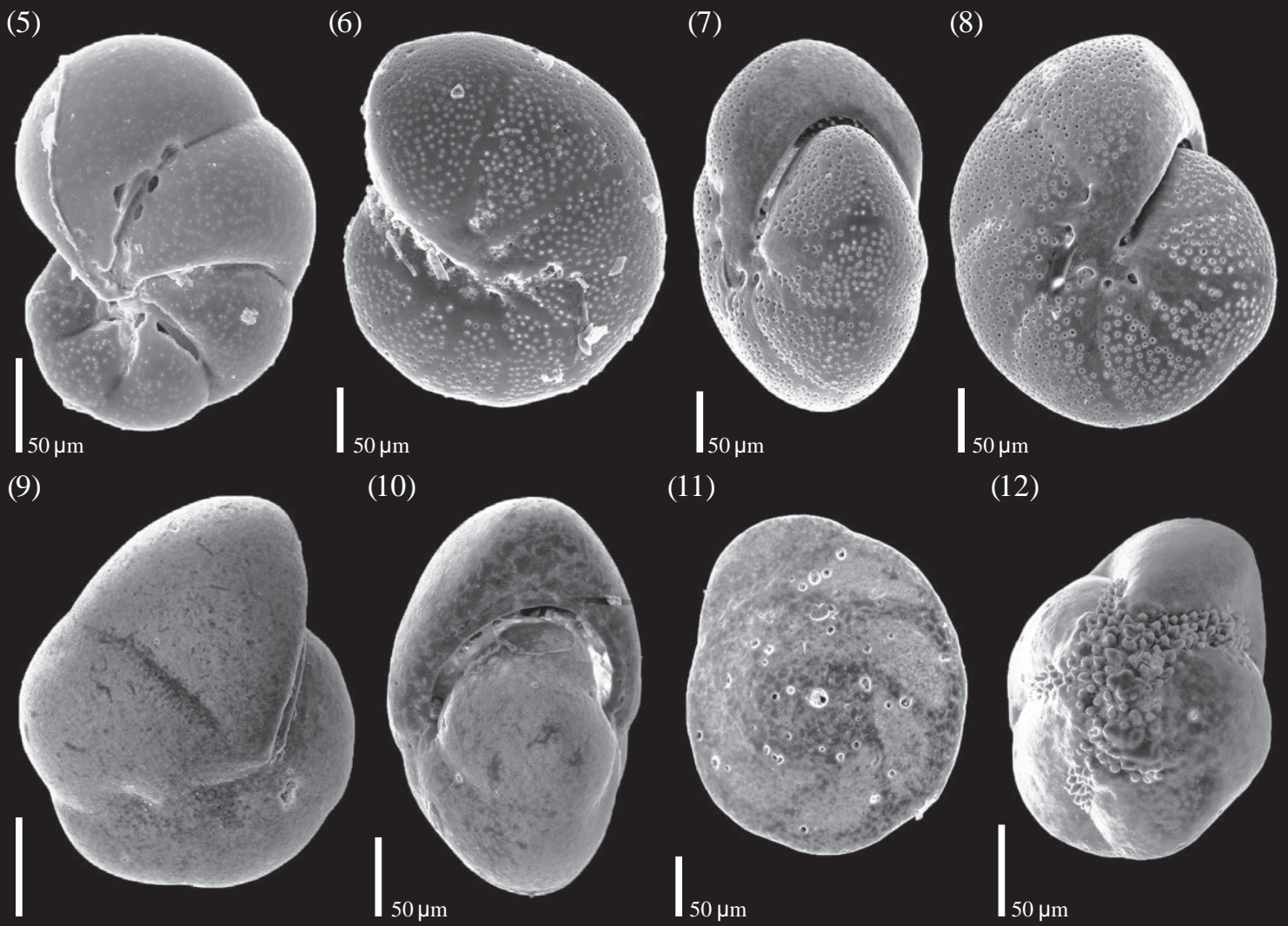

(13)

(14)

(11)

(12)

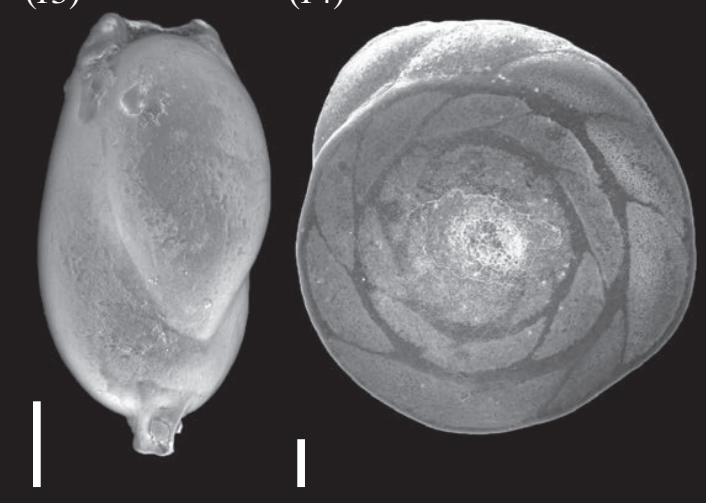

(15)
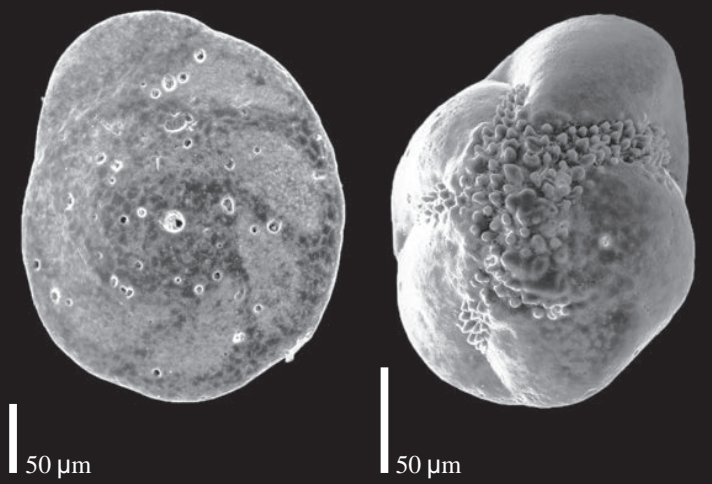

(16)
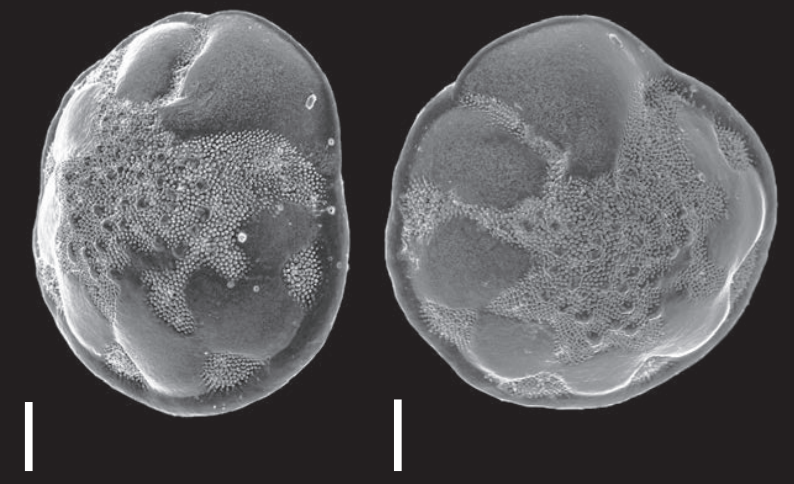

Figure 14. (1 and 5) Nonionella iridea Heron-Allen and Earland (GC666_002). (2-4) Nonionella bradii (Chapman) (GC666_002). (68) Astrononion echolsi Kennett (GC666_002). (9-10) Pullenia subcarinata (d'Orbigny) (GC666_002). (11-12) Buccella sp. 2 (GC666_002). (13) Chilostomella sp. 1 (BC671). (14-16) Buccella sp. 1 (GC666_002). (Scale bar $100 \mu \mathrm{m}$ unless otherwise indicated.) 
2001 Nonionella bradii (Chapman); Igarashi et al.: 155, pl. 12, fig. 5 .

2005 Nonionella bradii (Chapman); Majewski: 206, fig. 25(4-5).

2009 Nonionella bradii (Chapman); Majewski \& Anderson: 139, fig. 4.

Material. Sixty-seven specimens from 17 samples.

Description. Low trochospiral, compressed test with rounded periphery; involute umbilical side; partially evolute spiral side. Low, broad chambers that widen towards the periphery; 9-10 in the final whorl; chambers rapidly enlarge in the final whorl to produce a flared test. Flap-like projections from each chamber overhang the umbilicus. Slightly curved, narrow, depressed sutures. Calcareous, hyaline, finely perforate wall with a smooth surface. Aperture a low arch, interiomarginal, equatorial.

Occurrence. First described from the Ross Sea (Chapman, 1916); subsequently reported from numerous other Antarctic localities (Mackensen et al., 1990; Ishman and Domack, 1994; Jones, 1994; Violanti, 1996; Igarashi et al., 2001; Majewski, 2005; Majewski and Anderson, 2009).

Nonionella iridea Heron-Allen \& Earland, 1932a

(Fig. 14:1 and 5)

1932a Nonionella iridea Heron-Allen \& Earland: 438, pl. 16, figs. 14-16.

1990 Nonionella iridea Heron-Allen \& Earland; Mackensen et al.: 254, pl. 1, figs. 7-9.

1994 Nonionella iridea Heron-Allen \& Earland; Ishman \& Domack: 152, pl. 2, fig. 11.

1996 Nonionella iridea Heron-Allen \& Earland; Violanti: 67, pl. 10, figs. 9, 14, 18.

2001 Nonionella iridea Heron-Allen \& Earland; Igarashi et al.: 155 , pl. 12, fig. 6 .

2005 Nonionella iridea Heron-Allen \& Earland; Majewski: 206, fig. 25(2-3).

2009 Nonionella iridea Heron-Allen \& Earland; Majewski \& Anderson: 139, fig. 4.

2013 Nonionella iridea Heron-Allen \& Earland; Majewski: 182, fig. 10(8).

Material. Overall, 323 specimens from 28 samples.

Description. Low trochospiral, compressed test, with rounded periphery; involute umbilical side; partially evolute spiral side. Low, broad, somewhat inflated chambers that widen towards the periphery; six to seven in the final whorl. Chambers enlarge in the final whorl to produce a slightly flared test; flap-like projections from each chamber overhang the umbilicus and overlap each other. Slightly curved, narrow, depressed sutures. Calcareous, hyaline, finely perforate wall with a smooth surface. Aperture a low arch; interiomarginal, equatorial, supplementary apertures develop in later chambers along the sutures from the umbilicus approximately halfway to the periphery (not visible in all specimens).

Occurrence. Originally described from the subantarctic, in particular South Georgia and the Falkland Islands (Heron-Allen and Earland, 1932a); subsequently reported from locations around Antarctica (Mackensen et al., 1990; Ishman and Domack, 1994; Violanti, 1996; Igarashi et al., 2001; Majewski, 2005, 2013; Majewski and Anderson, 2009).

\section{Subfamily Astrononioninae Saidova, 1981}

Genus Astrononion Cushman and Edwards, 1937

\section{Astrononion echolsi Kennett, 1967}

(Fig. 14:6-8)

1967 Astrononion echolsi Kennett: 134, pl. 11, figs. 7-8. 1981 Astrononion echolsi Kennett; Milam \& Anderson: 313, pl. 11 , fig. 3 .

1994 Astrononion echolsi Kennett; Ishman \& Domack: 152, pl. 2 , fig. 3.

1996 Astrononion echolsi Kennett; Violanti: 67, pl. 10, fig. 16.

2001 Astrononion echolsi Kennett; Igarashi et al.: 155, pl. 12, fig. 11.

2005 Astrononion echolsi Kennett; Majewski: 206, fig. 25(67).

2009 Astrononion echolsi Kennett; Majewski \& Anderson: 139, fig. 4

2013 Astrononion echolsi Kennett; Majewski: 182, fig. 10(7).

Material. Overall, 1216 specimens from 39 samples.

Description. Involute, planispiral, slightly compressed test, with a rounded periphery. Size of chambers gently increases as they are added; eight to nine in the final whorl; somewhat inflated in some specimens but more commonly not. Slightly limbate, curved sutures; slightly depressed to flush. Indistinct, tube-like supplementary chambers extend from the umbilical region, only visible as sunken pits on the sutural lines. Calcareous, hyaline, finely perforate, smooth wall, often with slightly yellow colour. Primary aperture a low, interiomarginal, equatorial arch.

Occurrence. Abundant in the Ross Sea and Scotia Sea, where it was first described (Kennett, 1967); also recorded from various other Antarctic locations (Milam and Anderson, 1981; Ishman and Domack, 1994; Violanti, 1996; Igarashi et al., 2001; Majewski, 2005, 2013; Majewski and Anderson, 2009). 
Subfamily Pulleniinae Schwager, 1877

Genus Pullenia Parker \& Jones in Carpenter et al., 1862

Pullenia subcarinata (d'Orbigny, 1839b)

(Fig. 14:9-10)

1839b Nonionina subcarinata d'Orbigny: 28, pl. 5, figs. 2324.

1932a Pullenia subcarinata (d'Orbigny); Heron-Allen \& Earland: 403, pl. 13, figs. 14-18.

1981 Pullenia subcarinata (d'Orbigny); Milam \& Anderson: 313, pl. 11, fig. 5.

1993 Pullenia subcarinata (d'Orbigny); Mackensen et al.: 58, pl. 3, figs. 8-9.

? 1994 Pullenia quinqueloba (Reuss); Jones: 92, pl. 84, figs. 14-15.

1996 Pullenia subcarinata (d'Orbigny); Violanti: 48, pl. 10, fig. 19.

Material. Thirty-nine specimens from 18 samples.

Description. Involute, planispiral, slightly compressed test with a rounded periphery. Chambers slightly inflated, giving the test a slightly lobulate outline; five to six in the final whorl; face of final chamber has a somewhat triangular shape. Near-radial, slightly depressed sutures. Calcareous, smooth, very finely perforate wall. Aperture a low, interiomarginal, equatorial, crescentic slit, bordered on the upper margin by a raised lip.

Occurrence. Originally described from recent deposits from the Falkland Islands (d'Orbigny, 1839b); subsequently recorded from around Antarctica (Heron-Allen and Earland, 1932a; Milam and Anderson, 1981; Mackensen et al., 1993; Jones, 1994; Violanti, 1996).

Remarks. Pullenia quinqueloba (Reuss) is morphologically very similar to $P$. subcarinata (d'Orbigny), and Jones (1994) assigns the Challenger specimens to P. quinqueloba (Reuss). However, Pullenia quinqueloba (Reuss) was originally described from German Eocene deposits, and we therefore assign our specimens to $P$. subcarinata (d'Orbigny), which was originally described from Recent deposits from the Falkland Islands.

Family Chilostomellidae Brady, 1881

Subfamily Chilostomellinae Brady, 1881

Genus Chilostomella Reuss, 1849

\section{Chilostomella sp. 1}

(Fig. 14:13)

Material. One specimen from one sample.
Description. Ovoid, planispiral, involute test; nearcircular cross section. Two strongly embracing, inflated chambers in final whorls; final chamber significantly larger. Calcareous, finely perforate wall; smooth surface; equatorial, interiomarginal, narrow slit-shaped aperture, with a raised margin. Distinctive spine-like structure on basal end.

Family Trichohyalidae Saidova, 1981

Genus Buccella Andersen, 1952

\section{Buccella sp. 1}

(Fig. 14:14-16)

Material. Overall, 241 specimens from 31 samples.

Description. Large, biconvex, carinate, trochospiral test; spiral side low convex and evolute; umbilical side higher and involute. Numerous rhomboidal chambers with curved sides, slightly inflated on the umbilical side; three and a half whorls; 8-10 chambers in the final whorl. Sutures on spiral side flush, slightly limbate, swept back towards periphery, straighter and depressed on the umbilical side. Umbilical region and sutural fissures on umbilical side filled with a mixture of fine and coarse granules; spiral side surface smooth, finely perforate on the chamber faces; periphery very slightly lobate, with a distinct keel. Aperture not visible in any of the specimens examined; may be covered by the abundant granules.

Remarks. Openings at the end of the sutural fissures that are common in members of this genus are not visible in any of the specimens examined here.

\section{Buccella sp. 2}

(Fig. 14:11-12)

Material. Twenty-five specimens from 12 samples.

Description. Test small for this genus; trochospiral, biconvex; spiral side flatter and evolute; umbilical side convex and involute. Chambers almost semi-circular; two whorls; six to seven chambers in the final whorl; sutures limbate, flush, slightly curved on the spiral side, very depressed on the umbilical side. Umbilical region and sutural fissures on umbilical side filled with granules; spiral side surface smooth, finely perforate on the chamber faces; periphery slightly lobate and thickened but not carinate. Aperture not visible in any of the specimens examined and may be covered by the abundant granules.

Remarks. Bears some similarity to Epistominella exigua (Brady), especially in light microscope. 
Genus Neogloboquadrina Bandy, Frerichs \& Vincent, 1967

\section{Neogloboquadrina pachyderma (Ehrenberg, 1861)}

1861 Aristerospira pachyderma Ehrenberg: 276, 277, 303. 1932a Globigerina pachyderma Ehrenberg; Heron-Allen \& Earland: 401, pl. 13, figs. 9-13.

1975 Globigerina pachyderma Ehrenberg; Anderson: 90, pl. 9 , fig. 4.

1996 Neogloboquadrina pachyderma (Ehrenberg); Violanti: 62, pl. 8, figs. 17 and 21.

2001 Neogloboquadrina pachyderma (Ehrenberg); Igarashi et al.: 152, pl. 10, figs. 8-9.

Material. Overall, 209 specimens from 27 samples.

Description. Globular, low trochospiral test; globular chambers that rapidly enlarge as added; five to six in the final whorl. Straight to slightly curved, depressed, radial sutures; rounded periphery; open umbilical region. Calcareous, perforate wall; interiomarginal, extra-umbilical to umbilical aperture with bordering lip (may be absent in later stages).

Data availability. All the data analysed in this paper are available in the tables provided within the paper or in the Supplement.

\section{The Supplement related to this article is available online at https://doi.org/10.5194/jm-37-25-2018-supplement.}

Competing interests. The authors declare that they have no conflict of interest.

Acknowledgements. This study forms part of a doctoral project carried out by Rowan Dejardin, funded by the Centre for Environmental Geochemistry (University of Nottingham and the British Geological Survey) and supported by BGS-University Funding Initiative (BUFI). We thank the officers, crew, and scientific party on board the RRS James Clark Ross during scientific cruises JR257 and JC15002. Participation in cruise JR15002 by Rowan Dejardin was funded by the British Antarctic Survey Collaborative Gearing Scheme. We thank Hilary Sloane and Jack Lacey (BGS) for analytical assistance and Tony Milodowski and Gren Turner for their assistance generating the SEM images. We also thank the editor, Laia Alegret, one anonymous reviewer, and Wojciech Majewski for their insightful comments, which helped to strengthen this paper. This project was supported by NERC Isotope Geoscience Facility grant IP/1495/1114 (RCUK).

Edited by: Laia Alegret

Reviewed by: Wojciech Majewski and one anonymous referee

\section{References}

Alekseychik-Mitskevich, L. S.: Towards the classification of the foraminiferal family Haplophragmiidae, Trudy Vsesoyuzznogo neftyanogo Nauchnoissledovatel'skogo Geologorazvedochnogo Instituta, 343, 12-44, 1973.

Andersen, H. V.: Buccella, a new genus of the rotalid foraminifera, Journal of the Washington Academy of Sciences, 42, 143-151, 1952.

Anderson, J. B.: Ecology and distribution of foraminifera in the Weddell Sea of Antarctica, Micropalaeontology, 21, 69-96, 1975.

Bailey, J. W.: Microscopical examination of soundings made by the U.S. Coast Survey of the Atlantic coast of the U.S., Smithsonian Contributions, 2, 1-48, 1851.

Bandy, O. L., Frerichs, W. E., and Vincent, E.: Origin, development, and geologic significance of Neogloboquadrina Bandy, Frerichs, and Vincent, gen. nov., Contributions from the Cushman Foundation for Foraminiferal Research, 18, 152-157, 1967.

Barker, R. W.: Taxonomic notes on the species figured by H.B. Brady in his report of the foraminifera dredged by HMS Challenger during the years 1873-1876, American Association of Petroleum Geologists Special Publication, 9, 10238, 2-240, 1960.

Bernhard, J. M.: Distinguishing live from dead foraminifera: Methods review and proper applications, Micropaleontology, 46, 3846, 2000.

Brady, H. B.: Contributions to the knowledge of the foraminifera. - On the rhizopodal fauna of the Shetlands, Transactions of the Linnaean Society, 24, 463-476, https://doi.org/10.1111/j.10963642.1863.tb00170.x, 1864.

Brady, H. B.: Notes on some of the Reticularian Rhizopoda of the "Challenger" Expedition. I. On new or little known arenaceous types, Q. J. Microsc. Sci., 19, 20-62, 1879.

Brady, H. B.: Notes on some of the Reticularian Rhizopoda of the "Challenger" Expedition. Part III, Q. J. Microsc. Sci., 21, 31-71, 1881.

Brady, H. B.: Report on the scientific results of the voyage of H.M.S. Challenger during the years 1873-76, in: Zoology of the Challenger Expedition, edited by: Thompson, C. W. and Murray, J., London, Neill, Edinburgh, 1884.

Brandon, M. A., Murphy, E. J., Whitehouse, M. J., Trathan, P. N., Murray, A. W. A., Bone, D. G., and Priddle, J.: The shelf break front to the east of the sub-Antarctic island of South Georgia, Cont. Shelf Res., 19, 799-819, https://doi.org/10.1016/s02784343(98)00112-5, 1999.

Brandon, M. A., Murphy, E. J., Trathan, P. N., and Bone, D. G.: Physical oceanographic conditions to the northwest of the subAntarctic Island of South Georgia, J. Geophys. Res.-Oceans, 105, 23983-23996, 10.1029/2000jc900098, 2000.

Brönnimann, P.: Two new genera of Recent Trochamminidae (Foraminiferida), Achives des Sciences, Geneve, 29, 215-218, 1976.

Brönnimann, P. and Beurlen, G.: Recent benthonic foraminifera from Brasil. Morphology and ecology. Part I, Achives des Sciences, Geneve, 30, 77-89, 1977.

Brönnimann, P. and Whittaker, J. E.: The Trochamminacea of the Discovery Reports, British Museum, London, 1988. 
Brönnimann, P., Zaninetti, L., and Whittaker, J. E.: On the classification of the Trochamminacea (Foraminiferida), J. Foramin. Res., 13, 202-218, 1983.

Caralp, M. H.: Abundance of Bulimina exilis and Melonis barleeanum - relationship to the quality of marine organic-matter, Geo-Marine Letters, 9, 37-43, https://doi.org/10.1007/bf02262816, 1989.

Carpenter, W. B.: On the rhizopodal fauna of the deep sea, Proceedings of the Royal Society of London, 18, 59-62, 1869.

Carpenter, W. B., Parker, W. K., and Jones, T. R.: Introduction to the study of the Foraminifera, Ray Society, London, 1862.

Caulle, C., Mojtahid, M., Gooday, A. J., Jorissen, F. J., and Kitazato, H.: Living (Rose-Bengal-stained) benthic foraminiferal faunas along a strong bottom-water oxygen gradient on the Indian margin (Arabian Sea), Biogeosciences, 12, 5005-5019, https://doi.org/10.5194/bg-12-5005-2015, 2015.

Chapman, F.: Report on the Foraminifera and Ostracoda from elevated deposits on the shores of the Ross Sea, British Antarctic Expedition 1907-9 under the command of Sir E. H. Shackleton, C.V.O.: Reports on the scientific investigations, Geology, Vol. II - Contributions to the palaeontology and petrology of South Victoria Land, edited by: Benson, W. N., Chapman, F., Cohen, F., Cotton, L. A., Hedley, C., Jensen, H. I., Mawson, D., Skeats, E. W., Thomson, J. A., Walkom, A. B., and Woolnough, W. G., William Heinemann, London, 1916.

Chapman, F., Parr, W. J., and Collins, A. C.: Tertiary Foraminifera of Victoria, Australia. The Balcombian deposits of Port Phillip, Journal of the Linnaean Society, 38, 553-576, 1934.

Clark, F. E., Patterson, R. T., and Fishbein, E.: Distribution of Holocene benthic foraminifera from the tropical southwest Pacific Ocean, J. Foramin. Res., 24, 241-267, 1994.

Corliss, B. H. and Emerson, S.: Distribution of Rose-Bengal stained deep-sea benthic foraminifera from the Nova Scotian continental-margin and Gulf of Maine, Deep-Sea Res. Pt. A, 37, 381-400, https://doi.org/10.1016/0198-0149(90)90015-n, 1990.

Cushman, J. A.: A monograph of the Foraminifera of the North Pacific Ocean. Part I. Astrorhizidae and Lituolidae, Bulletin of the United States National Museum, 71, 1-134, 1910.

Cushman, J. A.: A monograph of the foraminifera of the North Pacific Ocean. Pt. III. Lagenidae, Bulletin of the United States National Museum, 71, 1-125, 1913.

Cushman, J. A.: The foraminifera of the Atlantic Ocean, Part 4. Lagenidae, Bulletin United States National Museum, 104, 1-228, 1923.

Cushman, J. A.: Foraminifera of the typical Monerey of California, Cushman Foundation for Foraminiferal Research Special Publication, 2, 53-69, 1926.

Cushman, J. A.: An outline of a re-classification of the foraminifera, Contributions from the Cushman laboratory for foraminiferal research, 3, 1-105, 1927.

Cushman, J. A.: The foraminifera of the Atlantic Ocean, Part 7, Nonionidae, Camerinidae, Peneroplidae and Alveolinellidae, Bulletin United States National Museum, 104, 1-79, 1930.

Cushman, J. A.: Foraminifera, their classification and economic use Cushman Lab. Foram. Res., Special Publications Cushman Laboratory for Foraminiferal Research, 4, 1-349, 1933.

Cushman, J. A.: Foraminifera of the United States Antarctic Service Expedition 1939-1941, Proceedings, American Philosophical Society, 89, 285-288, 1945.
Cushman, J. A. and Edwards, P. G.: Astrononion a new genus of the foraminifera and its species, Contributions from the Cushman laboratory for foraminiferal research, 13, 29-36, 1937.

d'Orbigny, A.: Tableau méthodique de la classe des Céphalopodes, Ann. Sci. Nat., 7, 245-314, 1826.

d'Orbigny, A.: Foraminifères, in: Histoire Physique, Politique et Naturelle de l'île de Cuba, edited by: de la Sagra, R., A. Bertrand, Paris, 1-224, 1839a.

d'Orbigny, A.: Voyage dans l'Amérique Méridionale (le Brésil, la République orientale de l'Uruquay, la République Argentine, la Patagonie, la République du Chili, la République de Bolivia, la République du Pérou) éxécuté pendant les années 1826, 1827, 1832 et 1833 in: Foraminifères, edited by: Levrault, S., Bertrand, Paris, 1-86, 1839b.

Defrance, J. L. M.: Dictionnaire des Sciences Naturelles, F. G. Levrault, Strasbourg, 1824.

DeLaca, T. E.: The morphology and ecology of Astrammina rara, J. Foramin. Res., 16, 216-233, 1986.

Earland, A.: Foraminifera, Part II, South Georgia, London, 27-138, 1933.

Earland, A.: Foraminifera. Part III. The Falklands sector of the Antarctic (excluding South Georgia), London, 1-208, 1934.

Echols, R. J.: Distribution of foraminifera in sediments of the Scotia Sea area, Antarctic waters, in: Antarctic Oceanography I, edited by: Reid, J. L., American Geophysical Union, Washington, D.C., 93-168, 1971.

Ehrenberg, C. G.: Uber die Bildung der Kreidefelsen und des Kreidemergels durch unsichtbare Organismen, Physikalische Abhandlungen der Koniglichen Akademie der Wissenschaften zu Berlin, 1838, 59-147, 1838.

Ehrenberg, C. G.: Elemente des tiefen Meeresgrundes im Mexikanishen Golfstrome bei Florida: uber die Tiefgrund-Verhaltnisse des Oceans am eingange der Davisstrasse und bei Island, Monatsbericht der Koniglichen Preussichen Akademie der Wissenschaften zu Berlin, 1861, 275-315, 1861.

Elderfield, H., Yu, J., Anand, P., Kiefer, T., and Nyland, B.: Calibrations for benthic foraminiferal $\mathrm{Mg} / \mathrm{Ca}$ paleothermometry and the carbonate ion hypothesis, Earth Planet. Sc. Lett., 250, 633649, https://doi.org/10.1016/j.eps1.2006.07.041, 2006.

Elderfield, H., Greaves, M., Barker, S., Hall, I. R., Tripati, A., Ferretti, P., Crowhurst, S., Booth, L., and Daunt, C.: A record of bottom water temperature and seawater $\delta^{18} \mathrm{O}$ for the Southern Ocean over the past $440 \mathrm{kyr}$ based on $\mathrm{Mg} / \mathrm{Ca}$ of benthic foraminiferal Uvigerina spp, Quaternary Sci. Rev., 29, 160-169, https://doi.org/10.1016/j.quascirev.2009.07.013, 2010.

Elderfield, H., Ferretti, P., Greaves, M., Crowhurst, S., McCave, I. N., Hodell, D., and Piotrowski, A. M.: Evolution of Ocean Temperature and Ice Volume Through the Mid-Pleistocene Climate Transition, Science, 337, 704-709, https://doi.org/10.1126/science.1221294, 2012.

Enge, A. J., Nomaki, H., Ogawa, N. O., Witte, U., Moeseneder, M. M., Lavik, G., Ohkouchi, N., Kitazato, H., Kucera, M., and Heinz, P.: Response of the benthic foraminiferal community to a simulated short-term phytodetritus pulse in the abyssal North Pacific, Mar. Ecol.-Prog. Ser., 438, 129-142, https://doi.org/10.3354/meps09298, 2011.

Fontanier, C., Jorissen, F. J., Chaillou, G., David, C., Anschutz, P., and Lafon, V.: Seasonal and interannual variability of benthic foraminiferal faunas at $550 \mathrm{~m}$ depth in the Bay of Biscay, 
Deep-Sea Res. Pt. I, 50, 457-494, https://doi.org/10.1016/s09670637(02)00167-x, 2003.

Fontanier, C., Jorissen, F., Anschutz, P., and Chaillou, G.: Seasonal variability of benthic foraminiferal faunas at $1000 \mathrm{~m}$ depth in the Bay of Biscay, J. Foramin. Res., 36, 61-76, https://doi.org/10.2113/36.1.61, 2006a.

Fontanier, C., Mackensen, A., Jorissen, F. J., Anschutz, P., Licari, L., and Griveaud, C.: Stable oxygen and carbon isotopes of live benthic foraminifera from the Bay of Biscay: Microhabitat impact and seasonal variability, Mar. Micropaleontol., 58, 159-183, https://doi.org/10.1016/j.marmicro.2005.09.004, 2006b.

Fontanier, C., Jorissen, F. J., Michel, E., Cortijo, E., Vidal, L., and Anschutz, P.: Stable oxygen and carbon isotopes of live (stained) benthic foraminifera from Cap-Ferret Canyon (Bay of Biscay), J. Foramin. Res., 38, 39-51, https://doi.org/10.2113/gsjfr.38.1.39, 2008.

Fontanier, C., Garnier, E., Brandily, C., Dennielou, B., Bichon, S., Gayet, N., Eugene, T., Rovere, M., Grémare, A., and Deflandre, B.: Living (stained) benthic foraminifera from the Mozambique Channel (eastern Africa): Exploring ecology of deepsea unicellular meiofauna, Deep-Sea Res. Pt. I, 115, 159-174, https://doi.org/10.1016/j.dsr.2016.06.007, 2016.

Frerichs, W. E.: Recent arenaceous foraminifers from Gulf of Mexico, Palaeontological Contributions, University of Kansas, 46, 12, 1969.

Galloway, J. J.: A manual of Foraminifera, Principia Press, Bloomington, 1933

Gaździcki, A. and Majewski, W.: Recent foraminifera from Goulden Cove of King George Island, Antarctica, Pol. Polar Res., 24, 3-12, 2003.

Gehlen, M., Mucci, A., and Boudreau, B.: Modelling the distribution of stable carbon isotopes in porewaters of deepsea sediments, Geochim. Cosmochim. Ac., 63, 2763-2773, https://doi.org/10.1016/s0016-7037(99)00214-8, 1999.

Geslin, E., Heinz, P., Jorissen, F., and Hemleben, C.: Migratory responses of deep-sea benthic foraminifera to variable oxygen conditions: laboratory investigations, Mar. Micropaleontol., 53, 227-243, https://doi.org/10.1016/j.marmicro.2004.05.010, 2004.

Glaessner, M. F.: Die Entfaltung der Foraminiferenfamilie Buliminidae, Problemy Palaeontologii, Palaeontologicheskaya Laboratoriya Moskovskogo Gosudarstvennogo Universiteta, 2-3, 411422, 1937.

Goes, A.: A synopsis of the Arctic and Scandinavian Recent marine Foraminifera hitherto discovered, Kongl. svenka vetenskapsAkademiens handlinger 25, 1-127, 1894.

Gooday, A. J.: A response by benthic foraminifera to the deposition of phytodetritus in the deep-sea, Nature, 332, 70-73, https://doi.org/10.1038/332070a0, 1988.

Gooday, A. J. and Hughes, J. A.: Foraminifera associated with phytodetritus deposits at a bathyal site in the northern Rockall Trough (NE Atlantic): seasonal contrasts and a comparison of stained and dead assemblages, Mar. Micropaleontol., 46, 83110, https://doi.org/10.1016/s0377-8398(02)00050-6, 2002.

Gooday, A. J., da Silva, A. A., Koho, K. A., Lecroq, B., and Pearce, R. B.: The "mica sandwich"; a remarkable new genus of Foraminifera (Protista, Rhizaria) from the Nazare Canyon (Portuguese margin, NE Atlantic), Micropaleontology, 56, 345-357, 2010.
Griffith, J. W. and Henfrey, A.: The Micrographic Dictionary, van Voorst, London, 1875.

Gross, O.: Influence of temperature, oxygen and food availability on the migrational activity of bathyal benthic foraminifera: evidence by microcosm experiments, Hydrobiologia, 426, 123-137, https://doi.org/10.1023/a:1003930831220, 2000.

Haeckel, E.: Systematische Phylogenie. Entwurf eines Naturlichen Systems der Organismen auf Grund ihrer Stammesgeschichte. Theil 1, Systematische Phylogenie der Protisten und Pflanzen, Georg Reimer, Berlin, 1894

Hayward, B. W., Kawagata, S., Sabaa, A. T., Grenfell, H. R., van Kerckhoven, L., Johnson, K., and Thomas, E.: The last global extinction (Mid-Pleistocene) of deep-sea benthic foraminifera (Chrysalogoniidae, Ellipsoidinidae, Glandulonodosariidae, Plectofrondiculariidae, Pleursostomellidae, Stilostomellidae), their Late Cretaceous-Cenozoic history and taxonomy, Cushman Foundation for Foraminiferal Research Special Publication, 43, 1-410, 2012.

Heron-Allen, E. and Earland, A.: On some Foraminifera from the North Sea, etc., dredged by the Fisheries Cruiser "Goldseeker" (International North Sea Investigations - Scotland). I. On some new Astrorhizidae and their shell-structure, Journal of the Royal Microscopical Society, 1912, 382-389, 1912.

Heron-Allen, E. and Earland, A.: Les Foraminifères des "Sables Rouges" du golfe de Ajaccio (Côte Nord), Bulletin de la Société des sciences historiques et naturelles de la Corse, 42, 109-149, 1922.

Heron-Allen, E. and Earland, A.: XXVII. - Some new Foraminifera from the South Atlantic, Journal of the Royal Microscopical Society, 49, 324-334, https://doi.org/10.1111/j.13652818.1929.tb00787.x, 1929.

Heron-Allen, E. and Earland, A.: Some new foraminifera from the South Atlantic, Part 3., Journal of the Royal Microscopical Society, 50, 38-45, 1930.

Heron-Allen, E. and Earland, A.: Foraminifera. Part 1. The ice-free area of the Falkland Islands and adjacent seas, Cambridge University Press, London, 291-460, 1932a.

Heron-Allen, E. and Earland, A.: Some new foraminifera from the South Atlantic, IV, Journal of the Royal Microscopical Society, 52, 253-261, 1932b.

Herb, R.: Distribution of Recent Benthonic Foraminifera in the Drake Passage, in: Biology of the Antarctic Seas IV, American Geophysical Union, 251-300, 1971.

Hermelin, J. O. R.: Pliocene benthic foraminifera from the OntongJava plateau (western equatorial Pacific Ocean): faunal response to changing paleoenvironments, Cushman Foundation for Foraminiferal Research Special Publication, 26, 1-143, 1989.

Hogg, O. T., Barnes, D. K. A., and Griffiths, H. J.: Highly Diverse, Poorly Studied and Uniquely Threatened by Climate Change: An Assessment of Marine Biodiversity on South Georgia's Continental Shelf, Plos One, 6, e19795, https://doi.org/10.1371/journal.pone.0019795, 2011.

Höglund, H.: Foraminifera in the Gullmar Fjord and the Skagerak, Zoologiska Bidrag fran Uuppsala, 26, 1-328, 1947.

Holsten, J., Stott, L., and Berelson, W.: Reconstructing benthic carbon oxidation rates using $\delta 13 \mathrm{C}$ of benthic foraminifers, Mar. Micropaleontol., 53, 117-132, https://doi.org/10.1016/j.marmicro.2004.05.006, 2004. 
Hoogakker, B. A. A., Elderfield, H., Schmiedl, G., McCave, I. N., and Rickaby, R. E. M.: Glacial-interglacial changes in bottomwater oxygen content on the Portuguese margin, Nat. Geosci., 8, 40-43, https://doi.org/10.1038/ngeo2317, 2015.

Hromic, T., Ishman, S., and Silva, N.: Benthic foraminiferal distributions in Chilean fjords: $47^{\circ} \mathrm{S}$ to $54^{\circ} \mathrm{S}$, Mar. Micropaleontol., 59, 115-134, https://doi.org/10.1016/j.marmicro.2006.02.001, 2006.

Igarashi, A., Numanami, H., Tsuchiya, Y., and Fukucki, M.: Bathymetric distribution of fossil foraminifera within marine sediment cores from the eastern part of Lutzow-Holm Bay, East Antarctica, and its paleoceanographic implications, Mar. Micropaleontol., 42, 125-162, https://doi.org/10.1016/s03778398(01)00004-4, 2001

Ishman, S. E. and Domack, E. W.: Oceanographic controls on benthic foraminifers from the Bellingshausen margin of the Antarctic Peninsula, Mar. Micropaleontol., 24, 119-155, https://doi.org/10.1016/0377-8398(94)90019-1, 1994.

Jones, A. F.: The Micrographic Dictionary, edited by: Griffith, J. W. and Henfrey, A., van Voorst, London, 1875.

Jones, R. W.: A revised classification of the unilocular Nodosariida and Buliminida (Foraminifera), Revista Espanola de Micropaleontologia, 16, 91-160, 1984.

Jones, R. W.: The Challenger Foraminifera, Oxford University Press, Oxford, 1994.

Jorissen, F. J., deStigter, H. C., and Widmark, J. G. V.: A conceptual model explaining benthic foraminiferal microhabitats, Mar. Micropaleontol., 26, 3-15, https://doi.org/10.1016/03778398(95)00047-x, 1995.

Jorissen, F. J., Fontanier, C., and Thomas, E.: Paleoceanographical Proxies Based on Deep-Sea Benthic Foraminiferal Assemblage Characteristics, in: Proxies in Late Cenozoic Paleoceanography, edited by: Hillaire-Marcel, C., and de Vernal, A., Developments in Marine Geology, Elsevier, Amsterdam, 263-325, 2007.

Kaminski, M. A.: The Year 2000 Classification of the Agglutinated Foraminifera, in: Proceedings of the Sixth International Workshop on Agglutinated Foraminifera (Prague, Czech Republic, 17 September 2001), edited by: Kaminski, M. A. and Bubik, M., Grzybowski Foundation Special Publication, London, UK, 237255, 2004

Kaminski, M. A. and Gradstein, F. M.: Atlas of Paleogene Cosmopolitan deep-water agglutinated foraminifera, Grzybowski Foundation Special Publication, Krakow, 2005.

Kanmacher, F.: Adam's Essays on the Microscope: the Second Edition, with Considerable Additions and Improvements, Dillon \& Keating, London, 1798.

Kender, S. and Kaminski, M. A.: Modern deep-water agglutinated foraminifera from IODP Expedition 323, Bering Sea: ecological and taxonomic implications, J. Micropalaeontology, https://doi.org/10.1144/jmpaleo2016-026, 2017.

Kennett, J. P.: New Foraminifera from the Ross Sea, Antarctica, Contributions from the Cushman Foundation for Foraminiferal Research, 18, 133-135, 1967.

Kitazato, H., Shirayama, Y., Nakatsuka, T., Fujiwara, S., Shimanaga, M., Kato, Y., Okada, Y., Kanda, J., Yamaoka, A., Masuzawa, T., and Suzuki, K.: Seasonal phytodetritus deposition and responses of bathyal benthic foraminiferal populations in Sagami Bay, Japan: preliminary results from
“Project Sagami 1996-1999”, Mar. Micropaleontol., 40, 135149, https://doi.org/10.1016/s0377-8398(00)00036-0, 2000.

Knight, R.: Apertural characteristics of certain unilocular foraminifera: methods of study, nomenclature and taxonomic significance, J. Micropaleontol., 5, 37-47, 1986.

Lamarck, J. B.: Suite des mémoires sur les fossiles des environs de Paris, Annales du Muséum d'Histoire Naturelle, 5, 105-115, 179-188, 1804.

Lamarck, J. B.: Extrait du course de zoologie du Museum d'Histoire Naturelle, sur les animaux sans vertebres, d'Hautel, Paris, 1812.

Le Coze, F. and Hayward, B.: Lagena striatopunctata Parker \& Jones, 1865, in: World Foraminifera Database, edited by: Hayward, B. W., Cedhagen, T., Kaminski, M., and Gross, O., avaiable at: http://www.marinespecies.org/foraminifera./aphia.php? $\mathrm{p}=$ taxdetails\&id=525593 (last access: 12 July 2017), 2017.

Linke, P. and Lutze, G. F.: Microhabitat preferences of benthic foraminifera - a static concept or a dynamic adaptation to optimize food acquisition, Mar. Micropaleontol., 20, 215-234, https://doi.org/10.1016/0377-8398(93)90034-u, 1993.

Linnaeus, C.: Systema Naturae per Regnia tria Naturae, secundum classes, ordines, genera, species, cum characteribus, differentiis, synonymis, locis, Stockholm, 823 pp., 1758.

Lipps, J. H., DeLaca, T. E., Krebs, W. N., and Stockton, W.: Shallow-water foraminifera studies, Antarctic Peninsula, 19711972, Foraminiferal ecology, Antarctic Peninsula, Antarctic, Journal of the United States, 7, 82-83, 1972.

Loeblich, A. R. and Tappan, H.: Revision of some recent foraminiferal genera, Smithsonian Miscellaneous Collections, 128, 1-37, 1955.

Loeblich, A. R. and Tappan, H.: Suprageneric classification of the Rhizopodea, J. Paleontol., 35, 245-330, 1961.

Loeblich, A. R. and Tappan, H.: Some new proteinaceous and agglutinated genera of Foraminiferida, J. Paleontol., 58, 11581163, 1984.

Loeblich, A. R. and Tappan, H.: Some new and redefined genera and families of Textulariina, Fusulinina, Involutinina and Miliolina (Foraminiferida), J. Foramin. Res., 16, 334-346, 1986.

Loeblich, A. R. and Tappan, H.: Foraminiferal genera and their classification, Van Nostrand Reinhold, New York, 1988.

Loeblich, A. R. and Tappan, H.: Foraminifera of the Sahul Shelf and Timor Sea, Cushman Foundation for Foraminiferal Research Special Publication, 31, 1-661, 1994.

Loubere, P., Meyers, P., and Gary, A.: Benthic foraminiferal microhabitat selection, carbon isotope values, and association with larger animals - a test with Uvigerina peregrina, J. Foramin. Res., 25, 83-95, 1995.

Loubere, P., Jacobsen, B., Klitgaard Kristensen, D., Husum, K., Jernas, P., and Richaud, M.: The structure of benthic environments and the paleochemical record of foraminifera, Deep-Sea Res. Pt I, 58, 535-545, https://doi.org/10.1016/j.dsr.2011.02.011, 2011.

Luo, M., Chen, L. Y., Wang, S. H., Yan, W., Wang, H. B., and Chen, D. F.: Pockmark activity inferred from pore water geochemistry in shallow sediments of the pockmark field in southwestern Xisha Uplift, northwestern South China Sea, Mar. Petrol. Geol., 48, 247-259, https://doi.org/10.1016/j.marpetgeo.2013.08.018, 2013.

Mackensen, A., Grobe, H., Kuhn, G., and Futterer, D. K.: Benthic Foraminiferal Assemblages from the Eastern Weddell Sea Between 68 and $73^{\circ} \mathrm{S}$ - Distribution, Ecology and 
Fossilisation Potential, Mar. Micropaleontol., 16, 241-283, https://doi.org/10.1016/0377-8398(90)90006-8, 1990.

Mackensen, A., Futterer, D. K., Grobe, H., and Schmiedl, G.: Benthic Foraminiferal Assemblages from the Eastern South-Atlantic Polar Front Region Between 35 and $57^{\circ} \mathrm{S}$ - Distribution, Ecology and Fossilization Potential, Mar. Micropaleontol., 22, 33-69, https://doi.org/10.1016/0377-8398(93)90003-g, 1993.

Majewski, W.: Benthic foraminiferal communities: distribution and ecology in Admiralty Bay, King George Island, West Antarctica, Pol. Polar Res., 26, 159-214, 2005.

Majewski, W.: Benthic foraminifera from West Antarctic fiord environments: An overview, Pol. Polar Res., 31, 61-82, https://doi.org/10.4202/ppres.2010.05, 2010.

Majewski, W.: Benthic foraminifera from Pine Island and Ferrero bays, Amundsen Sea, Pol. Polar Res., 34, 169-200, https://doi.org/10.2478/popore-2013-0012, 2013.

Majewski, W. and Anderson, J. B.: Holocene foraminiferal assemblages from Firth of Tay, Antarctic Peninsula: Paleoclimate implications, Mar. Micropaleontol., 73, 135-147, https://doi.org/10.1016/j.marmicro.2009.08.003, 2009.

Marie, P.: La foraminifères de la Craie à Belemnitella mucronata du Bassin de Paris, Mémoires de Museum Nationale d'Histoire Naturelle, 12, 1-296, 1941.

Maync, W.: Critical taxonomic study and nomenclatural revision of the Lituolidae based upon the prototype of the family, Lituola nautiloidea Lamarck 1804, Contributions from the Cushman Foundation for Foraminiferal Research, 3, 35-56, 1952.

McCorkle, D. C. and Emerson, S. R.: The relationship between pore water carbon isotopic composition and bottom water oxygen concentration, Geochim. Cosmochim. Ac., 52, 1169-1178, https://doi.org/10.1016/0016-7037(88)90270-0, 1988.

McCorkle, D. C., Emerson, S. R., and Quay, P. D.: Stable carbon isotopes in marine porewaters, Earth Planet. Sc. Lett., 74, 13-26, https://doi.org/10.1016/0012-821x(85)90162-1, 1985.

McCorkle, D. C., Keigwin, L. D., Corliss, B. H., and Emerson, S. R.: The influence of microhabitats on the carbon isotopic composition of deep-sea benthic foraminifera, Paleoceanography, 5, 161-185, https://doi.org/10.1029/PA005i002p00161, 1990.

McCorkle, D. C., Corliss, B. H., and Farnham, C. A.: Vertical distributions and stable isotopic compositions of live (stained) benthic foraminifera from the North Carolina and California continental margins, Deep-Sea Res. Pt. I, 44, 983-1024, https://doi.org/10.1016/S0967-0637(97)00004-6, 1997.

McCulloch, I.: Qualitative observations on Recent foraminiferal tests with emphasis on the eastern Pacific, University of Southern California, Los Angeles, 1977.

Meredith, M. P., Brandon, M. A., Murphy, E. J., Trathan, P. N., Thorpe, S. E., Bone, D. G., Chernyshkov, P. P., and Sushin, V. A.: Variability in hydrographic conditions to the east and northwest of South Georgia, 1996-2001, J. Marine Syst., 53, 143-167, https://doi.org/10.1016/j.jmarsys.2004.05.005, 2005.

Mikhalevich, V. I.: Systematics and evolution of forminifera in the light of new data on their cytology and ultrastructure, Trudy Zoologicheskogo Instituta Akademiya Nauk SSSR, 94, 42-61, 1980.

Mikhalevich, V. I.: A new classification of the class Astrorhizata, Zoosystematica Rossica, 3, 161-174, 1995.

Mikhalevich, V. I.: The general aspects of the distribution of Antarctic foraminifera, Micropaleon- tology, 50, 179-194, https://doi.org/10.1661/00262803(2004)050[0179:moeoti]2.0.co;2, 2004.

Miklukho-Maklay, A. D.: Upper Palaeozoic of Central Asia, Leningradskiy Universitet, Lenigrad, 1963.

Milam, R. W. and Anderson, J. B.: Distribution and Ecology of Recent Benthonic Foraminifera of the Adelie-George-V Continental-Shelf and Slope, Antarctica, Mar. Micropaleontol., 6, 297-325, 1981.

Montagu, G.: Testacea Britannica or Natural History of British Shells, Marine, Land, and Fresh-Water, Including the Most Minute, J. S. Hollis, Romsey, England, 1803.

Montfort, P. D. d.: Conchyliologie systématique et classification méthodique des coquilles, F. Schoell, Paris, 676 pp., 1808.

Moreman, W. L.: Arenaceous foraminifera from Ordovician and Silurian limestones of Oklahoma, J. Paleontol., 4, 42-59, 1930.

Murphy, E. J., Hofmann, E. E., Watkins, J. L., Johnston, N. M., Pinones, A., Ballerini, T., Hill, S. L., Trathan, P. N., Tarling, G. A., Cavanagh, R. A., Young, E. F., Thorpe, S. E., and Fretwell, P.: Comparison of the structure and function of Southern Ocean regional ecosystems: The Antarctic Peninsula and South Georgia, J. Marine Syst., 109, 22-42, https://doi.org/10.1016/j.jmarsys.2012.03.011, 2013.

Murray, J. W. and Bowser, S. S.: Mortality, protoplasm decay rate, and reliability of staining techniques to recognize "living" foraminifera: A review, J. Foramin. Res., 30, 66-70, https://doi.org/10.2113/0300066, 2000.

Murray, J. W. and Pudsey, C. J.: Living (stained) and dead foraminifera from the newly ice-free Larsen Ice Shelf, Weddell Sea, Antarctica: ecology and taphonomy, Mar. Micropaleontol., 53, 67-81, https://doi.org/10.1016/j.marmicro.2004.04.001, 2004.

Nomaki, H., Heinz, P., Hemleben, C., and Kitazato, H.: Behavior and response of deep-sea benthic foraminifera to freshly supplied organic matter: A laboratory feeding experiment in microcosm environments, J. Foramin. Res., 35, 103-113, https://doi.org/10.2113/35.2.103, 2005.

Ohga, T. and Kitazato, H.: Seasonal changes in bathyal foraminiferal populations in response to the flux of organic matter (Sagami Bay, Japan), Terra Nova, 9, 33-37, https://doi.org/10.1046/j.1365-3121.1997.d01-6.x, 1997.

Parker, F. L.: Foraminiferal distribution in the Long Island Sound - Buzzards Bay area, Bulletin of the Museum of Comparative Zoology, Harvard, 106, 428-473, 1952.

Parker, W. K. and Jones, T. R.: On some foraminifera from the North Atlantic and Arctic Oceans, including Davis Straits and Baffin's Bay, Philos. T. R. Soc., 155, 325-441, 1865.

Parr, W. J.: On Torrresina, a new genus of the foraminifera from eastern Australia, Journal of the Royal Microscopical Society, 64, 129-135, 1947.

Parr, W. J.: Foraminifera, in: Reports B.A.N.Z. Antarctic Research Expedition 1929-1931, 232-392, 1950.

Patterson, R. T. and Richardson, R. H.: A taxonomic revision of the unilocular Foraminifera, J. Foramin. Res., 17, 212-226, 1987.

Pearcey, F. G.: Foraminifera of the Scottish National Antarctic Expedition, T. Roy. Soc. Edin., 49, 991-1044, 1914.

Peck, V. L., Allen, C. S., Kender, S., McClymont, E. L., and Hodgson, D.: Oceanographic variability on the West Antarctic Peninsula during the Holocene and the influence of up- 
per circumpolar deep water, Quaternary Sci. Rev., 119, 54-65, https://doi.org/10.1016/j.quascirev.2015.04.002, 2015.

Piña-Ochoa, E., Høgslund, S., Geslin, E., Cedhagen, T., Revsbech, N. P., Nielsen, L. P., Schweizer, M., Jorissen, F., Rysgaard, S., and Risgaard-Petersen, N.: Widespread occurrence of nitrate storage and denitrification among Foraminifera and Gromiida, P. Natl. Acad. Sci. USA, 107, 1148-1153, https://doi.org/10.1073/pnas.0908440107, 2010.

Puri, H. S.: Contribution to the study of the Miocene of teh Florida panhandle, Bulletin Florida State Geological Survey, 36, 1-345, 1954.

Rauzer-Chernousova, D. M. and Reytlinger, E. A.: On the suprageneric systematics of the Order Hormosinida (Foraminifera), Paleontologicheskiy Zhurnal, 1986, 15-20, 1986.

Ravelo, A. C. and Hillaire-Marcel, C.: The use of oxygen and carbon isotopes of foraminifera in paleoceanography, in: Proxies in Late Cenozoic Paleoceanography, edited by: Hillaire-Marcel, C. and De Vernal, A., Developments in Marine Geology, Elsevier, Amsterdam, 735-764, 2007.

Reuss, A. E.: Uber zwei neue Arten von Foraminiferen aus dem Tegel van Baden und Mollersdorf, in: Bericht uder die Mittheilungen Freunden der Naturwissenschaften in Wien, edited by: Czjzek, J., 50-56, 1849.

Reuss, A. E.: Neues Foraminiferen aus den Schichten des Osterreichischen Tertiarbeckens, Denkschriften der Akademie des Wissenschaften, 1, 365-390, 1850.

Reuss, A. E.: Die Foraminiferen der westphälischen Kreideformation, Sitzungsberichte der mathematisch-naturwissenschaflichen Classe der kaiserlichen Akademie der Wissenschaften, 40, 147238, 1860.

Reuss, A. E.: Entwurf einer systematischen Zusammenstellung der Foraminiferen, Sitzungsberichte der Kaiserlichen Akademie der Wissenschaften in Wien. Mathematicsch-Naturwissenschaftliche Classe, 1861, 355-396, 1862.

Reuss, A. E.: Die Foraminiferen, Anthozoen und Bryozoen des deutschen Septarienthones, Denkschriften der Akademie des Wissenschaften, Wien, 25, 117-214, 1866.

Rhumbler, L.: Entwurf eines naturlichen systems der Thalamophoren, Nachrichten von der Gesellschaft der Wissenschaften zu Gottingen, Math-Physik Klasse, 1895, 51-98, 1895.

Rhumbler, L.: Die Foraminiferen (Thalamophoren) der PlanktonExpedition, Erster Teil, Die allgemein Organizationsverhaltnisse der Foraminiferen, Ergebnisse der Plankton-Expedition der Humboldt-Stiftung Kiel u Liepzig, 3, 1-331, 1911.

Rodrigues, A. R., Eichler, P. P. B., and Eichler, B. B.: Foraminifera in two inlets fed by a tidewater glacier, King George Island, Antarctic Peninsula, J. Foramin. Res., 43, 209-220, 2013.

Saidova, K. M.: Bentosnye Foraminifery rayona kuriloKamchatskogo zheloba (po materianlam 39-go reysa e/s "Vityaz") [Benthic foraminifera in the Kurile-Kamchatka region based on the data of the 39th cruise of the R/V "Vityaz."], Trudy Instituta Okeanologii, 86, 134-161, 1970.

Saidova, K. M.: Bentosniye foraminifery Tikhogo Okeana, P.P. Shirshov Institute of Oceanology, Academy of Sciences of the USSR, Moscow, 1975.

Saidova, K. M.: O sovremennom sostoyanii sistemy nadvidovykh taksonov Kaynozoyskikh bentosnykh foraminifer [On an up-todate system of supraspecific taxonomy of Cenozoic benthonic foraminifera], Akademiya Nauk SSSR, Moscow, 1981.
Sars, M.: Fortsatte bemerkinger over det dyriske livs udbredning i havets dybder, Förhandlinger i Videnskabsselskabet i Kristiania, 1869, 246-275, 1869.

Schilman, B., Almogi-Labin, A., Bar-Matthews, M., and Luz, B.: Late Holocene productivity and hydrographic variability in the eastern Mediterranean inferred from benthic foraminiferal stable isotopes, Paleoceanography, 18, https://doi.org/10.1029/2002pa000813, 2003.

Schmiedl, G., Mitschele, A., Beck, S., Emeis, K. C., Hemleben, C., Schulz, H., Sperling, M., and Weldeab, S.: Benthic foraminiferal record of ecosystem variability in the eastern Mediterranean Sea during times of sapropel S-5 and S-6 deposition, Palaeogeogr. Palaeocl., 190, 139-164, https://doi.org/10.1016/s00310182(02)00603-x, 2003.

Schmiedl, G., Pfeilsticker, M., Hemleben, C., and Mackensen, A.: Environmental and biological effects on the stable isotope composition of recent deep-sea benthic foraminifera, from the western Mediterranean Sea, Mar. Micropaleontol., 51, 129-152, https://doi.org/10.1016/j.marmicro.2003.10.001, 2004.

Schultze, M. J. S.: Über den Organismus der Polythalamien (Foraminiferen), nebst Bemerkungen über die Rhizopoden im allgemeinen, Leipzig, Ingelmann, 1854.

Schulze, F. E.: Rhizopodenstudien. III., Archiv für Mikroskopische Anatomie 11, 94-139, 1875.

Schwager, C.: Saggio di una classificazione dei foraminiferi avuto riguardo alle loro famiglie naturali, Bolletino R. Comitato Geologico d'Italia, 7, 475-485, 1876.

Schwager, C.: Quadro del proposto sistema di classificazione dei foraminiferi con guscio, Bolletino R. Comitato Geologico d'Italia, 8, 18-27, 1877.

Seguenza, G.: Dei terreni Terziarii del distretto di Messina: Parte II - Descrizione dei foraminiferi monotalamici delle marne Mioceniche del distretto di Messina, T. Capra, Messina, 1862.

Setoyama, E. and Kaminski, M. A.: Neogene benthic foraminifera from the southern Bering Sea (IODP Expedition 323), Palaeontologia Electronica, 18.2.38A, 1-30, 2015.

Shchedrina, Z. G.: O nekotorykh izmeneniyakh v sisteme semeytv Astrorhizidae i Reophacidae (Foraminifera) [On some changes in the systematics of the families Astrorhizidae and Reopacidae (Foraminifera)], Voprosy Mikropaleontologii, 11, 157-170, 1969.

Silvestri, A.: Lo stipite della Elissoforme e le sue affinita, Memorie della Pontificia Accademia della Scienze, Nouvi Lincei, 6, 231270, 1923.

Silvestri, O.: Saggio di studi sulla fauna microscopia fossile appartenente al terreno subappenino italiano. Mem. I - monografia delle Nodosarie, Academia Gioenia Scienze Naturali Catania 7, 108, 1872.

Stefanoudis, P. V., Bett, B. J., and Gooday, A. J.: Relationship between "live" and dead benthic foraminiferal assemblages in the abyssal NE Atlantic, Deep-Sea Res. Pt. I, 121, 190-201, https://doi.org/10.1016/j.dsr.2017.01.014, 2017.

Sweetman, A. K., Sommer, S., Pfannkuche, O., and Witte, U.: Retarded response by macrofauna-size foraminifera to phytodetritus in a deep Norwegian fjord, J. Foramin. Res., 39, 15-22, https://doi.org/10.2113/gsjfr.39.1.15, 2009.

Tachikawa, K. and Elderfield, H.: Microhabitat effects on $\mathrm{Cd} / \mathrm{Ca}$ and $\delta^{13} \mathrm{C}$ of benthic foraminifera, Earth Planet. Sc. Lett., 
202, 607-624, https://doi.org/10.1016/S0012-821X(02)00796-3, 2002.

Thalmann, H. E.: Nomenclator (Um- und Neubennungen) zu den Tafeln 1 bis 115 in H. B. Brady's Werk uber die Foraminferen der Challenger-Expedition, London 1884, Eclogae Geologicae Helvetiae, 25, 293-312, 1932.

Theodor, M., Schmiedl, G., and Mackensen, A.: Stable isotope composition of deep-sea benthic foraminifera under contrasting trophic conditions in the western Mediterranean Sea, Mar. Micropaleontol., 124, 16-28, https://doi.org/10.1016/j.marmicro.2016.02.001, 2016.

Thorpe, S. E., Heywood, K. J., Brandon, M. A., and Stevens, D. P.: Variability of the southern Antarctic Circumpolar Current front north of South Georgia, J. Marine Syst., 37, 87-105, https://doi.org/10.1016/s0924-7963(02)00197-5, 2002.

Uchio, T.: Ecology of living benthonic foraminifera from the San Diego, California area, Special Publications Cushman Laboratory for Foraminiferal Research, 5, 1-72, 1960.

Uchio, T.: Influence of the River Shinano on foraminifera and sediment grain size distribution, Publications of the Seto Marine Biological Laboratory, 10, 363-392, 1962.

Van Marle, L.: Eastern Indonesia Late Cenozoic smaller benthic foraminifera, Verhandeling Koninklijke Nederlandse Akademie van Wetenschappen, Afdeling Antuurkunde, Eerste Reeks, 34, 1-328, 1991.

Violanti, D.: Taxonomy and distribution of recent benthic foraminifers from Terra Nova Bay (Ross Sea, Antarctica), oceanographic campaign 1987/1988, Palaeontographica Italica, 83, 25-71, 1996.

Voloshinova, N. A.: Progress in micropalaeontology in the work of studying the inner structure of Foraminifera, Trudy Pervogo Seminara po Mikrofaune, 48-87, 1960.
Wang, F., Gao, M., Liu, J., Pei, S., Li, C., Mei, X., and Yang, S.: Distribution and environmental significance of live and dead benthic foraminiferal assemblages in surface sediments of Laizhou Bay, Bohai Sea, Mar. Micropaleontol., 123, 1-14, https://doi.org/10.1016/j.marmicro.2015.12.006, 2016.

Wedekind, P. R.: Einfuhrung in die Grundlagen der historischen Geologie. Band II. Mikrobiostratigraphie der Korallen- und Foraminiferenzeit, Ferdinand Enke, Stuttgart, 1937.

Weldeab, S., Arce, A., and Kasten, S.: Mg / Ca-Delta CO3pore2(water)-temperature calibration for Globobulimina spp.: A sensitive paleothermometer for deep-sea temperature reconstruction, Earth Planet. Sc. Lett., 438, 95-102, https://doi.org/10.1016/j.epsl.2016.01.009, 2016.

Wiesner, H.: Die Foraminiferen der Deutschen Südpolar Expedition 1901-1903. Deutschen Südpolar Expedition, Berlin (Zoology), 20, 53-165, 1931.

Williamson, W. C.: On the Recent British species of the genus Lagena, Annals and Magazine of Natural History, 2, 1-20, 1848.

Witte, U., Wenzhofer, F., Sommer, S., Boetius, A., Heinz, P., Aberle, N., Sand, M., Cremer, A., Abraham, W. R., Jorgensen, B. B., and Pfannkuche, O.: In situ experimental evidence of the fate of a phytodetritus pulse at the abyssal sea floor, Nature, 424, 763766, 2003.

Zahn, R., Winn, K., and Sarnthein, M.: Benthic foraminiferal $\delta^{13} \mathrm{C}$ and accumulation rates of organic carbon: Uvigerina peregrina group and Cibicidoides wuellerstorfi, Paleoceanography, 1, 2742, 1986.

Zheng, S. and Fu, Z.: Fauna Sinica, Phylum Granuloreticulosa, Class Foraminiferea, Agglutinated Foraminifera, Science Press, Beijing, 2001. 